UNIVERSIDADE DE SÃO PAULO

ESCOLA DE ENFERMAGEM DE RIBEIRÃO PRETO

ALINE DA SILVA OLIVEIRA

TRATAMENTO DE ESGOTO PELO SISTEMA DE LODOS ATIVADOS NO MUNICÍPIO DE RIBEIRÃO PRETO, SP: Avaliação da remoção de metais pesados 
ALINE DA SILVA OLIVEIRA

\title{
TRATAMENTO DE ESGOTO PELO SISTEMA DE LODOS ATIVADOS NO MUNICÍPIO DE RIBEIRÃO PRETO, SP: Avaliação da remoção de metais pesados
}

\author{
Dissertação apresentada à Escola de \\ Enfermagem de Ribeirão Preto da \\ Universidade de São Paulo para obtenção do \\ Título de Mestre, pelo Programa de Pós- \\ Graduação em Enfermagem em Saúde \\ Pública do Departamento Enfermagem \\ Materno-Infantil e Saúde Pública.
}

Área de Concentração: Saúde Ambiental Orientadora: Prof ${ }^{a}$ Dr $^{a}$ Susana Inés Segura Muñoz

Ribeirão Preto 
AUTORIZO A REPRODUÇÃO E DIVULGAÇÃO TOTAL OU PARCIAL DESTE TRABALHO, POR QUALQUER MEIO CONVENCIONAL OU ELETRÔNICO, PARA FINS DE ESTUDO E PESQUISA, DESDE QUE CITADA A FONTE.

Catalogação na Publicação

Serviço de Documentação da Enfermagem

Escola de Enfermagem de Ribeirão Preto da Universidade de São Paulo

Oliveira, Aline da Silva

Tratamento de esgoto pelo sistema de lodos ativados no município de Ribeirão Preto, SP: avaliação da remoção de metais pesados / Aline da Silva Oliveira; orientadora Susana Inés Segura Muñoz. -- Ribeirão Preto, 2006.

$172 \mathrm{f}$.

Dissertação (Mestrado - Programa de Pós-Graduação em Enfermagem em Saúde Pública. Área de Concentração: Saúde Ambiental) - Escola de Enfermagem de Ribeirão Preto da Universidade de São Paulo.

1. Metais Pesados. 2. Tratamento de esgoto. 3. efluentes.

4. Lodos ativados. 5. Ribeirão Preto. 


\section{FOLHA DE APROVAÇÃO}

\section{Aline da Silva Oliveira}

Dissertação apresentada à Escola de Enfermagem de Ribeirão Preto da Universidade de São Paulo para obtenção do Título de Mestre.

Área de Concentração: Saúde Ambiental

Aprovado em:

Banca Examinadora

Prof. Dr.

Instituição:

Assinatura:

Prof. Dr.

Instituição: Assinatura:

Prof. Dr.

Instituição: Assinatura: 


\section{DEDICATÓRIA}

Aos meus pais Artur e Elenice, meu irmão Artur Filho e meu noivo Luciano, com amor, gratidão por sua compreensão, carinho, presença e incansável apoio ao longo do período de elaboração deste

trabalho. 


\section{AGRADECIMENTOS}

À Prof. Dra. Susana Inés Segura Muñoz, pela orientação, amizade, admiração, dedicação, contribuindo para meu crescimento científico e intelectual. Por ter acreditado em mim, motivo de muito orgulho e muita responsabilidade em ser sua primeira orientanda.

À Profa. Dra. Ângela Maria Magosso Takayanagui, pela atenção e sugestões oferecidas, além da amizade, que me foram de grande importância.

Ao Prof. Dr. Valdir Schalch da Escola de Engenharia e Hidráulica de Saneamento de São Carlos pela sua atenção, disposição e sugestões.

Á Escola de Enfermagem de Ribeirão Preto da Universidade de São Paulo, pela oportunidade de realização do curso de mestrado.

Á Fundação de Amparo à Pesquisa do Estado de São Paulo pela concessão da bolsa de mestrado e pelo apoio financeiro para a realização desta pesquisa.

À Biomédica Tânia Maria Beltramini Trevilato, do Setor de Metais do Laboratório de Pediatria do Hospital das Clínicas da Faculdade de Medicina de Ribeirão Preto, pela pronta disposição, apoio e infra estrutura disponibilizada na colaboração e intensa ajuda na realização de análises de metais.

Ao Engenheiro Carlos Roberto Ferreira, Engenheiro responsável pela operação da ETE- Ribeirão Preto, pela confiança e apoio para o desenvolvimento deste estudo. E a engenheira Química Karina Carregari pelo apoio na coleta das amostras.

A grande amiga Meire $\mathcal{N}$ ikaido por perder suas férias e estar junto comigo colaborando todos os dias fazendo a coleta. E minha grande amiga, a minha orientadora, que me ajudou muito nos dias em que não pude ir.

Ao Prof. Dr. Jose Domingo e a Prof. Dra. Ana Bócio do Laboratório de Toxicologia e Salud Médio Ambiental de la Universidad Rovira y Virgili, Réus, Tarragona, na Enpanha pela disposição e colaboração nas dosagens e análise das amostras de lodo. 
Ao Engo. Paulo Mano pela colaboração na demarcação geográfica dos pontos de coleta da ETE -

Ribeirão Preto.

Á amiga e conselheira Márcia, do Setor de Metais do HCFMRP/USP juntamente com as aprimorandas da FUNDAP, Ana Carolina e Isis pelo incentivo, colaboração e grande amizade.

As minhas amigas demais de outros laboratórios da Pediatria, pela ajuda, apoio e colaboração nas etapas deste estudo, Adelina, Ivone, Betty, Sylvia e Pedro.

Ao técnico Gilberto Padovan, do Laboratório de Sutrição da Faculdade Medicina da Universidade de São Paulo pela valiosa colaboração na liofilização das amostras de lodo.

Aos professores da EERP/USP, a todos os docentes do Departamento de Enfermagem MaternoInfantil e Saúde Pública, pelo conhecimento compartilhado.

À Adriana, OCânia, Andréa e Augusto do Departamento MISP da EERP/USP por toda a colaboração.

Às funcionárias da Seção de Pós-Graduação da EERP/USP pela colaboração e apoio.

Às 6olsistas do Laboratório de Saúde Ambiental de EERP/USP, Marina, Kamila, Pricilla, Geórgia, Tatiana, Gabriela, Jamyle pela amizade e trabalhos juntas. E em especial a grande amiga Rose pelo seu carinho e atenção para comigo.

Aos guardas da EERP/USP pela sua atenção e vigilância.

Às amigas e os amigos pós-graduandos, grande companheiros dos momentos tristes e alegres, das nossas festas, chimarrões, festas das bruxas, festas juninas e outras, pelos momentos compartilhados, serão eternamente guardadas no meu coração, Anne, Eliane, Marilú, Rosani, Luciana, Elisa, Nelma e Alessandro, Miquelina e Leandro, Juliana Monteiro, Juliana Bueno, Ricardo e Leila.

Em agradecimento especial para Anne Marie, conselheira e colaboradora nos artigos, no projeto, nas correções e traduções. E Rosani e $\mathcal{N}$ elma pela contribuição da esquematização da aula. 
RESUMO 


\section{RESUMO}

Oliveira, A.S. Tratamento de esgoto pelo sistema de lodos ativados no município de Ribeirão Preto, SP: avaliação da remoção de metais pesados. 2006. 172f. Dissertação (Mestrado) - Escola de Enfermagem de Ribeirão Preto, Universidade de São Paulo, Ribeirão Preto.

Os sistemas de tratamento de esgotos sanitários são considerados como requisitos básicos de infra-estrutura para as sociedades urbanas, pois possibilitam o controle e a prevenção de muitas doenças, gerando condições de higiene que promovem a saúde pública. Considerando os elementos constituintes dos efluentes urbanos e industriais, além da carga microbiológica, podem conter diversos poluentes químicos que afetam a saúde humana. Dentre os constituintes químicos, destacam-se os metais pesados que, se não devidamente removidos durante o processo de tratamento, podem causar uma poluição significativa no corpo receptor, representando um risco para a saúde humana e ambiental. Em Ribeirão Preto SP há em funcionamento duas estações de tratamento de esgotos (ETE) sendo a ETE-Caiçara, desde o ano de 2000 e a ETE-Ribeirão Preto, desde 2002. Este estudo teve como objetivo avaliar os níveis de metais pesados em efluentes urbanos, antes e após o tratamento de esgoto pelo sistema de lodos ativados da ETE-Ribeirão Preto. Visou também avaliar os níveis de metais pesados no lodo formado durante o tratamento de esgoto pelo sistema de lodos ativados, considerando sua possível utilização para fins agrícolas. No esgoto bruto e tratado foram analisados os seguintes metais: $\mathrm{Cd}, \mathrm{Cr}, \mathrm{Cu}, \mathrm{Hg}, \mathrm{Mn}, \mathrm{Pb}$ e $\mathrm{Zn}$ utilizando técnicas de espectrofotometria, de acordo com o tipo de metal, como: Espectrofometria de Absorção Atômica acoplado a Forno de Grafite (EAA-FG), Espectrofotometria de Absorção Atômica com Geração de Hidreto (EAA-VGA) e Espectrofotometria de Absorção Atômica de Chama (EAA-Chama). No lodo foram analisados os seguintes metais: As, Be, $\mathrm{Cd}, \mathrm{Cr}, \mathrm{Cu}, \mathrm{Fe}, \mathrm{Hg}$, $\mathrm{Mn}, \mathrm{Ni}, \mathrm{Pb}, \mathrm{Sn}, \mathrm{TI}, \mathrm{V}$ e Zn por Espectroscopia com Plasma Induzido-Espectroscopia de Massas (ICP-MS), Espectroscopia com Plasma Induzido-Espectroscopia Óptico (ICP-OES) e Espectrofometria de Absorção Atômica acoplado a Forno de Grafite (EAA-FG). Com os dados obtidos verificou-se que os níveis de metais pesados presentes nas amostras de esgoto estão dentro dos valores estabelecidos pela Resolução do Conselho Nacional do Meio Ambiente (CONAMA) $n^{0}$. 357/2005 que estabelece as condições e padrões de lançamento de efluentes. Observou-se também que a remoção de metais foram muito variáveis para os diferentes metais. E as concentrações do lodo analisadas apresentaram níveis dentro dos valores estabelecidos para lodo de uso agrícola no Estado de São Paulo (CETESB, 2001). Este estudo evidencia a importância e a função de uma ETE, que é tratar os esgotos que possam causar impactos ambientais nos corpos de água que irão receber esses efluentes, e também a possível disponibilização do lodo para a agricultura, considerando que as legislações estão sendo cumpridas e apresentando, assim, informações às autoridades responsáveis pelo tratamento de esgoto do município de Ribeirão Preto-SP.

Palavras-chave: Metais pesados, esgoto, lodo, tratamento de esgoto, Ribeirão Preto. 
ABSTRACT 


\begin{abstract}
Oliveira, A.S. Sewage treatment through the activated sludge system in Ribeirão Preto, SP: evaluation of heavy metal removal.. 2006. 172p. Thesis (Master’s) - University of São Paulo at Ribeirão Preto College of Nursing, Ribeirão Preto.
\end{abstract}

Sewage treatment systems are considered basic infrastructural requisites for urban societies, as they allow for the control and prevention of many diseases and create hygiene conditions that promote public health. Urban and industrial effluents not only carry a microbiological load, but their constituent elements can contain various kinds of chemical pollutants that affect human health. Chemical elements include heavy metals which, if removed inappropriately during the treatment process, can cause significant pollution in the receiving body and represent a risk for human and environmental health. In Ribeirão Preto SP, Brazil, there are two sewage treatment stations (ETE), one of which is ETE-Caiçara, functioning since 2000, and the other ETE-Ribeirão Preto, since 2002. This study aimed to evaluate heavy metal levels in urban effluents before and after treatment by means of the Activated Sludge System at the ETE-Ribeirão Preto, as well as to evaluate heavy metal levels in the sludge formed during sewage treatment through the activated sludge, considering its potential use for agricultural purposes. We analyzed the following metals in raw and treated wastewater: $\mathrm{Cd}, \mathrm{Cr}, \mathrm{Cu}, \mathrm{Hg}, \mathrm{Mn}, \mathrm{Pb}$ and $\mathrm{Zn}$, using Graphite Furnace Atomic Absorption Spectrophotometry (AAS-GF), Atomic Absorption Spectrophotometry with Hydride Generation (AAS-HG) and Flame-Atomic Absorption Spectrophotometry (AAS-Flame). In the sludge, we analyzed the following metals: As, Be, Cd, Cr, Cu, Fe, Hg, Mn, Ni, Pb, Sn, TI, $\mathrm{V}$ and Zn, using Inductively Coupled Plasma Mass Spectroscopy (ICP-MS), Inductively Coupled Optical Emissions Spectroscopy (ICP-OES) and Graphite Furnace Atomic Absorption Spectrophotometry (AAS-GF). The obtained data revealed that the heavy metal levels present in the wastewater samples remain within the values determined by Resolution No. 357/2005, which establishes effluent emission conditions and norms. Furthermore, we observed great variations in the removal of different kinds of metals. Metal values recorded for sludge were within the maximum permitted levels established by the Environmental Sanitation Company (CETESB), São Paulo, Brazil for agricultural use of sludge. This study evidences the importance and the function of an ETE, that is, to treat wastewater that can cause environmental impacts in the water bodies that will receive these effluents, as well as to make available sludge for agricultural use, guaranteeing that legislation is being complied with and, hence, producing information for the authorities responsible for sewage treatment in Ribeirão Preto-SP.

Keywords: Heavy metals, wastewater, sludge, sewage treatment; Ribeirão Preto. 
RESUMEN 


\section{RESUMEN}

Oliveira, A.S. Tratamiento de aguas residuales por el sistema de lodos activados en el municipio de Ribeirão Preto, SP: evaluación de la remoción de metales pesados. 2006. 172h. Disertación (Maestría) - Escuela de Enfermería de Ribeirão Preto, Universidad de São Paulo, Ribeirão Preto.

Los sistemas de tratamiento de aguas residuales son considerados como requisitos básicos de infraestructura para las sociedades urbanas, pues posibilitan el control y la prevención de muchas enfermedades y generan condiciones de higiene que promueven la salud pública. Los efluentes líquidos urbanos e industriales, además de una carga microbiológica, pueden contener diversos contaminantes químicos que afectan la salud humana. Entre los constituyentes químicos se destacan los metales pesados que, si no debidamente removidos durante el proceso de tratamiento, pueden causar una polución significativa en el cuerpo receptor, representando un riesgo para la salud humana y ambiental. En Ribeirão Preto - SP están en funcionamiento dos estaciones de tratamiento de aguas residuales (ETE): la ETE-Caiçara desde el año de 2000, y la ETE-Ribeirão Preto, que inició su funcionamiento en 2002. Este estudio tuvo como objetivo evaluar los niveles de metales pesados en efluentes urbanos antes y después del tratamiento de aguas residuales por el Sistema de Lodos Activados de la ETE-Ribeirão Preto, y también evaluar los niveles de metales pesados en el lodo formado durante el tratamiento de aguas residuales por el sistema de lodos activados, considerando su potencial utilización con fines agrícolas. En el lodo bruto y tratado fueron analizados los siguientes metales: $\mathrm{Cd}, \mathrm{Pb}, \mathrm{Cr}, \mathrm{Cu}, \mathrm{Mn}, \mathrm{Hg}$ y $\mathrm{Zn}$ por Espectrofotometría de Absorción Atómica-Horno de Grafito (EAA-HG), Espectrofotometría de Absorción Atómica con generador de hidruros (EAA-Hidruros) y Espectrofotometría de Absorción Atómica con llama (EAA-Llama). En el lodo fueron analizados: As, Be, Cd, Cr, $\mathrm{Cu}, \mathrm{Fe}, \mathrm{Hg}, \mathrm{Mn}, \mathrm{Ni}, \mathrm{Pb}, \mathrm{Sn}, \mathrm{TI}, \mathrm{V}$ y Zn por Espectroscopía de Masas con Plasma Acoplado Inductivamente (ICP-MS), Espectroscopía de Emisión Óptica con Fuente de Plasma Acoplada Inductivamente (ICP-OES) y Espectrofotometría de Absorción Atómica-Horno de Grafito (EAA-HG). Con los datos obtenidos se verificó que los niveles de metales presentes en las muestras de aguas residuales están dentro de los valores determinados por la Resolución No. 357/2005 que establece las condiciones y normas de lanzamiento de efluentes. También se observó grandes variaciones en la remoción de los diferentes metales. Las concentraciones en el lodo presentaron niveles dentro de los valores establecidos para lodo de uso agrícola en el Estado de São Paulo por la CETESB (2001). Este estudio evidencia la importancia y la función de una ETE, que es tratar los efluentes que pueden causar impactos ambientales en los cuerpos de agua que irán a recibir esos efluentes, y también disponibilizar el lodo para la agricultura, pudiendo garantizar el cumplimiento de las legislaciones y, así, generando información a las autoridades responsables por el tratamiento de efluentes del municipio de Ribeirão Preto-SP y región.

Palabras clave: Metales pesados, aguas residuales, tratamiento de efluentes, Ribeirão Preto. 
LISTA DE FIGURAS 


\section{LISTA DE FIGURAS}

Figura 1 Visão de saúde agrupadas em quatro categorias.................................. 38

Figura 2 Esquema das etapas do funcionamento de uma estação de tratamento

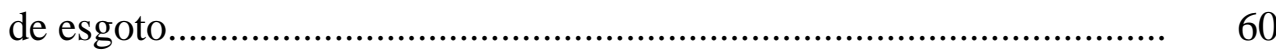

Figura 3 Bactérias, protozoários e micrometazoários encontrados no sistema de lodos ativados..............................................................................

Figura 4 Estação de tratamento de esgoto Caiçara.............................................. 86

Figura 5 Etapas da estação de tratamento de esgoto por lodos ativados de Ribeirão Preto............................................................................. 88

Figura 6 Poço de grossos da ETE-Ribeirão Preto.............................................. 89

Figura 7 Vista parcial do desarenador e desengordurador da ETE-Ribeirão

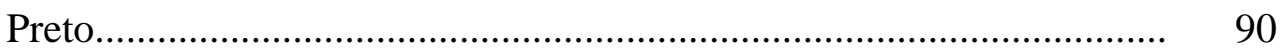

Figura 8 Vista parcial dos decantadores primários da ETE-Ribeirão Preto........ 91

Figura 9 Vistas parciais dos reatores biológicos............................................... 91

Figura 10 Decantadores secundários da ETE-Ribeirão Preto.............................. 92

Figura 11 Lodo desidratado da ETE-Ribeirão Preto............................................. 93

Figura 12 Câmara de cloração da ETE-Ribeirão Preto.......................................... 94

Figura 13 Fonte de saída da ETE-Ribeirão Preto.................................................... 94

Figura 14 Localização da ETE-Ribeirão Preto....................................................... 101

Figura 15 Coleta de esgoto bruto no poço de grossos, na chegada da ETERibeirão Preto-SP, de 28/06 a 06/08 de 2004...................................... 103

Figura 16 Coleta de esgoto tratado, na Fonte de saída da ETE-Ribeirão Preto, de 28/06 a 06/08 de 2004................................................................. 103

Figura 17 Local de coleta de lodo desidratado da ETE- Ribeirão Preto de 28/06 a $06 / 08$ de 2004 .

Figura 18 Digestão das amostras de lodo em ácido nítrico a 65\%, em bombas de teflon, por 16 horas.

Figura 19 Filtração e diluição das amostras uma vez digeridas, preparação das amostras para leitura de metais pesados 
Figura 20 Espectrofotômetro de Absorção Atômica com Forno de Grafite (EAA-FG) e com Gerador de Hidretos e Chama (EAA/VGA / EAAChama), setor de metais do laboratório de pediatria do Hospital das Clínicas da FMRP-USP

Figura 21 Variações da concentração de metais na entrada e saída do esgoto da ETE-Ribeirão Preto, 2004.

Figura 22 Porcentagem de remoção dos níveis médios da entrada e saída da ETE-Ribeirão Preto-SP

Figura 23 Variações das concentrações de metais pesados nas amostras de lodo, coletadas de junho a agosto de 2004 
LISTA DE TABELAS 


\section{LISTA DE TABELAS}

Tabela 1 Evolução da cobertura de água e esgoto no Brasil, 1970-1991........... 48

Tabela 2 Coberturas de redes de abastecimento de água e esgoto no Brasil, na situação urbana, no ano 2000

Tabela 3 Coleta e tratamento de esgoto nos municípios Brasileiros em 2002

Tabela 4 Estimativa da eficiência esperada nos diversos níveis de tratamento incorporados numa ETE.

Tabela 5 Algumas características de funcionamento da ETE-Ribeirão Preto, em 2005

Tabela 6 Concentração de $\mathrm{Mn}, \mathrm{Cr}, \mathrm{Zn}, \mathrm{Cu}, \mathrm{Cd}$ e Pb na amostra certificante S129 com seus respectivos valores esperados em mg/kg.

Tabela 7 Limitações de descarga para estações de tratamento de esgoto estabelecidas pelo artigo 18 e 21 do CONAMA 20/86 e 357/05, para os traços metálicos.

Tabela 8 Concentração média de metais nas amostras de esgoto, coletadas no momento da entrada do efluente bruto na ETE-Ribeirão Preto, SP, em 2004.

Tabela 9 Concentração média de metais nas amostras de esgoto coletadas no local da saída do esgoto tratado da ETE-Ribeirão Preto,SP, em 2004..

Tabela 10 Recomendações internacionais de valores máximos permitidos de metais pesados no esgoto tratado para descarga nos rios e solos (ug/L), em diferentes países, segundo a fonte de informação.

Tabela 11 Quadro comparativo dos padrões dos níveis de metais de corpos de água pertencentes à Classe 2 e Classe 4 da Resolução CONAMA 357/05 e os valores médios obtidos de esgoto tratado analisados na presente pesquisa, 2004.

Tabela 12 Percentual da remoção de metais no esgoto não tratado e tratado de várias ETEs, segundo alguns estudos na literatura.

Tabela 13 Valores médios diários do nível do pH e da temperatura do esgoto bruto da ETE-Ribeirão Preto, em 2004 
Tabela 14 Concentração de metais nas amostras coletadas do lodo da ETERibeirão Preto(mg/kg).....

Tabela 15 Concentração de metais nas amostras coletadas do lodo da ETERibeirão Preto(mg/kg).......

Tabela 16 Concentração de metais nas amostras de lodo coletadas na ETE-RP, 2004, expressa em mg/kg.

Tabela 17 Recomendações internacionais de valores máximos permitidos de metais pesados no lodo de esgoto para uso na agricultura (mg/kg), de acordo com suas referidas fontes..

Tabela 18 Concentrações de valores máximos de metais pesados no lodo de esgoto de várias ETEs (mg/kg). 


\section{LISTA DE SIGLAS}

ABNT Associação Brasileira de Normas Técnicas

APHA American Public Health Association

ASSEMAE Associação Nacional dos Serviços Municipais de Água e Esgoto

ATSDR Agency for Toxic Substances and Disease Registry

CASAN Companhia Catarinense de Águas e Saneamento

CBVA Curso Básico de Vigilância em Saúde

CDCC Centro de Divulgação Científica e Cultural de São Carlos

CEPIS Centro Panamericano de Ingeniería Sanitaria y Ciencias del Ambiente

CETESB Companhia de Tecnologia de Saneamento Ambiental

CNS Conferência Nacional de Saneamento

CODERP Portal da Cidade de Ribeirão Preto

CONAMA Conselho Nacional do Meio Ambiente

COPLADES Construção do Plano Diretor de Esgotos

DAE Departamento de Água e Esgoto

DAERP Departamento de Água e Esgotos de Ribeirão Preto

DAET Departamento de Água, Esgotos e Telefonia

EMBASA Empresa Baiana de Saneamento

EMBRAPA Empresa Brasileira de Pesquisa Agropecuária

ETE Estação de Tratamento de Esgoto

ETEs Estações de Tratamento de Esgotos

ETE-RP Estação de Tratamento de Esgoto de Ribeirão Preto

FGTS Fundação de Garantia por Tempo de Serviço

FUNASA Fundação Nacional de Saúde

HCFMRP Hospital das Clínicas da Faculdade de Medicina de Ribeirão Preto

HIBRACE Plano Diretor de Obras de Aproveitamento Múltiplos dos Recursos Hídricos da Bacia do Alto Tietê

HSDB Hazardous Substances Data Bank

IBGE Instituto Brasileiro de Geografia e Estatística

IF/UFRJ Instituto de Física da Universidade Federal do Rio de Janeiro

ILO International Labour Organization 
LE Lodo de Esgoto

LP Laboratório de Pediatria

MPO Ministério de Planejamento e Orçamento

OECD Organization for Economic Cooperation and Development

PALP Plano de Ação de Longo Prazo

PLANASA Plano Nacional de Saneamento

PLC Projeto Lei do Congresso

PLS Projeto Lei do Senado

PMSP Prefeitura do Município de São Paulo

PMSS Projeto de Modernização do Setor de Saneamento

PNSB Pesquisa Nacional de Saneamento

RAE Repartição de Águas e Esgotos

RMSP Região Metropolitana de São Paulo

SABESP Companhia de Saneamento Básico do Estado de São Paulo

SAE Serviço de Água e Esgoto

SANEPAR Companhia de Saneamento do Paraná

SANESUL Empresa de Saneamento do Mato Grosso do Sul

SNIS Sistema Nacional de Informações em Saneamento

WHO World Health Organization 


\section{LISTA DE SÍMBOLOS}

As

$\begin{array}{ll}\text { EAA-Chama } & \text { Espectrofotômetro de Absorção Atômica com Chama } \\ \text { EAA-FG } & \text { Espectrofotômetro de Absorção Atômica com Forno de Grafite } \\ \text { EAA-VGA } & \text { Espectrofotômetro de Absorção Atômica com Gerador de Hidretos } \\ \mathrm{Be} & \text { Berílio } \\ \mathrm{Cd} & \text { Cádmio } \\ \mathrm{Cr} & \text { Cromo } \\ \mathrm{Cu} & \text { Cobre } \\ \mathrm{Fe} & \text { Ferro } \\ \mathrm{Hg} & \text { Mercúrio } \\ \mathrm{ICP}-\mathrm{MS} & \text { Espectroscopia com Plasma Induzido- Espectroscopia de Massas } \\ \mathrm{ICP}-\mathrm{OES} & \text { Espectroscopia com Plasma Induzido- Espectroscopia Óptico } \\ \mathrm{Mn} & \text { Manganês } \\ \mathrm{Ni} & \text { Níquel } \\ \mathrm{Pb} & \text { Chumbo } \\ \mathrm{St} & \text { Estanho } \\ \mathrm{Tl} & \text { Tálio } \\ \mathrm{V} & \text { Vanádio } \\ \mathrm{Zn} & \text { Zinco } \\ \end{array}$

Arsênio

Espectrofotômetro de Absorção Atômica com Chama 
SUMÁRIO 


\section{SUMÁRIO}

\section{RESUMO}

ABSTRACT

RESUMEN

LISTA DE FIGURAS

LISTA DE TABELAS

LISTA DE SIGLAS

LISTA DE SÍMBOLOS

APRESENTAÇÃO

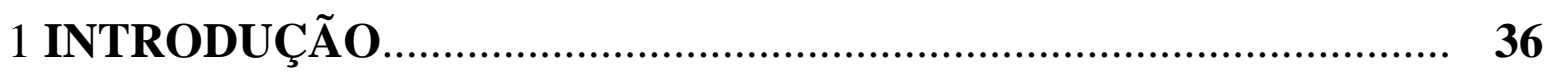

1.1 Saúde pública e saneamento.................................................................................. 37

1.2 Saneamento e sistemas de esgotos sanitários............................................................... 43

1.2.1 Histórico dos sistemas de esgotamento sanitário no mundo, no Brasil e no Estado

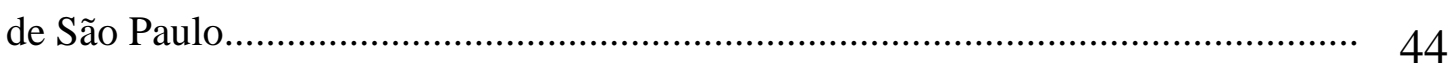

1.3 Tecnologias para tratamento de esgotos sanitários.................................................... 57

1.4 Esgoto sanitário e metais pesados......................................................................... 61

1.5 Sistema de tratamento de esgoto por lodos ativados................................................... 75

Sistemas de lodos ativados convencional.................................................................. $\quad 78$

Sistema de lodos ativados por aeração prolongada (fluxo contínuo)........................... 78

Sistema de lodos ativados de fluxo intermitente (batelada)......................................... 79

1.6 Lodo de esgoto: caracterização e destinação.............................................................. 79

1.7 Sistemas de esgotamento sanitário no município de Ribeirão Preto........................... 85

a. Estação de tratamento de esgoto Ribeirão Preto - ETE Ribeirão Preto......................... 87

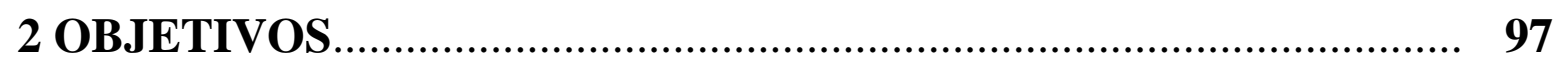

2.1 Objetivo geral............................................................................................ 97

2.1.Objetivos específicos........................................................................................... 97 
3 MATERIAIS E MÉTODOS........................................................... 99

3.1. Local de estudo................................................................................................. 99

3.2. Coleta de amostras............................................................................................ 102

3.3. Leitura de $\mathrm{pH}$ e temperatura......................................................................... 104

3.4. Preparação das amostras para dosagem de metais pesados...................................... 105

3.5. Dosagens de metais no esgoto bruto e tratado.............................................................. 106

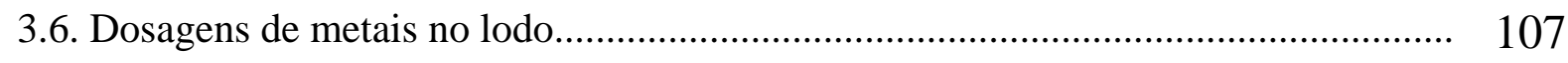

3.7. Curva analítica............................................................................................... 108

3.8. Validação dos métodos......................................................................................... 108

3.9. Análise dos resultados....................................................................................... 109

4 RESULTADOS E DISCUSSÃO …............................................... 112

4.1 Esgoto bruto e tratado..................................................................................... 112

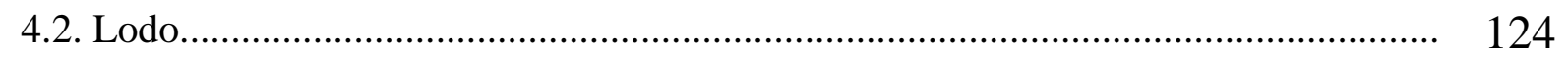

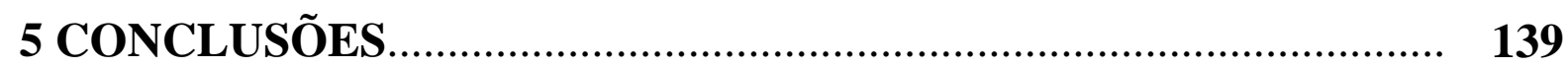

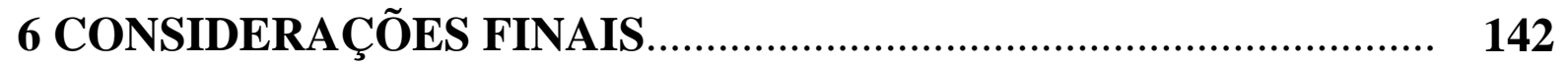

REFERÊNCIAS....................................................................... 145

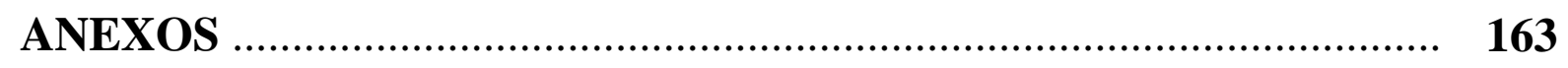

Anexo A - Autorização da empresa Ambient - Serviços Ambientais de Ribeirão Preto S/A

Anexo B - Projeto Cadastral apresentando a localização dos pontos de coleta

Anexo C - Decreto no 10755 de 22/11/77 da CETESB que dispõe o enquadramento dos corpos de água e receptores no Estado de São Paulo, especificamente do córrego Ribeirão Preto-SP 


\section{APRESENTAÇÃO}

A realização desta pesquisa iniciou-se da parceria do Laboratório de Saúde Ambiental da Escola de Enfermagem de Ribeirão Preto/USP com o Setor de Metais do Laboratório de Pediatria e Puericultura do Hospital das Clínicas da Faculdade de Medicina de Ribeirão Preto/USP.

O presente estudo é sobre o Tratamento de Esgoto pelo Sistema de lodos ativados no município de Ribeirão Preto-SP, avaliando a remoção dos metais pesados. A idéia de realização do projeto partiu dos estudos da Linha de Pesquisa em Saúde Ambiental, pela Profa. Dra. Susana Inés Segura Muñoz, que liderava um projeto intitulado: “Distribuição espacial e variação temporal de metais pesados na área de influência do aterro sanitário e antigo incinerador de resíduos sólidos de Ribeirão Preto, SP”. Projeto no qual venho colaborando desde 2003, ano em que realizei o aprimoramento no Laboratório de Pediatria, passando por diferentes treinamentos: coleta de amostras, laboratório de toxicologia, laboratório de urgência e o setor de metais onde desenvolvi as atividades por maior tempo.

O projeto mencionado anteriormente foi dividido em diferentes frentes, segundo as diferentes matrizes ambientais: um deles é o presente estudo do esgoto e lodo da Estação de Tratamento de Ribeirão Preto; o trabalho na água superficial do Córrego Monte Alegre analisado por Meire Nikaido, aluna de iniciação científica da EERP-USP do Laboratório de Saúde Ambiental, intitulado: “Análise dos níveis de metais no Córrego Monte Alegre localizado na área de influência do Aterro Sanitário e Incinerador de Resíduos Sólidos de Ribeirão Preto"; o trabalho de Marina Célere Smidt, aluna de iniciação científica da EERPUSP do Laboratório de Saúde Ambiental, no chorume intitulado como: “Análise dos níveis de metais pesados no chorume coletado no módulo I e no módulo II do Aterro Sanitário de Ribeirão Preto” e o trabalho da Kamila Piai, aluna de iniciação científica da EERP-USP do Laboratório de Saúde Ambiental, na água subterrânea, intitulado como: “Análise dos níveis 
de metais pesados em água subterrânea coletada nos poços localizados a montante e a jusante do Aterro Sanitário de Ribeirão Preto”.

O presente trabalho foi estruturado em cinco partes: introdução, objetivos, material e métodos, resultados e discussão, conclusão e considerações finais.

Na introdução é apresentados no contexto da saúde pública os seguintes conceitos: saúde ambiental, saneamento, esgoto sanitário, situação do saneamento básico e tratamento de esgoto no Brasil, no estado de São Paulo e Ribeirão Preto, o foco do estudo.

No presente estudo é apresentada a infra-estrutura de uma estação de tratamento de esgoto, abordando aspectos relacionados aos constituintes químicos, os metais pesados e aos sistemas de disposição do lodo para fins agrícolas. No final da introdução é enfatizado a realidade do Município de Ribeirão Preto, tendo descrito a evolução histórica e a situação atual. Em seguida são apresentados os objetivos do trabalho.

Posteriormente foi apresentada a metodologia que compreende, a descrição do local de estudo, a amostragem, as dosagens de metais em amostras de esgoto bruto, tratado e lodo mediante as diferentes técnicas espectrofotométricas.

Na seguinte seção foram apresentados os resultados obtidos e a discussão dos métodos. Os resultados obtidos da análise dos metais presentes nas amostras de esgoto não tratado, tratado e do lodo, juntamente com a análise estatística, possibilitou analisar a eficiência da remoção dos metais pesados presentes na estação de tratamento de esgoto de Ribeirão Preto. A discussão dos resultados obtidos foi analisada baseando-se nas recomendações nacionais e internacionais dos valores permitidos de metais pesados no esgoto tratado para descarga nos rios e valores máximos permitidos de metais para o lodo utilizado na agricultura, tomando como referência a literatura mundial existente nessa área.

A conclusão foi feita em tópicos enfatizando os principais resultados da remoção, dos valores de acordo com as normas nacionais e internacionais e também de grande importância 
em apresentar as informações às autoridades responsáveis pelo tratamento de esgoto de Ribeirão Preto.

Destaca-se de grande importância o apoio recebido da Fundação de Apoio à Pesquisa do Estado de São Paulo (FAPESP), o Laboratório de Saúde Ambiental da Escola de Enfermagem de Ribeirão Preto, o Setor de Metais do Laboratório de Pediatria e Puericultura do Hospital das Clínicas da Faculdade de Medicina de Ribeirão Preto/USP, o laboratório de Nutrição da Faculdade de Medicina de Ribeirão Preto/USP, o Laboratório de Toxicologia e Saúde Meio Ambiental da Universidade Rovira e Virgili na Espanha e da Estação de tratamento de esgoto por lodos ativados de Ribeirão Preto juntamente com o Departamento de Água e Esgoto de Ribeirão Preto (DAERP).

A partir deste estudo e de trabalhos relacionados foram elaborados artigos para sua divulgação em revistas científicas. Também foram apresentados resultados de alguns trabalhos oriundos dessa linha de investigação e de outras correlacionadas em congressos nacionais e internacionais, tais como:

\section{Artigos publicados em periódicos científicos:}

Segura-Muñoz, S.I.; Oliveira A.S.; Nikaido M.; Trevilato, T.M.B.; Bocio, A.; Takayanagui, A.M.M.; Domingo, J.L. Metal levels in sugar cane (Saccharum spp.) samples froma na area under the influence of a municipal landfill and a medical waste treatmetn system in Brazil. Environment International, v.32, n.1, p.52-57, 2005.

Trevilato, T.M.B., Segura-Muñoz, S.I.; Oliveira, A.S.; Pinto T.L.F.; Hering, S.E.; Cupo P. Uso de sistemas hidráulicos de cobre em água residencial coletada em Ribeirão Preto, São Paulo. O Mundo da Saúde, v. 29, n. 2, p. 238-242, 2005.

Nikaido, M.; Oliveira, A.S.; Trevilato, T.M.B.; Segura-Muñoz, S.I. Análise da qualidade da água do córrego Monte Alegre e afluentes, Ribeirão Preto, SP: enfoque para coliformes fecais e metais pesados. O Mundo da Saúde, v.28, n.4, p.414-420, 2004. 
Oliveira, A.S.; Grigoletto, J.C.; Segura-Muñoz, S.I.; Takayanagui, A.M.M. Use of Mercury in Odontology: a theoretical-Philosophical reflection. $5^{\mathrm{TH}}$ INTERNATIONAL CONGRESS OF PHARMACEUTICAL SCIENCES E II WORKSHOP DE EDUCAÇÃO EM CIÊNCIAS FARMACÊUTICAS. RIBEIRÃO PRETO-SP CIFARP-2005. Realizado do dia 25 a 28 de setembro de 2005. Revista Brasileira de Ciências Farmacêuticas, v.41, supl. 1, p. 404, 2005.

\section{Artigos encaminhados para publicação:}

Grigoletto; J.C.; Oliveira, A.S.; Takayanagui, A.M.M; Segura-Muñoz, S.I.; Alberguini, L.B.A. Exposição Ocupacional por uso de Mercúrio em Odontologia: uma revisão bibliográfica. Revista Ciência \& Saúde Coletiva. Artigo encaminhado para publicação em julho de 2005.

Oliveira, A.S.; Bocio, A.; Trevilato, T.M.B.; Takayanagui, A.M.M.; Domingo, J.L.; Segura-Muñoz, S.I. Heavy metals removal in treated/untreated wastewater and sludge from Ribeirão Preto Sewage Treatment Plant, Brazil. Sci. Env. Intern. Artigo encaminhado para publicação em outubro de 2005.

Oliveira, A.S.; Nikaido, M.; Celere, M.S.; Segura-Muñoz, S.I. Importância do biossólido gerado no sistema de tratamento de esgoto por lodos ativados, enfoque para a cidade de Ribeirão Preto, São Paulo, Brasil. O Mundo da Saúde. Artigo encaminhado para publicação em junho de 2005.

Celere, M.S.; Oliveira, A.S.; Trevilato, T.M.B.; Segura-Muñoz, S.I. Metais presentes no chorume coletado no Aterro Sanitário de Ribeirão Preto e sua relevância para Saúde Pública. Cadernos de Saúde Pública. Artigo encaminhado para publicação em novembro de 2005.

Nikaido, M.; Oliveira, A.S.; Trevilato, T.M.B.; Segura-Muñoz, S.I. Variação estacional dos níveis de metais na água do córrego monte Alegre e afluentes, Ribeirão Preto, SP. Revista de Saúde Pública. Artigo encaminhado para publicação em novembro de 2005.

\section{Artigos resumidos publicados em congressos nacionais e internacionais:}

Oliveira, A.S.; Nikaido, M.; Dias, A.C.; Sartori, I.T.; Trevilato, T.M.B.; Segura- Muñoz, S.I. Estudo de metais pesados em lodo gerado na estação de tratamento de esgoto de Ribeirão Preto, SP. In: IX ENCONTRO NACIONAL SOBRE CONTAMINANTES INORGÂNICOS E IV SIMPÓSIO SOBRE ESSENCIALIDADE DE ELEMENTOS DE NUTRIÇÃO HUMANA, São Paulo. Anais do IX Encontro Nacional sobre Contaminantes Inorgânicos. IPEN, v.1, p.111-112, 2004.

Nikaido, M.; Oliveira, A.S.; T.M.B.; Segura-Muñoz, S.I.. Análise de metais pesados na água do Córrego Monte Alegre e afluentes, Ribeirão Preto, SP. In: IX ENCONTRO NACIONAL SOBRE CONTAMINANTES INORGÂNICOS E IV SIMPÓSIO SOBRE ESSENCIALIDADE DE ELEMENTOS DE NUTRIÇÃO HUMANA, São Paulo. Anais do IX Encontro Nacional sobre Contaminantes Inorgânicos. IPEN, v.1, p.113-114, 2004. 
Trevilato, T.M.B.; Segura-Muñoz, S.I.; Oliveira, A.S.; Pinto, T.L.F.; Cupo, P. Níveis de cobre em água coletada em residências que possuem sistemas hidráulicos de cobre em Ribeirão Preto, SP. In: IX ENCONTRO NACIONAL SOBRE CONTAMINANTES INORGÂNICOS E IV SIMPÓSIO SOBRE ESSENCIALIDADE DE ELEMENTOS DE NUTRIÇÃO HUMANA, São Paulo. Anais do IX Encontro Nacional sobre Contaminantes Inorgânicos. IPEN, v.1, p.107-108, 2004.

Segura-Muñoz, S.I.; Oliveira A.S.; Nikaido M.; Trevilato, T.M.B.; Bocio, A.; Takayanagui, A.M.M.; Domingo, J.L. Concentración de metales en caña de azúcar (Saccharum officinarum) cultivada em el área del influencia del relleno sanitário y del sistema cel tratamiento de residuos de servicios de salud de Ribeirão Preto, Brasil. In: III SIMPÓSIO UNIVERSITÁRIO IBEROAMERICANO SOBRE MEDIO AMBIENTE, 2004, La Havana. Memorias del III Simposio Universitário Iberoamericano sobre Medioambiente. CUJAE, 2004. v.1, p.20-40.

Oliveira, A.S.; Nikaido, M.; Ferreira, C.R.; Segura-Muñoz, S.I. Implantação do sistema de Tratamento de Esgoto por lodos ativados no município de Ribeirão Preto, SP: Importância da avaliação de metais pesados no Lodo. CONGRESSO BRASILEIRO DE CIÊNCIA E TECNOLOGIA EM RESÍDUOS E DESENVOLVIMENTO SUSTENTÁVEL \& CICLO DE CONFERÊNCIA SOBRE POLÍTICA E GESTÃO AMBIENTAL. Realizado do dia 18 a 20 de outubro de 2004. Livro de resumos ICTR-NISAM, 2004. v.1, n.361.

Nikaido, M.; Oliveira, A.S.; Trevilato, T.M.B.; Segura-Muñoz, S.I. Análise da qualidade da água do Córrego Monte Alegre e afluentes, Ribeirão Preto, SP: reflexões sobre os efeitos na saúde derivados da utilização dessas águas. CONGRESSO BRASILEIRO DE CIÊNCIA E TECNOLOGIA EM RESÍDUOS E DESENVOLVIMENTO SUSTENTÁVEL \& CICLO DE CONFERÊNCIA SOBRE POLÍTICA E GESTÃO AMBIENTAL. Realizado do dia 18 a 20 de outubro de 2004. Livro de resumos ICTR-NISAM, 2004. v.1, n.361.

Nikaido, M.; Oliveira, A.S.; Trevilato, T.M.B.; Segura-Muñoz, S.I. Análise da qualidade da água do Córrego Monte Alegre e afluentes, Ribeirão Preto, SP: enfoque para metais e coliformes fecais. $12^{\circ}$ SIMPÓSIO INTERNACIONAL DE INICIAÇÃO CIENTÍFICA SIICUSP 2004. Disponível online: www.siicusp.usp.br

Oliveira, A.S.; Grigoletto, J.C.; Segura-Muñoz, S.I.; Takayanagui, A.M.M.; Alberguini, L.B.A. Mercúrio e Saúde Ocupacional na Odontologia. II SEMINÁRIO DE SAÚDE AMBIENTAL: EDUCAÇÃO AMBIENTAL E SAÚDE NA EERP-USP. Realizado no dia 17 de junho de 2005.

Oliveira, A.S.; Célere, M.S.; Bócio, A.; Takayanagui, A.M.M.; Domingo, J.L.; SeguraMuñoz, S.I. Análise de metais do biossólido gerado na estação de tratamento de esgoto por lodos ativados do município de Ribeirão Preto-SP. IX CONGRESSO PAULISTA DE SAÚDE PÚBLICA 2005. Realizado do dia 22 a 24 de outubro de 2005 em Santos-SP. Livro de resumos, v.14, p.260, 2005.

Célere, M.S.; Oliveira, A.S.; Trevilato, T.M.B; Segura-Muñoz, S.I. Análise dos níveis de metais presentes no chorume coletado no Módulo I e no Módulo II do Aterro Sanitário de Ribeirão Preto, SP. IX CONGRESSO PAULISTA DE SAÚDE PÚBLICA 2005. Realizado do dia 22 a 24 de outubro de 2005 em Santos-SP. Livro de resumos, v.14, p.269-270, 2005. 
Oliveira, A.S.; Grigoletto, J.C.; Segura-Muñoz, S.I.; Takayanagui, A.M.M.; Alberguini, L.B.A. Mercúrio e Saúde Ocupacional na Odontologia. IX CONGRESSO PAULISTA DE SAÚDE PÚBLICA 2005. Realizado do dia 22 a 24 de outubro de 2005 em Santos-SP. Livro de resumos, v.14, p.230-231, 2005.

Célere, M.S.; Oliveira, A.S.; Trevilato, T.M.B.; Segura-Muñoz, S.I. Metais presentes no chorume coletado no Aterro Sanitário de Ribeirão Preto e sua relevância para a saúde pública. In: 13 SIMPÓSIO INTERNACIONAL DE INICIAÇÃO CIENTÍFICA DA USP- SIICUSP, 2005, Ribeirão Preto-SP. 


\section{INTRODUÇÃO}

Nas últimas décadas, tem sido cada vez mais reconhecido, em nível mundial, que a promoção e proteção da saúde e bem-estar são determinadas, dentre outros fatores, pela qualidade do ambiente, equacionado num contexto mais amplo como resultado da ação combinada da sociedade no ambiente físico e social. Os efeitos favoráveis e desfavoráveis na saúde são condicionados pela qualidade dos vários componentes do meio físico, tais como: a água, o ar, o solo e alimentos. Por outro lado, os fatores antropológicos, sócioeconômicos, culturais e políticos influenciam o estado de saúde das populações, exercendo a sua ação, direta ou indiretamente, através da qualidade do ambiente físico em que se desenvolvem.

No mundo atual, o planeta terra e todos os seus seres estão com a qualidade de vida e seu equilíbrio ameaçados e com sinais de profunda crise de esgotamento, tanto na sua capacidade reparadora quanto regeneradora. Há sinais dessa crise em termos globais (como efeito estufa, elevação dos níveis dos oceanos, comprometimento da camada de ozônio, entre outros); no nível da saúde individual (aumento do número de casos de intoxicações químicas, de câncer, doenças neurológicas, imunológicas e estresse) e coletiva, decorrente dos desequilíbrios, desigualdades sociais e pela degradação dos espaços urbanos, dos solos cultiváveis e dos mananciais de água potável. No ambiente de trabalho, efeitos específicos causados por ruído, vibração, radiação, iluminação, descargas elétricas etc. vêm também originando uma série de agravos à saúde (SÃO PAULO. SECRETARIA DE ESTADO DA SAÚDE. CURSO BÁSICO DE VIGILÂNCIA AMBIENTAL EM SAÚDE. CBVA, 2001).

O ambiente é tudo que rodeia o homem ao longo de sua existência, seja ambiente biofísico (energia, alimentos, ar, solo, biota, água e hábitat), seja ambiente psicossocial (condições sociais, econômicas, políticas e culturais) que, mesmo em condições de artificialidade, interagem permanentemente entre si (SILVA, 2005). 


\subsection{Saúde pública e saneamento}

A Organização Mundial de Saúde (OMS) definiu, em 1946, que saúde significa um completo bem-estar físico, mental e social e não meramente a ausência de doença ou enfermidade. A saúde nem sempre é considerada de acordo com sua definição; ainda hoje, o que predomina é o modelo biomédico tradicional, fundamentado em ações curativas, baseadas num modelo que prioriza partes do corpo biológico, sem considerar a integralidade da assistência, trazida pela definição de saúde da OMS. Porém, já são visíveis os sinais de crise e mudança desse modelo sanitário, que tem se mostrado incapaz de enfrentar com eficácia o quadro epidemiológico da atualidade.

As transformações ocorridas no mundo contemporâneo, ao longo das últimas décadas, têm colocado a humanidade no limiar de uma etapa singular da sua história; no campo da política e da economia, tais transformações têm sido chamadas de "globalização" e causado impacto, de maneira significativa, no campo da saúde (CARVALHO, 1996). Tais transformações estimularam a adoção de novo paradigma, menos fragmentado e incorporado à visão holística, que orienta as mudanças de atitude e as preocupações a respeito do processo saúde-doença.

Em linhas gerais, aponta para um modelo sanitário mais amplo e complexo e incorpora os fatores ambientais, sociais, políticos, econômicos, comportamentais, biológicos e médicos, como determinantes da saúde (CARVALHO, 1996).

O conceito atual de saúde-doença amplia o modelo epidemiológico tradicional constituído pelo agente, hospedeiro e ambiente, sustentando que a saúde é determinada por um grupo de vários fatores, trazendo alternativa à tradicional explicativa microbiológica/ecológica, com nova visão de saúde, determinada por um conjunto de fatores agrupados em quatro categorias. 


\section{Estilo de vida}

Biologia Humana - envolve a herança genética e o processo de envelhecimento.
Ambiente - agrupa fatores externos ao corpo biológico, sobre os quais o indivíduo exerce pouco ou nenhum controle, nas suas dimensões física, social e psicológica. engloba as atividades de lazer, o padrão de vida e consumo e as situações ocupacionais (trabalho).

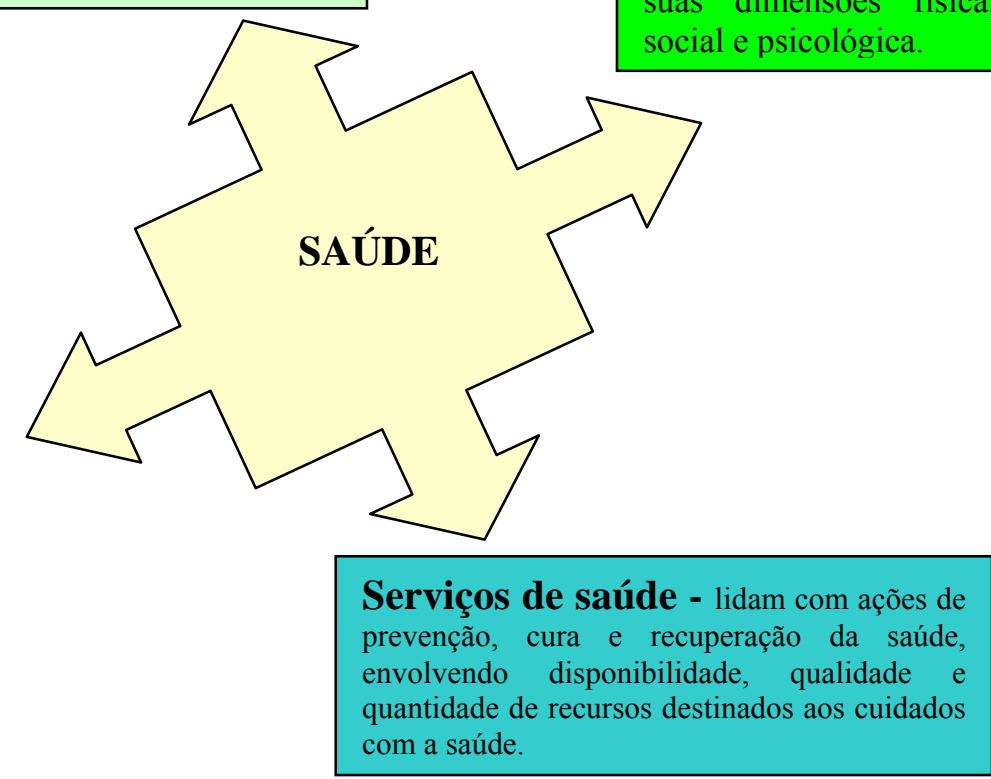

Figura 1 - Visão de saúde agrupadas em quatro categorias

Nem a saúde nem a doença são estáticas, trata-se de processos contínuos. Qualquer que seja a fonte ou o tipo de estímulo patológico e qualquer que seja a extensão da resposta do homem, o resultado é um processo. A saúde é o resultado de forças em constante reação, e a ocorrência de doenças em indivíduos, ou sua distribuição por grupos humanos, há que se considerar as múltiplas causas que influenciam as relações agente-hospedeiro no meio ambiente, antes e durante o processo da doença (CLARK; LEAVELL, 1977).

Com o crescimento populacional acelerado, onde não há rede de abastecimento de água, tratamento de esgotos ou disposição de resíduos sólidos, há um quadro caótico do ponto de vista sanitário e ambiental, e isso vai acarretar um meio propício para a propagação de doenças de veiculação hídrica e outras correlacionadas a esse crescimento sem infra-estrutura, tornando-se um grande problema de saúde pública.

Dentro do contexto social e político, a saúde pública tem como objetivos garantir 
melhoria do estado de saúde da comunidade e aumento da longevidade, para isso utiliza estratégias de promoção da saúde, prevenção da doença e outras formas de intervenção. $\mathrm{O}$ desenvolvimento do conhecimento científico, aliado à maior conscientização das pessoas sobre a influência da qualidade ambiental na saúde, nos últimos anos, tem destacado o ambiente como um dos elementos determinantes de maior importância no processo saúdedoença do ser humano (CÂMARA, 2003).

Para desenvolver ações de promoção e prevenção, visando o controle dos riscos ambientais e a melhoria das condições do meio ambiente e da saúde das populações, é necessário construir indicadores que permitam visão abrangente e integrada da relação saúde e ambiente. Os indicadores visam a avaliação das fontes de emissão de poluentes como a poluição do ar e da água, a contaminação de solos e alimentos. As pessoas entram em contato com o meio ambiente e com os efeitos dos riscos ambientais, revelando também a necessidade de serem integradas as análises dos efeitos dos riscos ambientais para a saúde das populações, com o desenvolvimento e implementação de processos decisórios, políticas públicas e práticas de gerenciamento de riscos (SÃO PAULO. SECRETARIA DE ESTADO DA SAÚDE. CBVA, 2001).

Ainda, segundo essa mesma referência, a saúde ambiental é a parte da saúde pública que engloba os problemas (diagnóstico, análise e atenuação ou resolução), resultantes dos efeitos que o ambiente exerce sobre o bem-estar físico e mental do homem, como parte integrante de uma comunidade. Em relação à saúde ambiental se caracteriza como um sistema complexo, quando se deseja conhecer a globalidade de uma dada situação, o mais próximo do real, e sobre ela intervir. A saúde ambiental integra dimensões histórica, espacial e coletiva das situações, partindo de um compromisso ético com a qualidade de vida das populações e dos ecossistemas.

O saneamento do ambiente é o conjunto operacional da Saúde Ambiental, que 
engloba todas as ações isoladas ou em conjunto, destinadas a assegurar a saúde no contexto ambiental (SILVA, 2005).

O saneamento é um dos meios mais importantes de prevenção de doenças. Segundo a Organização Mundial da Saúde: saneamento é "o controle de todos os fatores do meio físico do homem que exercem ou podem exercer efeito deletério sobre o seu bem-estar físico, mental ou social” (MOTTA, 1993).

Outra definição é o saneamento como o conjunto de medidas adotadas, que visa modificar as condições do meio com a finalidade de prevenir doenças e promover a saúde, é essencial na garantia da saúde pública, abrangendo todos os serviços básicos como: abastecimento de água, destino de águas servidas e sistemas de esgoto, destino de resíduos, controle de animais e vetores de doenças, segurança alimentar, saneamento de moradias, locais de trabalho, escolas e áreas de recreação, tanto no cotidiano quanto em situações de emergência. Todas essas preocupações têm um objetivo comum, principalmente evitar a transmissão de doenças pela ingestão de água ou alimentos contaminados (VIEL, 1994).

No caso do saneamento, há relação entre mortalidade infantil e a população servida por abastecimento de água. O abastecimento de água, juntamente com a destinação correta de dejetos, é capaz de influir contra doenças como diarréias, esquistossomose, amebíase, shiguelose, febre tifóide e paratifóide, disenterias etc. A água poluída gerada pela falta de higiene pessoal e ambiental, e também por ausência de educação em saúde, está levando a altos índices de mortalidade infantil causados por diarréia (ROCHA et al., 2004).

É essencial a qualquer comunidade, e considerado como um serviço público, o abastecimento de água potável. O abastecimento de água está diretamente relacionado à necessidade de coleta, distribuição e tratamento das águas servidas, que é de extrema responsabilidade pública. Existem comunidades beneficiadas por sistemas públicos de abastecimento de água, mas que ainda não têm sistemas de esgotamento sanitário e, com isso, 
os esgotos acabam poluindo o solo, contaminando as águas superficiais e as do lençol freático (MIGUEL et al., 2004).

Os maiores problemas de poluição no Brasil são causados pela poluição do ar, das águas nas áreas urbanas, gestão precária de resíduos sólidos e poluição de usinas industriais, mineração e queimadas. Observa-se que a deficiência de saneamento básico está entre os maiores problemas de poluição, concentrando-se nas regiões Norte, Nordeste e Centro-Oeste e vêm causando anualmente milhares de casos de mortalidade infantil (BANCO MUNDIAL, 1998).

Segundo dados elaborados pelo Instituto de Pesquisa Econômica Aplicada - IPEA, para o período de 1985 a 1990, a taxa de mortalidade infantil nos domicílios com condições adequadas de saneamento foi de 21,9\%, enquanto nos domicílios, onde as condições de saneamento eram inadequadas, foi de 59,1\% (MIGUEL et al., 2004).

Atualmente, a cada 14 segundos morre uma criança vítima de doença hídrica (MORAES; JORDÃO, 2002). O número é alto, considerando-se que são vítimas indefesas e incapazes de busca por água tratada. Constata-se essa ocorrência entre as camadas mais carentes da população, em crianças que tenham histórico de imunodeficiência e subnutrição.

A diarréia, manifestação comum de doenças infecciosas, ainda se apresenta como uma das principais causas de mortalidade infantil nos países em desenvolvimento, envolvendo fatores de ordem ambiental, nutricional, sócioeconômico e cultural. As crianças são suas vítimas mais freqüentes, uma vez que a associação diarréia e subnutrição é geralmente fatal (ROCHA et al., 2004). E, com a disposição correta dos esgotos, é possível reduzir o índice de mortalidade infantil.

Esses fatos, em sua maioria, são atribuídos, principalmente, à falta de prioridade nos investimentos em saneamento básico, em especial à coleta e ao tratamento de esgoto (OGERA; PHILIPPI JR., 2004). 
A disposição segura dos esgotos sanitários podem reduzir infecções intestinais e infecções por helmintos, incluindo cólera, febre tifóide e paratifóide, disenterias e diarréias, verminoses e esquistossomose. Crianças de até 5 anos apresentam maior risco, por terem seus sistemas imunológicos não completamente desenvolvidos e, ainda, por estarem, eventualmente, enfraquecidas pela desnutrição. Não há dúvida de que, melhorando o saneamento, há uma melhoria da saúde pública, embora seja difícil prever se o impacto será direto ou indiretamente (MIGUEL et al., 2004).

Do ponto de vista econômico, o Instituto Brasileiro de Geografia e Estatística IBGE (2002), segundo a Associação Nacional dos Serviços Municipais - ASSEMAE, relata que, para cada $R \$ 1,00$ investido em saneamento, o setor público economizaria $\mathrm{R} \$ 4,00 \mathrm{em}$ medicina curativa; sem dúvida, um importante ganho econômico e social.

Jacobi (1990, p.122) constata que

A caracterização das políticas de saneamento, habitação e saúde explicita o nível de desigualdade gerado pelo não atendimento real dos direitos dos cidadãos, assim como demonstra que a extensão de certos serviços públicos, em especial de rede de água, têm fortes efeitos sobre a modificação de indicadores sociais básicos, dentre os quais a mortalidade infantil.

Ainda, segundo a Organização das Nações Unidas - ONU, cerca de 2 milhões de pessoas estão vivendo, nesse início do século XXI, em locais sem saneamento, onde não existe nem mesmo um vaso sanitário em condições higiênicas; mais de 1 milhão de pessoas, em todo o mundo, não têm acesso à água potável e, a cada ano, morrem mais de 3 milhões de pessoas vítimas de enfermidades relacionadas à contaminação ou falta de água. Para Kofi Annan, Secretário Geral da ONU, “nenhuma medida fará mais em reduzir as enfermidades e salvar vidas nos países em desenvolvimento que facilitar um acesso geral à água potável e aos serviços de saneamento” (ORGANIZAÇÃO DAS NAÇÕES UNIDAS. ONU, 2003, p. 1).

Assim, considera-se a relação entre a existência de sistema de esgotos sanitários e a promoção da saúde pública. Os benefícios gerados vão além do bem-estar físico, mental e 
social do homem, pois visam, também, a conservação dos recursos naturais e do meio ambiente em que vivemos.

\subsection{Saneamento e sistemas de esgotos sanitários}

A palavra esgoto costuma ser usada para definir tanto a tubulação condutora das águas servidas de uma comunidade como, também, o próprio líquido que flui por essas canalizações. Esse termo é usado para caracterizar os efluentes provenientes de diversas modalidades do uso de águas, tais como as de uso doméstico, comercial, hospitalar, industrial, de utilidade pública, de áreas agrícolas, de superfície, de infiltração, pluviais e outras fontes (CHAGAS, 2000).

Segundo Miguel et al. (2004), de acordo com a sua origem, os esgotos podem ser classificados em:

- sanitário, comum ou doméstico: proveniente principalmente de residências, edifícios comerciais, instituições ou quaisquer edificações que contenham instalações de banheiros, lavanderias, cozinhas, ou qualquer dispositivo de utilização de água para fins domésticos. Compõem-se essencialmente da água de banho, urina, fezes, papel, restos de comida, sabão e detergente provenientes de atividades domésticas (instalações de banheiros, cozinhas e lavanderias);

- industrial, proveniente de processos industriais. Assim sendo, cada indústria deverá ser considerada separadamente, uma vez que seus efluentes diferem até mesmo em processos industriais similares (JORDÃO; PESSOA, 1995);

- pluvial, decorrente da coleta da precipitação atmosférica e da lavagem das ruas.

A composição do esgoto sanitário é bastante variável, apresentando maior teor de impurezas durante o dia, ou seja, em horários mais utilizados para banho e trabalhos 
domésticos, e menor durante a noite. A matéria orgânica, especialmente fezes humanas, confere ao esgoto sanitário suas principais características, mutáveis com o decorrer do tempo, por sofrer diversas alterações até sua completa mineralização ou estabilização.

O esgoto é constituído por líquido contendo cerca de 99,9\% de água e 0,1\% de substâncias minerais e orgânicas em dissolução e em suspensão (BETTIOL; CAMARGO, 2000).

Águas residuárias são "qualquer despejo ou resíduo líquido com potencialidade de causar poluição". Esgoto é um "refugo líquido que deve ser conduzido a um destino final (Decreto $n^{\circ} 553$ de 16.01.76). Esgotos domésticos são os efluentes líquidos dos usos domésticos da água. Estritamente falando, podem ser decompostos em águas cloacais e águas resultantes de outros usos. Esgotos pluviais são as águas provenientes das precipitações (chuvas) e que chegam ao solo ou aos telhados já despidas de suas qualidades naturais, por sua passagem pela atmosfera, de onde trazem impurezas" (ASSOCIAÇÃO BRASILEIRA DE NORMAS TÉCNICAS - ABNT, 1973 apud INSTITUTO PARA A DEMOCRATIZAÇÃO DE INFORMAÇÕES SOBRE SANEAMENTO BÁSICO E MEIO AMBIENTE, 2005).

\subsubsection{Histórico dos sistemas de esgotamento sanitário no mundo, no Brasil e no Estado de São Paulo}

Desde as comunidades tribais, até o declínio do feudalismo, os tipos e estados básicos de doença acompanham o homem desde sua permanência na Terra, e foram as necessidades diferenciadas de homens doentes que criaram a medicina e a arte de tratá-los e confortá-los. A incidência e a prevalência de doenças típicas variavam de época e de lugar para lugar. O mundo criado, em termos de relacionamento homem-natureza, e no qual se vive, pode ser analisado por meio de doenças e acidentes, como exemplo, peste bubônica, 
especialmente a partir do século XIV (HUBERMAN, 1974), que relata os tipos de moradia, hábitos de higiene e modo de vida das populações da época; o raquitismo e escorbuto, causados por deficiências alimentares devido aos aspectos da classe social, da dieta e das condições de vida na época das grandes descobertas marítimas dos séculos XV e XVI; doenças respiratórias pelo pó de carvão no início da Revolução Industrial e outras (LAKATOS; BRUTSCHER, 2000).

Com o início da Revolução Industrial, aumentaram os relatos de doenças associadas ao ambiente que eram responsáveis por grande número de mortes (MENDES, 1995), como o estudo clássico de John Snow, em Londres que associou a mortalidade por cólera a um fator relacionado com o ambiente, a fonte abastecedora de água (CÂMARA, 2003). Fator muito preocupante, associado à fonte abastecedora de água, era a coleta das águas servidas.

A coleta das águas servidas já era preocupação das civilizações antigas. Em 3.750 a.C., eram construídas galerias de esgoto em Nipur (Índia) e na Babilônia. Em 3.100 a.C. eram empregadas manilhas de cerâmica para a canalização dos esgotos (AZEVEDO NETTO, 1984). Na Roma imperial eram feitas ligações diretas das casas até os canais. Por se tratar de iniciativa particular de cada morador, nem todas as casas apresentavam essas benfeitorias (METCALF; EDDY, 1977).

$\mathrm{Na}$ Idade Média, não se tem notícia de grandes realizações, no tocante à coleta de esgotos. Essa despreocupação com os efluentes domiciliares, aliada ao desconhecimento da microbiologia até meados do século XIX, certamente foram as causas das grandes epidemias ocorridas na Europa no período entre os séculos XVI e XIX, coincidindo com o crescimento das populações e o início da aglomeração urbana (SAWYER; MCCARTY, 1978).

Em Londres, somente em 1815 os esgotos começaram a ser lançados em redes coletoras, em Hamburgo iniciou-se em 1842, e em Paris, em 1890. Em 1860, surgiu o 
dispositivo de Mouras para tratar lodos de esgotos por processo anaeróbio e, em 1865, fizeram-se os primeiros experimentos sobre microbiologia de degradação de lodos. Os fundamentos biológicos, que acabariam dando origem ao processo de tratamento de esgotos, através de lodos ativados, começaram a ser investigados, na Inglaterra, em 1882, tendo culminado com o desenvolvimento do processo de tratamento por lodos ativados em 1914, por Arden e Lockett (METCALF; EDDY, 1977).

Segundo o autor citado acima, o grande desenvolvimento das cidades, ocorrido a partir do século XIX e início do século XX, influenciou outros países que seguiram o exemplo inglês e começaram a se preocupar com o tratamento de seus esgotos e, como resultado, em 1887, foi construída a Estação Experimental Lawrence, em Massachussetts, nos Estados Unidos da América (EUA).

Pode-se afirmar que, a partir daí, os países desenvolvidos, em especial a Inglaterra, a maioria dos outros países europeus, os EUA, o Canadá, a extinta União Soviética e o Japão começaram a tratar os esgotos de suas cidades.

$\mathrm{Na}$ década de 70, devido às diversas práticas de destino final de lodos, ao pouco controle ambiental e, ainda, à possível presença de produtos indesejáveis no solo ou água como até então era realizado, começou-se a regulamentar o lançamento do lodo no ambiente, definidas a partir de convenções ou acordos internacionais. Nas cidades brasileiras, a partir da década de 70, embora, ainda, em poucas cidades, começou a ocorrer um avanço na área de saneamento em água, esgoto, lixo e alimentos. No entanto, até o momento, a maioria das cidades brasileiras nem coleta e nem faz tratamento de seus esgotos, e terão, fatalmente, que realizá-los, sob pena de ficarem sem mananciais de água apropriada para o abastecimento público (METCALF; EDDY, 1977).

De acordo com dados nacionais mais recentes, dos 46,6 milhões de domicílios brasileiros, 18,9\% não são atendidos por rede geral de abastecimento de água, 33,3\% não 
possuem rede geral de esgotamento sanitário e 16,8\% não têm coleta de lixo (IBGE, 2002).

A pesquisa Nacional de Saneamento Básico (IBGE, 2002) revela que 97,9\% dos municípios brasileiros têm serviços de abastecimento de água; 78,6\% têm serviço de drenagem urbana e 99,4\% têm coleta de lixo. Esgotamento sanitário é o serviço que apresenta a menor taxa, com 52,2\% dos municípios com esgotamento sanitário, sendo 32,2\% com serviço de coleta e apenas $20,2 \%$ dos municípios brasileiros possuindo coleta e tratamento de esgoto. Em volume, no país, diariamente 14,5 milhões de $\mathrm{m}^{3}$ de esgoto são coletados, sendo que 5,1 milhões de $\mathrm{m}^{3}$ são tratados. A Região Sudeste tem a maior proporção de municípios com esgoto coletado e tratado (33,1\%), seguida das Regiões Sul $(21,7 \%)$, Nordeste $(13,3 \%)$, Centro-Oeste (12,3\%) e Norte (3,6\%), conforme o IBGE - Censo 2000.

O Sistema Nacional de Informações em Saneamento (BRASIL. MINISTÉRIO DAS CIDADES. SECRETARIA NACIONAL DE INFORMAÇÕES EM SANEAMENTO. SNIS, 2003), em levantamento realizado em 2003, aponta que a média do abastecimento de água nos domicílios urbanos brasileiros chega a 95,3\%. Em contrapartida, a coleta de esgoto sanitário é de cerca de 50,6\%. Entretanto, o fato alarmante é que o índice médio nacional de tratamento de esgoto é de apenas $28,2 \%$. Há que se destacar o baixo índice de tratamento de esgoto existente na maioria dos municípios brasileiros, bem como o baixo índice de atendimento à coleta de esgoto para a totalidade da população dos municípios. Os dados mostram a necessidade de serem implantadas estações de tratamento de esgoto, além de serem estabelecidas regras claras para o cumprimento de legislação pertinente ao saneamento básico dos municípios.

No Brasil, as primeiras intervenções do governo federal, no setor saneamento, foram iniciadas com a edição do Código das Águas, em 1934, com o intuito de controlar os recursos hídricos no país (OGERA; PHILIPPI JR., 2004). O Código das Águas foi de fundamental importância para a gestão pública do setor saneamento urbano, pois estabeleceu 
os primeiros instrumentos de controle do uso dos recursos hídricos (JORGE, 1987).

Na década de 70, foi instituído o Plano Nacional de Saneamento (PLANASA). Nesse período, diversos Estados criaram Companhias Estaduais de Saneamento, pois somente receberiam recursos financeiros do governo federal para o setor de saneamento aqueles municípios que aderissem ao Plano (BRASIL. MINISTÉRIO DA SAÚDE. FUNDAÇÃO NACIONAL DE SAÚDE. FUNASA, 1996). Até o início dos anos 80, os investimentos do PLANASA foram aplicados em obras de saneamento. Os recursos eram provenientes principalmente do Fundo de Garantia por Tempo de Serviço (FGTS) (OGERA; PHILIPPI JR., 2004).

Segundo Relatório da Conferência Nacional de Saneamento (BRASIL. CONFERENCIA NACIONAL DE SANEAMENTO. CNS, 1999), apesar de contradições contidas no PLANASA, esse pode ser considerado um dos planos mais bem-sucedidos da administração pública brasileira, pois, em pouco mais de 20 anos, foi possível estender os serviços de abastecimento de água e esgotos sanitários para cerca de 70 milhões de pessoas, como pode ser observado na Tabela 1.

Tabela 1 -Evolução da cobertura de água e esgoto no Brasil, 1970- 1991

\begin{tabular}{|c|c|c|c|}
\hline Ano & 1970 & 1991 & $2000 *$ \\
\hline População Total & 93.139 .100 & 146.917 .800 & 169.799 .177 \\
\hline População Urbana & 52.085 .000 & 110.876 .100 & 137.953 .959 \\
\hline Índice de Cobertura de Água & $45,7 \%$ & $81,2 \%$ & $89,1 \%$ \\
\hline Índice de Cobertura de & $44,2 \%$ & $64,3 \%$ & $70,0 \%$ \\
\hline \multicolumn{4}{|l|}{ Esgoto } \\
\hline População Rural & 41.054 .100 & 36.041 .700 & 31.845 .211 \\
\hline Índice de Cobertura de Água & $3,2 \%$ & $6,8 \%$ & $17,8 \%$ \\
\hline Índice de Cobertura de & $2,0 \%$ & $9,0 \%$ & $11,8 \%$ \\
\hline Esgoto & & & \\
\hline
\end{tabular}


Nesse período de 1970, de 1991 a 2000 ocorreu intensa urbanização brasileira. Por outro lado, houve aumento significativo em termos de cobertura de água e, de forma mais tímida, da cobertura de esgoto, pois, quanto à evolução do nível de cobertura e abastecimento de água na área urbana, passou de 45,7\% (1970) para 81,2\% (1991) e 89,1\% (2000). Já, na área rural, passou de 3,2\% (1970) para 6,8\% (1991) e 17,8 (2000). Em relação ao esgotamento sanitário, a evolução aconteceu de forma muito mais lenta, pois, em 1970, o nível de atendimento da área urbana era de 44,2\% em 1991 e passou para 64,3\%, e em 2000 foi para 70,0\%. Quanto à área rural, o atendimento era de 2,0\%, em 1970, 9,0\%, em 1991, e passou para $11,8 \%$ em 2000. No entanto, observa-se disparidades gritantes quando se compara o índice geral brasileiro de cobertura dos serviços de água e esgoto com os índices regionais: como exemplo tem-se que, daqueles $64,3 \%$ do nível de atendimento de esgoto que o Brasil apresentava em 1991, o destaque era para as Regiões Sudeste $(80,9 \%)$ e Sul $(64,7 \%)$, sendo que, por sua vez, a Região Norte apresentava $36,4 \%$, a Nordeste $35,8 \%$ e a CentroOeste 41,8\% (BRASIL. CNS, 1999; BRASIL. MINISTÉRIO DO PLANEJAMENTO E ORÇAMENTO - MPO, 1995; BRASIL. MINISTÉRIO DA SAÚDE. DATASUS, 2000). Em 2000, houve pouco avanço do índice de cobertura de água e esgoto no Brasil, mas o destaque ainda se repete para a Região Sudeste que apresenta maior índice de cobertura de água e esgoto no Brasil.

A cobertura de redes de abastecimento de água e esgoto no Brasil é apresentada na Tabela 2.

Tabela 2 - Coberturas de redes de abastecimento de água e esgoto no Brasil, na situação urbana, no ano 2000

\begin{tabular}{ccc}
\hline \hline UF & \% serviço rede geral água & $\begin{array}{c}\text { \% serviço rede geral } \\
\text { esgoto }\end{array}$ \\
\hline \hline Rondônia & 43,85 & 27,87 \\
Acre & 49,70 & 40,29 \\
Amazonas & 75,16 & 55,11 \\
Roraima & 95,54 & 74,64
\end{tabular}




\begin{tabular}{ccc} 
Pará & 56,49 & continuação \\
Amapá & 55,96 & 49,13 \\
Tocantins & 84,44 & 25,53 \\
Maranhão & 75,04 & 24,38 \\
Piauí & 87,30 & 35,21 \\
Ceará & 79,46 & 57,60 \\
Rio Grande do Norte & 92,45 & 43,87 \\
Paraíba & 90,07 & 49,85 \\
Pernambuco & 85,57 & 50,93 \\
Alagoas & 80,34 & 52,84 \\
Sergipe & 91,82 & 33,65 \\
Bahia & 89,45 & 56,29 \\
Minas Gerais & 96,55 & 57,37 \\
Espírito Santo & 96,33 & 81,91 \\
Rio de Janeiro & 84,81 & 77,47 \\
São Paulo & 97,22 & 85,10 \\
Paraná & 96,71 & 90,48 \\
Santa Catarina & 88,89 & 60,19 \\
Rio Grande do Sul & 92,43 & 81,65 \\
Mato Grosso do Sul & 89,69 & 76,95 \\
Mato Grosso & 77,03 & 20,26 \\
Goiás & 76,56 & 34,80 \\
Distrito Federal & 91,44 & 38,87 \\
\hline
\end{tabular}

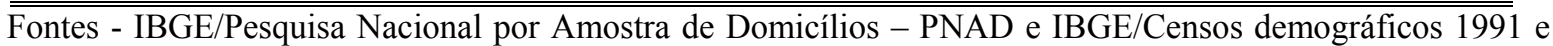
2000. Brasil. Ministério da Saúde. DATASUS, 2000.

Durante o processo de implantação do PLANASA, as prefeituras dos municípios que não aderiram ao plano criaram a Associação Nacional dos Serviços Municipais de Água e Esgoto (ASSEMAE) e, em meados da década de 80, por reivindicação dessa Associação, os órgãos municipais autônomos passaram a participar do PLANASA. A ausência de política de saneamento, levou à deterioração do PLANASA, resultando em ações públicas desarticuladas, incapazes de resolver os problemas relacionados ao abastecimento de água e ao esgotamento sanitário no Brasil (JORGE, 1987; BRASIL. MPO, 1995; BRASIL. MINISTÉRIO DA SAÚDE. FUNASA, 1996).

Depois da extinção do PLANASA, ocorreram reformas administrativas e os recursos financeiros foram repassados para as prefeituras e companhias estaduais, através de programas instituídos pelo governo federal. A fragilidade das políticas públicas e a 
precariedade dos serviços de saneamento no país, somadas ao significativo crescimento populacional, principalmente nas grandes cidades, levaram o governo brasileiro a constituir, em 1992, o Projeto de Modernização do Setor de Saneamento (PMSS) (OGERA; PHILIPPI JR., 2004).

O PMSS foi dividido em 2 fases, o PMSS-I e o PMSS-II. A primeira fase iniciouse em 1993 e foi finalizada no ano 2000. A segunda está em andamento, tendo iniciado no ano 2002. Ainda em relação ao PMSS-I, foi executado o componente institucional, previsto na primeira linha de ação do Projeto, com a elaboração de proposta de legislação federal sobre a prestação de serviços de saneamento e apoio aos Estados do Espírito Santo, Mato Grosso, Rio de Janeiro e São Paulo, entre outros, sobre proposição de instrumentos de regulação e controle. Já, em relação à segunda linha de ação do Projeto - componente investimentos - foi executado pelas companhias: Empresa Baiana de Saneamento (EMBASA), Empresa de Saneamento do Mato Grosso do Sul (SANESUL) e a Companhia Catarinense de Águas e Saneamento (CASAN). O PMSS-I contou com recursos do Banco Mundial da ordem de US\$ 250 milhões e a mesma quantidade em contrapartida nacional (BRASIL. SNIS, 2002).

Quanto ao PMSS-II, os recursos são da ordem de US\$ 150 milhões do Banco Mundial, US\$ 93,5 milhões do Japan Bank for International Cooperation -JBIC e US\$ 56,5 milhões em contrapartida dos prestadores de serviços. Essa fase do PMSS visa dar continuidade ao reordenamento institucional do saneamento, bem como ampliar a cobertura dos serviços de água e esgotamento sanitário em Estados das Regiões Norte, Nordeste e Centro-Oeste, dentre outros (BRASIL. SNIS, 2002).

Por outro lado, projetos de lei foram elaborados na tentativa de estabelecer políticas públicas nacionais para o saneamento tais como, o Projeto de Lei nº199, de 1991, PLC - Projeto Lei do Congresso 199, e o Projeto de Lei do Senado n ${ }^{\circ} 266$ PLS 266. O primeiro, dispunha sobre a Política Nacional de Saneamento, estabelecendo que cabia aos 
municípios a organização e prestação, diretamente ou mediante regime de concessão ou permissão, dos serviços públicos de saneamento e que os serviços de saneamento deveriam integrar-se com as demais funções essenciais de competência municipal, de modo a assegurar prioridade para a segurança sanitária e o bem-estar ambiental de seus habitantes. O PLS 266, de 1996, estabelecia diretrizes para o exercício do poder concedente e para o interrelacionamento entre União, Estados e Municípios. Trazia, também, colocações relativas a uma ação privatizante do governo federal, que definia como estaduais os poderes concedentes dos serviços de água e de esgotos das regiões metropolitanas, aglomerações urbanas e microrregiões. O objetivo principal dessa iniciativa, conclui-se, seria facilitar o processo de privatização das empresas estaduais de saneamento (BRASIL. CNS, 1999).

O PLC 199, de 1991, que tinha sido aprovado pelo Congresso em 1994, foi vetado na íntegra pelo executivo federal (BRASIL, Leis, Decretos, 1995).

Em relação à tramitação de PLS 266, de 1996, encontra-se desde 10/04/2002 na Comissão de Serviços de Infra-estrutura, conforme diz o portal do Legislativo do Senado Federal (BRASIL. SENADO, Leis, Decretos. 2002).

Desde então, o Brasil não conta com políticas públicas nacionais para o saneamento básico, o que leva os Estados e municípios a definições próprias de suas políticas públicas, podendo provavelmente estar desarticuladas, tanto em âmbito de governo como entre setores de planejamento. A questão é sumamente importante, tanto que, em 2001, foi elaborado o Projeto de Lei 4147, que trata das diretrizes nacionais para a prestação dos serviços de saneamento básico e define a política de saneamento, que, em 2003, entrou no Congresso Nacional (OGERA; PHILIPPI JR., 2004).

No que tange à forma de gestão dos serviços de abastecimento de água e esgotamento sanitário no Brasil, esses vêm sendo administrados pelos Estados por meio de companhias, mediante concessões municipais, e pelos municípios, por meio de administração 
municipal direta, ou autarquias, ou empresa públicas ou, ainda, assistidos pela Fundação Nacional de Saúde (OGERA; PHILIPPI JR., 2004).

Segundo o SNIS, as companhias estaduais operam 3921 municípios com serviços de água, 880 com serviços de esgoto e cerca de 40 municípios têm os seus serviços operados por concessionárias privadas. Os 1600 municípios prestam diretamente os seus serviços de água. Com relação ao esgotamento sanitário, a situação é precária, pois cerca de 4700 municípios, cujos serviços de esgotos não são operados pelas companhias estaduais, alguns operados por autarquias municipais, outros são operados por departamentos da própria prefeitura e em outros não existe qualquer tipo de serviço (ASSOCIAÇÃO NACIONAL DOS SERVIÇOS MUNICIPAIS DE SANEAMENTO. ASSEMAE, 2005).

Apresenta-se, na Tabela 3, a distribuição, em termos percentuais, das condições de coleta e tratamento de esgoto nas regiões brasileiras. O que pode ser observado é que $47,8 \%$ dos municípios não têm coleta de esgoto, sendo seus principais receptores os rios e oceanos, dos restantes 52,2\%, que possuem coletam de esgoto, 32,0\% têm serviço de coleta, e apenas $20,2 \%$ coletam e tratam esgoto. Em volume, no país, diariamente, 14,5 milhões de $\mathrm{m}^{3}$ de esgoto são coletados, sendo que 5,1 milhões são tratados (IBGE, 2002).

Tabela 3 - Coleta e tratamento de esgoto nos municípios Brasileiros em 2002

\begin{tabular}{lccc}
\hline \hline \multicolumn{4}{c}{ Percentual de Municípios (\%) } \\
\hline \hline Região & $\begin{array}{c}\text { Com coleta e } \\
\text { tratamento de esgoto }\end{array}$ & $\begin{array}{c}\text { Com coleta e sem } \\
\text { tratamento de esgoto }\end{array}$ & Sem coleta de esgoto \\
\hline \hline Norte & 3,6 & 3,5 & 92,9 \\
Nordeste & 13,3 & 29,6 & 57,1 \\
Sudeste & 33,1 & 59,8 & 7,1 \\
Sul & 21,7 & 17,2 & 61,1 \\
Centro-Oeste & 12,3 & 5,6 & 82,1 \\
Brasil (total) & 20,2 & 32,0 & 47,8 \\
\hline \hline
\end{tabular}

Fonte - IBGE. PNSB - Pesquisa Nacional de Saneamento Básico, 2002. 
A Região Norte é a que apresenta maior proporção de municípios sem coleta (92,2\%), seguido do Centro-Oeste $(82,1 \%)$, do Sul $(61,1 \%)$, do Nordeste $(57,1 \%)$ e do Sudeste $(7,1 \%)$. Nesses casos, os principais receptores do esgoto in natura não coletados são os rios e mares, comprometendo, dessa forma, a qualidade da água utilizada para abastecimento, irrigação e recreação.

De acordo com dados publicados por Miguel et al. (2004), o serviço público de esgotamento sanitário das residências paulistanas foi iniciado em 25 de junho de 1887, com a criação da Companhia Cantareira. O Governo do Estado, através da Secretaria da Agricultura, adquiriu, em 26 de dezembro de 1892, a Companhia Cantareira de Esgotos, que pouco mais adiante mudou para Repartição de Águas e Esgotos (RAE). Ao longo do tempo, ocorreram marcos importantes em relação aos sistemas de esgotamento em São Paulo.

- A RAE iniciou suas atividades em 1911, tomando as primeiras medidas no sentido de construir novas redes exclusivamente para esgotos sanitários e eliminando aos poucos as ligações existentes de condutos de águas pluviais à rede velha. Os esgotos coletados eram lançados in natura nos córregos tributários dos rios Tamanduaté́, Pinheiros e Tietê. O RAE colocou em operação uma unidade de tratamento de esgotos localizada na Ponte Pequena, como uma instalação experimental. Com os dados da experiência ali obtidos, foi projetada e construída, já em escala industrial, a Estação Experimental do Ipiranga, hoje denominada João Pedro de Jesus Netto. Foi a primeira estação depuradora para esgotos sanitários domiciliares, construída na cidade, entrando em funcionamento em 1937.

- Em 1942, o chamado Plano Geral dividia a cidade em cinco zonas sanitárias situadas na Penha, Santana, Vila Leopoldina, Pinheiros e Santo Amaro.

- Outro plano surgiu em 1950, baseado no anterior de autoria de Plínio de 
Queiroz.

- Em 1956, entrou em operação a ETE de Vila Leopoldina com capacidade para $3,65 \mathrm{~m}^{3} / \mathrm{s}$.

- Na década de 60 e 70, em favor do controle dos esgotos domésticos e nãodomésticos, não só em nível metropolitano, mas estadual, datam, incluindo-se a criação da CETESB em 1968, a instituição da Lei Estadual nº 997 em 1976 e do respectivo regulamento, expresso pelo Decreto $n^{0}$ 8468/76. Essas legislações, acrescidas de outros dispositivos legais subseqüentes, dispuseram sobre a prevenção e o controle da poluição do meio ambiente, definindo o enquadramento dos corpos hídricos em classes preponderantes de uso e estabelecendo os níveis admissíveis para o lançamento de poluentes (GRISOTTO; PHILIPPI JR., 2004).

- Em 1961, o DAE (Departamento de Água e Esgoto) contratou o projeto e a construção da Estação de Tratamento de Pinheiros, que teve sua conclusão em 1971.

- Em 1964, foi contemplado o plano HIBRACE (Plano Diretor de Obras de Aproveitamento Múltiplo dos Recursos Hídricos da Bacia do Alto Tietê). Era escopo o desvio de grande parte dos esgotos dos rios Tietê e Pinheiros até um ponto nas margens do Reservatório Billings, onde seria implantada uma Estação de Tratamento do Vale do Guacuri. O restante seria tratado nas Estações a serem construídas em São Miguel e Suzano. Aquelas então existentes na Vila Leopoldina e Pinheiros seriam transformadas em estações elevatórias.

- Entre 1978 e 1985, foram construídas duas estações de tratamento de esgotos, uma no extremo leste da RMSP (Região Metropolitana de São Paulo) no 
município de Suzano, com capacidade de $1,5 \mathrm{~m}^{3} / \mathrm{s}$, e outra na região oeste, em Barueri, cujo primeiro módulo apontava a capacidade de processamento de 3,5 $\mathrm{m}^{3} / \mathrm{s}$, além da implantação de sistemas coletores e interceptores que atendiam cerca de 50\% da população de São Paulo (GRISOTTO; PHILIPPI JR., 2004).

- Em 1985, foi contratado o convênio ENGIESAN para desenvolvimento da revisão do Plano Diretor de Esgotos da RMSP, denominado COPLADES (Construção do Plano Diretor de Esgotos), encerrado em 1988, e que apresentou um estudo com oito alternativas. Optou-se, então, por dividir a RMSP em duas áreas - uma central e outra principal - compondo, assim, o atual Sistema Integrado e os Sistemas Isolados. Foi desse plano que surgiu a atual composição do Sistema de Esgotamento Sanitário da RMSP, estando em constante revisão e atualização.

Historicamente, a RMSP privilegiou a infra-estruturação das áreas urbanas em busca da coleta e afastamento dos esgotos, mas não se preocupou com o tratamento de esgotos.

Pouco se avançou, pois as próprias políticas municipais, até os anos 80, restringiam-se às questões de saneamento, abastecimento de água e canalização de córregos, ignorando-se questões mais abrangentes, como aquelas relacionadas à gestão ambiental em nível regional. Não havia, assim, nenhum tipo de integração, tanto entre as diversas políticas municipais, como dessas com as políticas estaduais ou federais, o que se caracterizou na ausência de um processo de planejamento sistêmico que compatibilizasse o desenvolvimento econômico à sustentabilidade ambiental, internalizando, por exemplo, a questão dos esgotos domésticos e dos efluentes industriais (GRISOTTO; PHILIPPI JR., 2004).

Atualmente, segundo informações do Censo (IBGE, 2002), pouco mais de $81 \%$ dos domicílios permanentes da RMSP conta com unidades sanitárias ou banheiros conectados 
às redes coletoras de esgoto, cujo índice é bastante semelhante ao do Estado de São Paulo, com $81,7 \%$ dos domicílios com banheiros também conectados. Se o atendimento com redes de esgotamento sanitário reduz os riscos de contaminação e possibilita maior salubridade humana e ambiental, deve-se assegurar que os efluentes destinados às redes sejam efetivamente processados pelas estações de tratamento.

O Estado de São Paulo tem 645 municípios, dos quais 279 têm serviços de água e esgoto, administrados no âmbito local do município, a maioria tem gestão pública e uma pequena parcela tem participação da iniciativa privada. No Estado de São Paulo, concentra-se o maior número de concessões privadas, variando desde municípios pequenos com cerca de 3.000 habitantes a municípios de grande porte com cerca de 460.000 habitantes (OGERA; PHILIPPI JR., 2004).

No entanto, a desigualdade dos serviços prestados se repete: quanto maior a população do município, maior a quantidade de domicílios com serviço de esgoto. Os municípios com mais de 300.000 habitantes têm quase três vezes mais domicílios ligados à rede geral de esgoto do que os domicílios em municípios com população até 20.000 habitantes (IBGE, 2002).

Nesse contexto, embora as condições sejam precárias e haja muito o que melhorar, o Estado de São Paulo é a unidade da federação que possui maior percentual com coleta e tratamento de esgotos.

\subsection{Tecnologias para tratamento de esgotos sanitários}

No campo de tecnologias para o tratamento de esgotos sanitários, a escolha entre as diversas alternativas disponíveis é ampla e depende de diversos fatores, entre eles: a área disponível para implantação da Estação de Tratamento de Esgoto (ETE); topografia dos 
possíveis locais de implantação e das bacias de drenagem e esgotamento sanitário; volumes diários a serem tratados e variações horárias e sazonais da vazão de esgotos; características do corpo receptor de esgotos tratados; disponibilidade e grau de instrução da equipe operacional responsável pelo sistema; disponibilidade e custos operacionais de consumo de energia elétrica; clima e variações de temperatura da região; disponibilidade de locais e/ou sistemas de reaproveitamento e/ou disposição adequados dos resíduos gerados pela ETE (SÃO PAULO. SECRETARIA DO MEIO AMBIENTE. CIÊNCIA E TECNOLOGIA À SERVIÇO DO MEIO AMBIENTE. CETESB, 1988).

De acordo com a área, com os recursos financeiros disponíveis e com o grau de eficiência que se deseja obter, um ou outro processo de tratamento pode ser mais adequado. A estimativa de eficiência esperada nos diversos níveis de tratamento: preliminar, primário, secundário e terciário são incorporados numa ETE.

O tratamento de esgotos pode ser dividido em níveis de acordo com o grau de remoção de poluentes que se deseja atingir. O tratamento primário destina-se à remoção de sólidos grosseiros em suspensão (materiais de maiores dimensões e sólidos decantáveis como areia e gordura). São utilizados apenas mecanismos físicos (gradeamento e sedimentação por gravidade) como método de tratamento. Essa etapa tem a finalidade de proteger as unidades de tratamento subseqüentes e dispositivos de transporte como, por exemplo, bombas e tubulações, além de proteção dos corpos receptores quanto aos aspectos estéticos.

O tratamento primário, além dos sólidos sedimentáveis, remove também boa parte da matéria orgânica, utilizando-se de mecanismos físicos como método de tratamento.

O tratamento secundário, geralmente constituído por reator biológico, remove grande parte da matéria orgânica, podendo remover parcela dos nutrientes como nitrogênio e fósforo. Os reatores biológicos empregados para essa etapa do tratamento reproduzem os fenômenos naturais da estabilização da matéria orgânica que ocorreriam no corpo receptor. 
O tratamento terciário, nem sempre presente, geralmente constituído de unidade de tratamento físico-químico, tem como finalidade a remoção complementar da matéria orgânica, dos nutrientes, de poluentes específicos e a desinfecção dos esgotos tratados. Isso pode ser visualizado na Tabela 4 (SÃO PAULO. SECRETARIA DO MEIO AMBIENTE. CETESB, 1988).

Tabela 4 - Estimativa da eficiência esperada nos diversos níveis de tratamento incorporados numa ETE

\begin{tabular}{|c|c|c|c|c|}
\hline $\begin{array}{l}\text { Tipo de } \\
\text { tratamento }\end{array}$ & $\begin{array}{l}\text { Matéria orgânica } \\
\text { (\% remoçãode } \\
\text { DBO) }\end{array}$ & $\begin{array}{c}\text { Sólidos em } \\
\text { suspensão } \\
\text { (\% remoção SS) }\end{array}$ & $\begin{array}{l}\text { Nutrientes } \\
\text { (\% remoção } \\
\text { nutrientes) }\end{array}$ & $\begin{array}{c}\text { Bactérias } \\
(\% \\
\text { remoção })\end{array}$ \\
\hline Preliminar & $5-10$ & $5-20$ & Não remove & $10-20$ \\
\hline Primário & $25-50$ & $40-70$ & Não remove & $25-75$ \\
\hline Secundário & $80-95$ & $65-95$ & Pode remover & $70-99$ \\
\hline Terciário & $40-99$ & $80-99$ & Até 99 & Até 99,999 \\
\hline
\end{tabular}

Fonte - SÃO PAULO. SECRETARIA DO MEIO AMBIENTE. CETESB, 1988.

A seguir, na Figura 2, estão representadas as etapas de funcionamento de uma estação de tratamento de esgoto. Inicialmente, é chegado o esgoto bruto através de interceptores onde são retirados os sólidos grosseiros, sedimentados com um guindaste e colocados em um contêiner para serem enviados a um aterro sanitário. $\mathrm{O}$ efluente é bombeado para o desarenador e desengordurador, onde são extraídas toda areia e gordura presentes no esgoto e todo resíduo retirado é colocado em um contêiner. Segue o tratamento em direção ao decantador primário, onde ocorre a separação de sólidos sedimentáveis e dissolvidos. Em seguida, o efluente vai para o tanque de aeração para fornecer oxigênio aos microorganismos para ser degradada toda a matéria orgânica contaminante. Saindo do tanque de aeração, o efluente vai para o decantador secundário, onde a parte líquida é separada do lodo restante, constituindo o lodo ativado, e o efluente será encaminhado ao rio. 
Nessa separação no decantador secundário, uma parcela desse lodo retorna ao tanque de aeração e a outra parcela é encaminhada para os adensadores de gravidade, juntamente com os sólidos sedimentados, separados no decantador primário, ou seja, o lodo é formado a partir dos materiais sólidos retidos. Os adensadores são para diminuir o volume do lodo, sendo que esse será levado para os digestores, onde será feita a homogeneização e estabilização do lodo, passando pelo filtro-prensa, reduzindo ainda mais o teor de água e, em seguida, o lodo é desidratado e, logo, bombeado para um contêiner no alto, facilitando a coleta do caminhão que encaminhará o lodo para o aterro sanitário ou para outros fins.

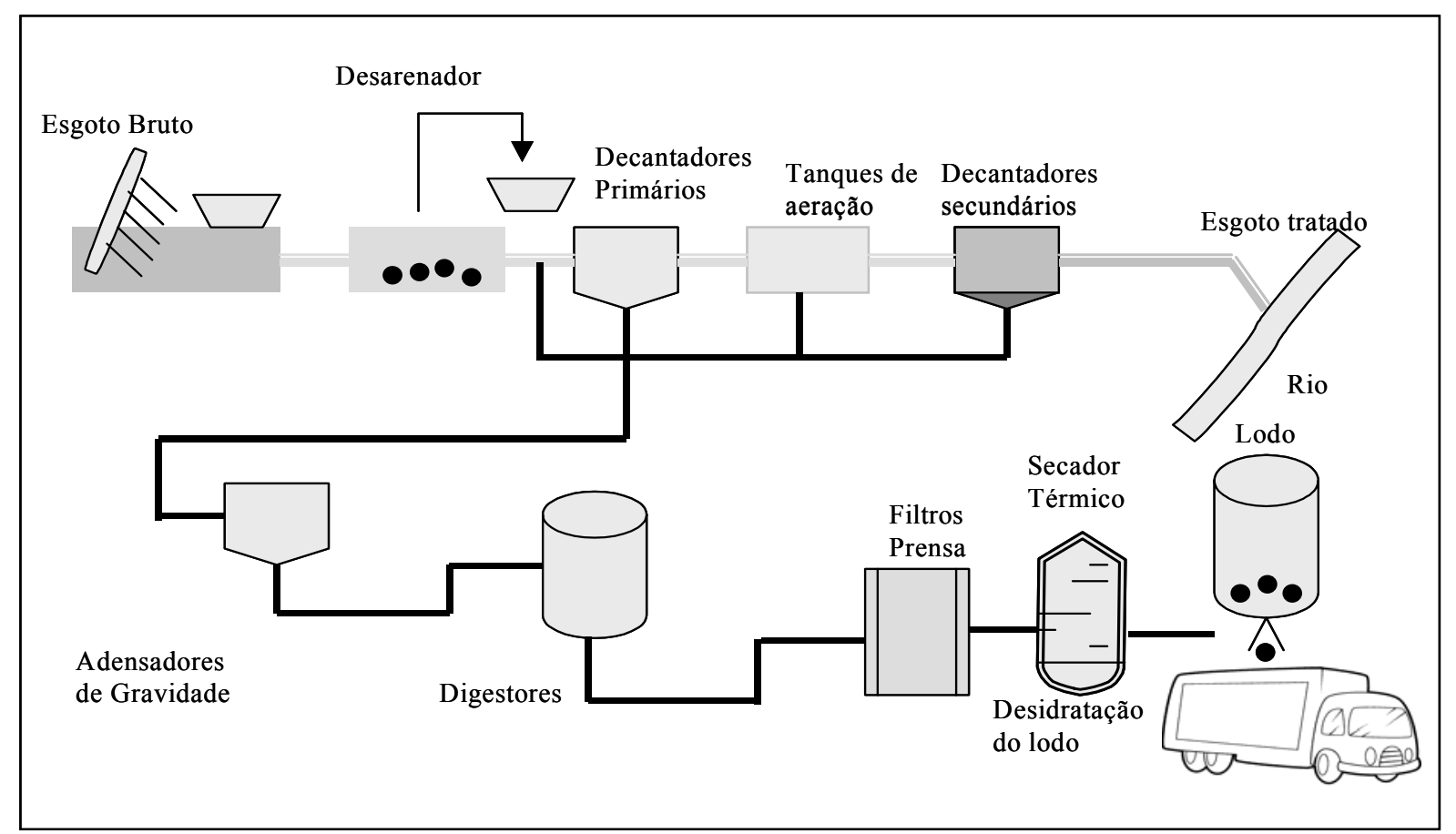

Figura 2 - Esquema das etapas do funcionamento de uma estação de tratamento de esgoto

Os processos de tratamento já são de conhecimento geral, com algumas pequenas diferenças entre os diversos processos. O principal problema encontrado em relação ao tipo de esgoto até o momento, que é de difícil solução, está na produção de lodos resultantes desse tratamento, bem como de seu destino final. Assim, as práticas para o aproveitamento, ou simples disposição do lodo, são ainda bastante antigas nos países mais desenvolvidos, sendo, 
portanto, ainda não satisfatórias, como a incineração e a disposição nos oceanos e aterros sanitários.

\subsection{Esgoto sanitário e metais pesados}

Enquanto o esgoto sanitário causa poluição orgânica e bacteriológica, o industrial geralmente produz a poluição química. O efluente industrial, além das substâncias presentes na água de origem, contém impurezas orgânicas e/ou inorgânicas, resultantes das atividades industriais, em quantidade e qualidade variáveis com o tipo de indústria.

Os corpos d'água podem se recuperar da poluição, ou depurar-se, pela ação da própria natureza. $\mathrm{O}$ efluente, geralmente, pode ser lançado sem tratamento em um curso d'água, desde que a descarga poluidora não ultrapasse cerca de quarenta avos da vazão: um rio com $120 \mathrm{~L} / \mathrm{s}$ de vazão pode receber, grosso modo, a descarga de $3 \mathrm{~L} / \mathrm{s}$ de esgoto bruto, sem maiores conseqüências (SÃO PAULO. SECRETARIA DO MEIO AMBIENTE. CETESB, 1988).

Freqüentemente, os mananciais recebem cargas de efluentes muito elevadas para sua vazão e não conseguem se recuperar pela autodepuração, havendo a necessidade da depuração artificial ou tratamento do esgoto. O tratamento do efluente pode, inclusive, transformá-lo em água para diversos usos, como a irrigação, por exemplo.

O tratamento de águas residuárias tem assumido papel importante no que se refere aos aspectos de saúde pública e controle da poluição ambiental. Considerando os elementos constituintes dos despejos urbanos e industriais, além da carga microbiológica, podem conter diversos poluentes químicos que afetam a saúde humana. Dentre os constituintes químicos destacam-se os metais pesados que, sendo indevidamente removidos, poderão causar poluição significativa no corpo receptor, representando risco para a saúde humana e ambiental. 
A presença de metais pesados, definidos como elementos químicos com densidade maior que $5 \mathrm{~g} / \mathrm{cm}^{3}$ no lodo de esgoto, tem sido objeto de muitos estudos devido ao impacto ambiental desses elementos na saúde humana, animal e na qualidade do alimento. Ao contrário dos patógenos e dos compostos orgânicos, que o lodo geralmente apresenta, os metais pesados podem acumular-se no solo por tempo indefinido. Em geral, os metais pesados encontrados no lodo de esgoto são: $\mathrm{Cd}, \mathrm{Cr}, \mathrm{Cu}, \mathrm{Ni}, \mathrm{Pb}, \mathrm{Fe}, \mathrm{Co}, \mathrm{Mn}, \mathrm{Mo}, \mathrm{Hg}, \mathrm{Sn}$ e Zn. Entre esses, deve-se ressaltar que alguns são essenciais às plantas $(\mathrm{Cu}, \mathrm{Fe}, \mathrm{Mn}, \mathrm{Mo}, \mathrm{Ni}$ e $\mathrm{Zn})$, às bactérias fixadoras de nitrogênio (Co) e aos animais ( $\mathrm{Co}, \mathrm{Cr}, \mathrm{Cu}, \mathrm{Fe}, \mathrm{Mn}$, Mo e $\mathrm{Zn})$.

O lodo de esgoto, estritamente urbano, possui, via de regra, quantidade baixa de metais pesados, mas, quando esgotos industriais e água de chuva entram no sistema de captação do esgoto urbano, esse pode ter sua concentração de metais aumentada significativamente (BERTON, 2000).

Metais pesados como chumbo $(\mathrm{Pb})$, mercúrio $(\mathrm{Hg})$, cádmio $(\mathrm{Cd})$, arsênio $(\mathrm{As})$, cromo $(\mathrm{Cr})$, zinco $(\mathrm{Zn})$, cobre $(\mathrm{Cu})$, manganês $(\mathrm{Mn})$ e níquel $(\mathrm{Ni})$, dentre outros, são considerados os metais de maior interesse em termos de saúde pública (PEIRANO, 2002). Alguns deles são nutrientes importantes no desenvolvimento da vida. Porém, em teores elevados, podem causar sérios riscos para o desenvolvimento das plantas e para a saúde dos animais. Assim, o grande problema é o risco de acumulação desses elementos nos solos, nas plantas, nos animais, com especial destaque ao organismo humano (SEGURA-MUÑOZ et al., 2004, 2006).

Os metais pesados, em concentrações superiores às legalmente recomendadas, têm sido responsabilizados por causar agravos à saúde, além de uma série de doenças carcinogênicas (DENILON; SILBERGELD, 1988; MAGOSSI; BONACELLA, 1991; SERRA; GROSSI; PIMENTEL, 1998).

Os efeitos tóxicos desses metais encontram-se amplamente descritos na literatura, 
sendo que a gravidade depende do grau de exposição aos mesmos. Dentre os efeitos adversos, apontam-se danos do sistema nervoso central, no sistema hepático, no sistema renal, no sistema hematopoiético e no sistema esquelético (DENILON; SILBERGELD, 1988; KREISS, 1990; STOEWSAND et al., 1990; COSTA, 1998; HARADA et al., 1999; IREGREN, 1999; KELLEY, 1999; LAI et al., 1999; PAL; SAMII; CALNE, 1999; STAESSEN et al., 1999; VIAENE et al., 1999).

Dentre os metais pesados, podem ser citados o $\mathrm{As}, \mathrm{Be}, \mathrm{Cd}, \mathrm{Cr}, \mathrm{Cu}, \mathrm{Fe}, \mathrm{Hg}, \mathrm{Mn}, \mathrm{Ni}$, $\mathrm{Pb}, \mathrm{Sn}, \mathrm{Tl}, \mathrm{V}$ e $\mathrm{Zn}$ como os mais estudados pelos seus efeitos na saúde; uma descrição mais detalhada desses metais é apresentada a seguir.

Arsênico (As) é um semimetal, muito quebradiço, cristalino, incolor e inodoro (SAKUMA; DE CAPITANI; TIGLEA, 2003).

O As é utilizado na produção de vidros, ligas não-ferrosas, produtos eletrônicos (CARAPELLA, 1992), madeiras (US. AGENCY FOR TOXIC SUBSTANCES AND DISEASE REGISTRY - ATSDR, 2000), na agricultura em praguicidas (ATSDR, 2000; BRASIL. MS., 2000) e em promotores de crescimento em rações para aves e suínos (WORLD HEALTH ORGANIZATION - WHO, 2001).

Além do As colocado diretamente junto ao ambiente como produto, no caso da agricultura ou na conservação de madeiras, a atividade humana também provoca emissões em que o As é produzido diretamente como poluente. Isso ocorre, principalmente, por usinas termoelétricas ou fundições onde ocorre queima de grandes quantidades de carvão e na refinação de metais, onde o As é subproduto lançado à atmosfera e ao solo. A queima de carvão e as fundições de cobre são responsáveis por cerca de $60 \%$ das emissões antropogênicas e, essas por sua vez, correspondem a $60 \%$ do total de As lançado à atmosfera (BINDER et al., 1987; MATSCHULLAT , 2000) - os 40\% restantes provêm de causas naturais (TAMAKI; FRANKENBERGER, 1992). 
O As produz efeitos no sistema respiratório (ocorre irritação nas mucosas nasais, laringe e brônquios), no sistema cardiovascular (observa-se lesões vasculares periféricas e alterações no eletrocardiograma), no sistema nervoso (alterações sensoriais e polineuropatias) e no sistema hematopoiético observa-se leucopenia, efeitos cutâneos e hepáticos. Exposições prolongadas podem provocar perfuração do septo nasal e, a longo prazo, insuficiência pulmonar, traqueobronquite e tosse crônica. Há também relação carcinogênica do As com o câncer de pele e brônquios (CAMPOS, 2005).

Berílio (Be) é um metal alcalino terroso, pertencente ao segundo grupo da Tabela Periódica (UNIVERSIDADE DE SÃO PAULO. CENTRO DE DIVULGAÇÃO CIENTÍFICA E CULTURAL DE SÃO CARLOS - USP - CDCC, 2005). Existem cerca de trinta minerais que, reconhecidamente, contêm Be. O Be tem importância industrial, na sua forma pura. Esse mineral é um silicato de berílio-alumínio, que aparece nas formas de águamarinha e de esmeralda. O Be é geralmente obtido como subproduto da extração de feldspato, lítio ou mica (UNIVERSIDADE FEDERAL DO RIO DE JANEIRO. INSTITUTO DE FÍSICA. UFRJ - IF, 2005).

Uma das forças motrizes da produção industrial de berílio tem sido precisamente a aplicação aeroespacial. A transparência do $\mathrm{Be}$ aos raios $\mathrm{X}$ torna-o um material útil para janelas de detectores de radiação. A liga de cobre-berílio tem dureza particularmente elevada e grande elasticidade. É usado em janelas para aparelhos de raio X; engrenagens (para relógios) e ferramentas antifaíscas (UNIVERSIDADE FEDERAL DO RIO DE JANEIRO. INSTITUTO DE FÍSICA. UFRJ - IF, 2005).

A inalação de pó, fumo ou vapor de berílio pode ser prejudicial à saúde. Além disso, os sais solúveis de Be podem produzir dermatite quando em contato com a pele. Não há, contudo, nenhum problema quando ingerido. Há três doenças associadas causadas por esse elemento: doença respiratória aguda, crônica e dermatites (UNIVERSIDADE FEDERAL DO 
RIO DE JANEIRO. INSTITUTO DE FÍSICA. UFRJ - IF, 2005).

Cádmio (Cd) é um metal branco acinzentado, podendo se apresentar na cor prata esbranquiçado, azulado ou metálico lustroso. É dúctil à temperatura ambiente e sua consistência é tão mole que pode ser facilmente cortado com faca (US. AGENCY FOR TOXIC SUBSTANCES AND DISEASE REGISTRY - ATSDR, 1997; MERCK, 2002).

As maiores fontes antropogênicas de Cd envolvem a mineração, produção, consumo e disposição de produtos que utilizam $\mathrm{Cd}$ (baterias de $\mathrm{Ni}-\mathrm{Cd}$, pigmentos, estabilizadores de produtos de policloreto de vinila (PVC), recobrimento de produtos ferrosos e não-ferrosos, ligas de cádmio e componentes eletrônicos); e consiste de fontes “inadvertidas”, onde o Cd é um constituinte natural do material que está sendo processado ou consumido: metais não-ferrosos, ligas de zinco, chumbo e cobre, emissões de indústrias de ferro e aço, combustíveis fósseis (carvão, óleo, gás, turfa e madeira), cimento e fertilizantes fosfatados (US. ATSDR, 1997; ORGANIZATION FOR ECONOMIC COOPERATION AND DEVELOPMENT - OECD, 1994; WHO, 1992).

O lixo urbano contém $\mathrm{Cd}$ proveniente de várias fontes, contaminando o composto orgânico, que é o produto da reciclagem da parte orgânica do lixo e o chorume, líquido, gerado no lixo e que é lançado em corpos receptores (rios), ou penetra no solo alcançando águas subterrâneas (TEVES, 2001).

Outros resíduos sólidos que também contêm $\mathrm{Cd}$, mas em proporções menores, são: cinzas da queima de combustíveis sólidos, resíduos de cimento, resíduo de lixo municipal e resíduo de esgoto. Os resíduos de lixo municipais são importantes, por ainda não existe coleta eficiente de baterias Ni-Cd (CHASIN; CARDOSO, 2003).

Portanto, o Cd é visto como poluente importante para o mundo. Ele foi revisado pela IRPTC (International Register of Potentially Toxic Chemical of United Nations Environment Program) e como resultado foi incluído na lista de substâncias e 
processos potencialmente perigosos (CHASIN; CARDOSO, 2003).

O órgão alvo primário nas exposições ao $\mathrm{Cd}$ a longo prazo é o rim. E os efeitos tóxicos após a ingestão do agente químico são os distúrbios gastrintestinais. A inalação de doses elevadas produz intoxicação aguda, caracterizada por pneumonite e edema pulmonar (CAMPOS, 2005).

Cromo (Cr) é um metal cinza-aço, com forma cristalina cúbica, sem odor e muito resistente à corrosão (SILVA, 2003).

$\mathrm{O} \mathrm{Cr}$ é um elemento geralmente abundante na crosta terrestre. Entre as fontes naturais de contaminação ambiental estão os incêndios florestais e as erupções vulcânicas (WHO, 1988).

As principais atividades humanas, nas quais o $\mathrm{Cr}$ e seus compostos são liberados para o meio ambiente, são as emissões decorrentes da fabricação do cimento, construção civil, devido aos resíduos provenientes do cimento, soldagem de ligas metálicas, fundições, manufatura do aço e ligas, indústria de galvanoplastia, lâmpadas, minas, lixos urbano e industrial, incineração de lixo, cinzas de carvão, curtumes, preservativos de madeiras e fertilizantes (WHO, 1988; US. ATSDR, 2000; HAZARDOUS SUBSTANCES DATA BANK - HSDB, 2000).

As principais fontes antropogênicas que contaminam as águas superficiais e profundas são as operações de galvanoplastia, indústrias de tingimento de couro e manufatura de tecidos. A deposição de partículas de Cr presentes no ar atmosférico é também uma fonte de exposição significativa, ainda que não identificável (US. ATSDR, 2000).

Exposição dérmica é a mais comum via de exposição industrial e inalação de soldadores e mineradores de material particulado ou fumos contendo cromo (ARFSTEN; AYLWARD; KARCH, 1998). O Cr IV está classificado como carcinógeno do grupo I pela International Agency of Research on Cancer, exposições elevadas de cromo foram associadas 
com carcinoma celular e adenocarcinoma pulmonar, e incluem ulceração e perfuração do septo nasal, irritação do trato respiratório, possíveis efeitos cardiovasculares, gastrintestinais, hematológicos, hepáticos e renais (SILVA, 2003).

Cobre (Cu) é um metal marrom avermelhado e nobre como o ouro e a prata (PEDROZO, 2003). É utilizado em ligas, manufatura de fios e condutores, galvanoplastia, utensílios de cozinha, tubulações residenciais e para linhas de serviço, manufatura de moedas, inseticida, fungicida, algicida e desinfetante, tintas antiincrustantes, baterias, eletrodos e pigmentos (GROSSI, 1993).

Do total de $\mathrm{Cu}$ utilizado anualmente no mundo, 65\% é empregado na indústria elétrica e eletrônica, cerca de $15 \%$ na construção civil e os restantes $20 \%$ em equipamentos de transporte, ar-condicionado e refrigeração, peças de equipamentos de engenharia, e domésticos, e equipamentos hidráulicos (WHO, 1998).

Numerosas são as fontes de $\mathrm{Cu}$ nos efluentes e lodos de esgoto, incluindo as excretas de humanos, a corrosão de tubulações de $\mathrm{Cu}$ nas redes hidráulicas domésticas e a adição direta decorrente de processos industriais. Assim, o uso desse material na agricultura, como método de disposição de resíduos sólidos, deve ser avaliado diante de seu potencial tóxico (PEDROZO, 2003).

$\mathrm{O} \mathrm{Cu}$ também é um metal essencial, e com isso há várias desordens no seu mecanismo de homeostase que resultam na sua deficiência ou toxicidade. Dentre elas, distúrbios genéticos de Menkes e de Wilson (PEDROZO, 2003).

A toxicidade aguda decorrente do uso de sulfato de $\mathrm{Cu}$ nas doses de 0,4 a100mg $\mathrm{Cu}$ e os sintomas apresentados foram vômitos, sensação de ardência epigástrica, diarréia, letargia, anemia hemolítica aguda, dano renal e hepático, neurotoxicidade, aumento da pressão sangüínea e freqüência respiratória. A exposição aguda a poeiras e a fumos de $\mathrm{Cu}$ pode irritar os olhos, o nariz e a garganta, provocando tosse, espirros e sangramentos nasais. 
Os fumos metálicos podem promover a febre dos fumos, caracterizada por sintomas semelhantes à gripe, associados ao sabor metálico na boca, febre e calafrios, broncoconstrição e tosse. A exposição crônica pode levar ao espessamento e esverdeamento da pele, dentes e cabelo. No nível pulmonar, pode-se observar irritação das fossas nasais, úlceras e perfuração do septo, além da hepatotoxicidade (WHO, 1998; BARCELOUX, 1999a).

Ferro (Fe) puro é um metal branco-prateado, maleável, muito reativo (KROSCHWITZ, 1995; HAZARD MANAGEMENT - HAZARDTEXT, 2000).

Entre os principais usos do Fe na indústria citam-se: indústria metalúrgica (usado como pó de ferro), indústria siderúrgica (usado na fabricação de ligas), fabricações de ímãs, tintas, pigmentos, abrasivos e compostos para o polimento e soldagem de metais (ILO, 1997; HAZARDTEXT, 2000).

Constituem fontes naturais de contaminação do Fe o desgaste natural das rochas contendo minérios de ferro, meteoritos e o escoamento superficial do metal (KROSCHWITZ, 1995). Entre as fontes antropogênicas de Fe de origem industrial estão as emissões pelas atividades de mineração, fundição, soldagem, polimento de metais e o uso de compostos de ferro como agentes antidetonantes da gasolina (INTERNATIONAL LABOUR ORGANIZATION. ILO, 1997). Entre as fontes antropogênicas de Fe de origem urbana estão os efluentes de esgotos municipais e industriais e o escoamento superficial urbano (ABUHILALAH; BRADAN, 1990). O uso de fertilizantes na agricultura é outro fator relevante de contaminação ambiental de origem antropogênica (SHARMA et al., 2000).

O Fe, elemento essencial, é componente chave na manutenção da homeostase celular. Tanto a deficiência quanto o excesso são prejudiciais ao organismo humano. A deficiência de Fe leva à anemia hipocrômica microcítica, à alteração do metabolismo muscular (GANONG, 1993; HILLMAN, 1995) e à disfunção no sistema imunológico. Já, quando ocorre a sobrecarga de Fe, ocorre o acúmulo de hemossiderina nos tecidos, 
produzindo hemossiderose e hemocromatose, que se caracteriza pela pigmentação da pele, cirrose hepática, incidência elevada de carcinoma hepático e atrofia das gônadas (GANONG, 1993).

Mercúrio (Hg) é um metal pesado de aspecto argênteo, inodoro. Na sua forma elementar, é um líquido denso, prateado, nas condições normais de temperatura e pressão.

Estima-se que as atividades de mineração mundial de $\mathrm{Hg}$ gerem de 7 a 10 mil toneladas por ano, acarretando danos ao ambiente e emissões diretas para a atmosfera. Em indústrias de cloro-álcali, as emissões são de $450 \mathrm{~g}$ de $\mathrm{Hg} /$ tonelada por ano de soda cáustica produzida (WHO, 1991).

Admite-se que, de modo geral, os produtos industriais e domésticos, tais como termômetros, baterias, dentre outros, são parte significativa das emissões de $\mathrm{Hg}$ no ambiente, tornando-se parte do lixo sólido na maioria das cidades (AZEVEDO; NASCIMENTO; CHASIN, 2003).

Em efluentes, o Hg é concentrado nos dejetos, a partir do tratamento do esgoto, por um fator de várias centenas a vários milhares acima dos níveis inicialmente presentes no esgoto bruto (HSDB, 2000).

O trato respiratório é a via mais importante de introdução do Hg. A exposição a elevadas concentrações de Hg pode provocar febre, calafrios, dispnéia, cefaléia, diarréia, câimbras abdominais e diminuição da visão. Casos severos progridem para edema pulmonar, dispnéia e cianose. As complicações incluem enfisema, pneumomediastino e morte. Destacase também gengivite, salivação, estomatite, tremor e alterações psicológicas. A síndrome é caracterizada pelo eretismo (insônia, perda de apetite, perda da memória, timidez excessiva, instabilidade emocional), e pode ocorrer também disfunção renal (CAMPOS, 2005).

Manganês (Mn) pode se apresentar como um sólido, frágil, quebradiço, lustroso, ou pó branco-acinzentado (WHO, 1981; BARCELOUX, 1999b). O Mn e seus compostos têm 
uma variedade de usos. O Mn metálico (ferromanganês) é usado principalmente na produção do aço. O dióxido de manganês é utilizado na produção de baterias, palitos de fósforo, porcelanas e materiais à base de vidro. O sulfato de manganês é utilizado como fertilizante, usado na fabricação de cerâmicas e fungicidas. O permanganato de potássio é um pó oxidante utilizado como desinfetante, agente antialgas, agente de limpeza de metais e conservante de folhas e frutas secas (US. ATSDR, 2000).

A principal fonte de exposição da população geral ao Mn em humanos é através do consumo dos alimentos, pois vegetais, grãos, frutas são ricos em manganês (GOYER, 1996).

O Mn é usado na fabricação de ligas de ferromanganês e de ferrossiliciomanganês, eletrodos para solda, fósforos de segurança, cerâmicas etc. A exposição ocupacional por inalação de poeiras de Mn pode ser de: exposição aguda, resultando a uma exposição crônica, chamada manganismo, após inalação crônica de dióxido manganês por períodos superiores a dois anos. O manganismo produz doença neuropsíquica caracterizada por irritação, dificuldade em caminhar, alteração da fala, comportamento compulsivo etc. (GOYER, 1996). A exposição a altas concentrações ambientais de Mn pode originar inflamação nos pulmões (pneumonia química), e efeitos como tosse seca, náusea, dor de cabeça, fadiga, dispnéia, após exposição a altas concentrações de óxido de manganês (BARCELOUX, 1999b). Os alvos primários após exposições crônicas ao Mn são os pulmões e o cérebro. O manganismo se inicia com sintomas inespecíficos e sinais neurológicos subclínicos, que incluem anorexia, apatia, artralgias, astenia, irritabilidade, letargia e fraqueza nas extremidades. Gradualmente, tremores, mudança na expressão facial e distúrbios na comunicação, e finalmente, há o desenvolvimento de condições clínicas graves como o mal de Parkinson (MARTINS, 2003).

Níquel (Ni) é um metal prateado, que ocorre naturalmente na crosta terrestre (SNOW; COSTA, 1992). É um elemento razoavelmente duro, com fraco brilho amarelado. É 
dúctil e maleável (SUNDERMAN JR. et al., 1987).

O Ni atmosférico existe principalmente na forma de aerossóis, ocasionados por queimadas que produzem fumaça contendo partículas do metal (WHO, 1991).

A utilização do $\mathrm{Ni}$ e de seus compostos na indústria é muito diversificada, a aplicação mais importante é na fabricação do aço inoxidável (SUNDERMAN JR. et al., 1989). É utilizado também na fabricação da margarina e manteiga, a partir de gorduras líquidas (OLIVEIRA, 2003). Os compostos inorgânicos apresentam as seguintes outras utilizações: produção de ligas de Ni, produção de Ni fundido com ferro, catálise, manufatura de baterias alcalinas (Ni-Cd), manufaturas de moedas, pigmentos inorgânicos, próteses clínicas e dentárias (MUSHAK, 1980).

As fontes globais de Ni a partir da atividade antrópica são: resíduo da combustão de óleo, combustão de óleo combustível, mineração e refinaria de $\mathrm{Ni}$, incineradores municipais, produção de aço, gasolina e combustão de óleo diesel, produção de liga de níquel, queima de carvão vegetal, produção de moldes de ferro, incineração de lodo e produção liga de cobre-níquel (WHO, 1991).

A principal forma de contaminação do solo pelo homem se dá pelas emissões das atividades de fusão e refino do metal e pela disposição final do lodo contaminado. A deposição do Ni atmosférico no solo, bem como a disposição de resíduos, através da aplicação de fertilizantes, apresenta emissões da ordem de $5,5 \times 10^{4}$ e $1,4 \times 10^{4} \mathrm{~kg} / \mathrm{ano}$, respectivamente (NRIAGU, 1991).

Os principais efeitos nocivos da exposição ocupacional ao Ni são: alergia (PETERS; GAMMELGAARD; MENNÉN, 1991), rinite e sinusite, câncer das cavidades nasais, do pulmão e de outros órgãos (SUNDERMAN JR. et al., 1988; SNOW; COSTA, 1992).

Chumbo (Pb) é um metal cinza-azulado, sem odor, maleável, sensível ao ar. $\mathrm{O} \mathrm{Pb}$ 
tetraetila e o tetrametila são exemplos importantes de compostos orgânicos sintetizados industrialmente em que o metal aparece ligado ao carbono. São usados como aditivos em combustíveis, sendo, portanto, fontes de contaminação ambiental. Ambos são líquidos incolores (WHO, 1989).

$\mathrm{O} \mathrm{Pb}$ metálico é usado na forma de lâmina ou canos, em indústrias químicas e da construção. É usado também como ingrediente na solda e em material de revestimento na indústria automotiva. É um valioso material protetor contra radiações ionizantes. É empregado como metalizante para coberturas protetoras, na manufatura de baterias e como um banho de tratamento quente em revestimento de cabos. Está presente numa variedade de ligas e seus compostos são preparados e usados em grande escala em muitas indústrias. Cerca de $40 \%$ do chumbo são usados como um metal, $25 \%$, em ligas e $35 \%$, em compostos químicos (PARMEGGIANI, 1983; US. ATSDR, 1999).

Os óxidos de chumbo são usados nas placas de baterias elétricas e acumuladores, como agentes componentes na manufatura da borracha, como ingredientes nas tintas e como constituintes de vitrificados, esmaltes e vidros (US. ATSDR, 1999).

$\mathrm{O}$ arseniato de chumbo pode ser usado como inseticida, o sulfato de chumbo como composto na borracha, o acetato de chumbo tem importante emprego na indústria química, o naftenato de chumbo é usado como secante e o chumbo tetraetila, um aditivo antidetonante para gasolina (US. ATSDR, 1999).

A relação chumbo-síndrome associada ao sistema nervoso central depende do tempo e da especificidade das manifestações. Destaca-se a síndrome polineurítica (alterações sensoriais, perceptuais e psicomotoras), síndrome astênica (fadiga, dor de cabeça, insônia, distúrbios durante o sono e dores musculares), síndrome hematológica (anemia hipocrômica moderada), síndrome renal (nefropatia não específica, proteinúria, aminiacidúria, diminuição da depuração da uréia e do ácido úrico), síndrome do trato gastrintestinal (cólicas, anorexia e 
diarréia), síndrome cardiovascular (miocardite crônica, alterações no eletrocardiograma, palidez facial ou retinal e hipertensão) e síndrome hepática (interferência de biotransformação) (CAMPOS, 2005).

Estanho (Sn) é maleável e prateado (CCDC, 2005). Como metal puro, o Sn é usado na construção de tubos e válvulas, no fabrico de recipientes para água destilada, cerveja e bebidas carbonatadas. Pode, ainda, ser usado em tanques de armazenamento de soluções químicas farmacêuticas, em eletrodos de condensadores, fusíveis, munições, papel metalizado para envolver alimentos, doces ou tabaco etc. O pó de Sn é usado no fabrico desses papéis e de tintas e sprays. A galvanoplastia é outra importante aplicação do Sn, podendo ser feita a eletrodeposição em torno de peças de aço, cobre, alumínio etc. As peças estanhadas têm inúmeras aplicações tais como em utensílios de cozinha, recipientes de sprays e creme para a barba, latas de tinta, componentes eletrônicas, circuitos impressos, clipes, pinos e muitas outras. Podem ser usados, também, objetos estanhados para efeitos decorativos (UFRJ - IF, 2005).

Os compostos de estanho mais importantes são o óxido estânico $\left(\mathrm{SnO}_{2}\right)$, usado em resistências elétricas e dielétricas, e o óxido estanhoso que se usa no fabrico de sais estanhosos para galvanoplastia e como reagentes químicos. Os estanhatos de chumbo, bário, cálcio e cobre são indispensáveis na manufatura de condensadores elétricos. O fluoreto estanhoso é usado como aditivo em pastas dentífricas. Alguns compostos orgânicos de estanho encontram aplicação como fungicidas e inseticidas para a agricultura e, ainda, como preservantes de madeira, têxteis e papel (UFRJ - IF, 2005).

Tálio (Tl) é um elemento metálico cinzento, pertencente ao grupo do boro na Tabela Periódica (USP. CDCC, 2005). O Tl e os seus compostos são usados em inseticidas e venenos para roedores. O sulfato de tálio é um composto insípido e inodoro, podendo ser adicionado à glicerina, ao açúcar ou à água para eliminar pequenos roedores e insetos. É 
utilizado, ainda, em aplicação de Tl em ligas metálicas, como, por exemplo, o tálio-chumbo que é usada em certos tipos de fusíveis (UFRJ - IF, 2005). É utilizado também como aditivo de vidros especiais, usados no encapsulamento de semicondutores, condensadores e outros dispositivos eletrônicos. O manuseamento do $\mathrm{Tl}$ deve ser feito com bastante cuidado, para evitar os seus efeitos tóxicos. Quando em contato com o ar ou a água, o metal forma rapidamente compostos solúveis, relativamente tóxicos. Os sintomas de envenenamento com Tl são a rápida perda de cabelo bem como distúrbios gastrintestinais e nervosos (UFRJ - IF, 2005).

Vanádio (V) é um elemento metálico de transição, prateado (USP. CCDC, 2005). O vanádio encontra-se bastante disperso na natureza, inclusive em carvões e em petróleos brutos (UFRJ - IF, 2005).

Os seus compostos mais importantes são o pentóxido e o metavanadato de amônio, que são utilizados como catalisadores na indústria química, em particular na fabricação de ácido sulfúrico. Forma também ligas, em particular, com o ferro, aditivo para o aço, ao qual confere propriedades mecânicas e de resistência especialmente interessantes. Outra liga de interesse é a formada com o alumínio, útil para a preparação de ligas de titânio, vanádio e alumínio, usadas na indústria aeronáutica (UFRJ - IF, 2005).

$\mathrm{O} \mathrm{V}$ não tem funções biológicas definidas nos animais, mas encontra-se no pigmento respiratório que constitui o sangue (azul) de um tipo de vermes marinhos. O vanádio pode também substituir o fósforo na molécula da apatita $\left(\mathrm{P}_{2} \mathrm{O}_{5}\right)$, que é um importante constituinte dos dentes. $\mathrm{O} \mathrm{V}$ e os seus compostos devem ser encarados como materiais tóxicos, devendo, por isso, ser tratados e manipulados com bastante cuidado (UFRJ - IF, 2005).

Zinco (Zn) elementar é um metal branco-azulado brilhante (BUDAVANI, 1996). Os compostos de Zn são muito utilizados na indústria e não são explosivos ou inflamáveis. 
São utilizados na produção de tintas brancas, de cerâmicas e de vários outros produtos. O óxido de zinco é também usado para produzir borracha. Outros compostos, como acetato de zinco, cloreto de zinco e sulfato de zinco são usados na preservação de madeira e no tingimento de tecidos. O cloreto de zinco é o maior constituinte presente na fumaça de bombas. Compostos de Zn são também usados na indústria de medicamentos, na produção de bloqueadores solares, desodorantes, preparações para tratamento de micoses, acne e xampus anticaspa (US. ATSDR, 1994).

O Zn é um metal essencial, portanto, tanto a ausência quanto a exposição excessiva podem trazer efeitos nocivos. Uma dieta inadequada com deficiência de zinco associada às doenças hepáticas, geradas por alcoolismo crônico, pode estar associada a dermatites, à cegueira noturna, à atrofia testicular, à impotência, à doença renal crônica e à anemia hemolítica. E, após exposição aguda por intensa inalação de óxidos de zinco, aparecem, em poucas horas, secura na garganta, tosse, dor subesternal e dispnéia (GOYER, 1996). Em exposições a altas concentrações de fumaça de cloreto de zinco os efeitos incluem: dispnéia, dor pleurítica, pneumotórax, pneumonite aguda pela irritação do trato respiratório e irritação da conjuntiva e da córnea (US. ATSDR, 1994).

\subsection{Sistema de tratamento de esgoto por lodos ativados}

O processo de lodos ativados foi desenvolvido na Inglaterra, em 1914, por Ardern e Lockett. Consiste basicamente na introdução da matéria orgânica em um tanque, onde uma cultura de bactérias aeróbias é mantida em suspensão, sob determinadas condições, de forma a degradar a matéria orgânica (MIGUEL et al., 2004).

Após um período pré-determinado de tempo, a mistura é encaminhada a um decantador secundário, onde o lodo é separado do esgoto tratado. Uma parte do lodo 
decantado retorna ao tanque de aeração para manter a concentração de microorganismos no tanque (SÃO PAULO. SECRETARIA DE ENERGIA, RECURSOS HÍDRICOS E SANEAMENTO. SABESP, 2005).

O lodo ativado é formado principalmente de bactérias, fungos, protozoários, rotíferos e nemátodos, sendo as bactérias os microorganismos de maior importância. O processo de tratamento é biológico e a matéria orgânica é estabilizada pela oxidação bacteriológica (aeróbia e anaeróbia) e/ou redução fotossintética das algas (MIGUEL et al., 2004).

O sistema de lodos ativados exige alto grau de mecanização e elevado consumo de energia elétrica. O tanque de aeração ou reator, o tanque de decantação e a recirculação de lodo são partes integrantes desse sistema. $\mathrm{O}$ efluente passa pelo reator, onde ocorre a remoção da matéria orgânica e depois pelo decantador, de onde sai clarificado, após a sedimentação dos sólidos (biomassa) que formam o lodo de fundo. Esse é formado por bactérias, ainda ávidas por matéria orgânica, que são enviadas novamente para o reator (através da recirculação de lodo). Com isso, há aumento da concentração de bactérias em suspensão no tanque de aeração. Para se ter uma idéia, essa é mais de 10 vezes maior do que a de uma lagoa aerada de mistura completa sem recirculação. Porém, uma taxa equivalente ao crescimento das bactérias (lodo biológico excedente) deve der retirada, pois, se fosse permitido que as bactérias se reproduzissem continuamente, alguns problemas poderiam ocorrer. A presença de biomassa no efluente final, devido à dificuldade de sedimentação em um decantador secundário sobrecarregado e a dificuldade de transferência de oxigênio para todas as células no reator são exemplos destes (SÃO PAULO. SABESP, 2005).

Na Figura 3, são descritos os principais microorganismos utilizados no tratamento de esgotos por lodos ativados. 

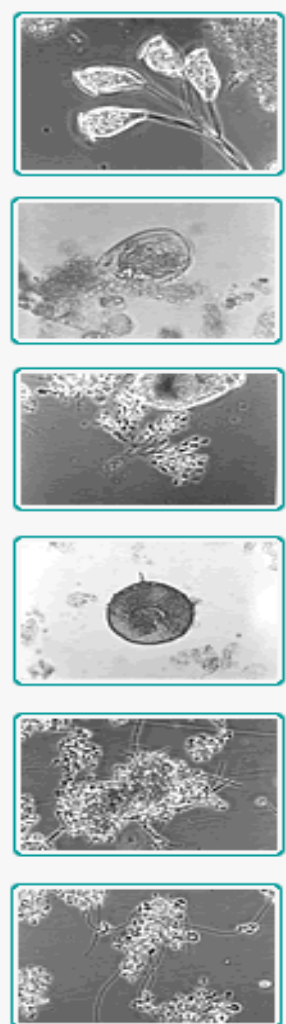

Ciliado fixo - protozoário ciliado de hábito alimentar filtrador, comum na comunidade dos lodos ativados.

Euplotes sp. - ciliado predador de flocos de lodo ativado, alimenta-se das bactérias que constituem o floco de lodo ativado, contribuindo para a renovaçẫo da comunidade bacteriana.

Poteriodendron sp. - Colônia de flagelados.

Centropyxis sp. - Tecameba (ameba que secreta ou constrói uma carapaça), também comum no sistema de lodos ativados.

Floco born - exemplo de floco de lodo ativado.

Formado por bactérias viáveis, bactérias mortas, material particulado orgânico e inorgânico.

Levernente curvado - os "fiozinhos" na foto sẫo colônias de bactérias filamentosas, cuja ausência ou crescimento em demasia prejudica a eficiência do tratamento, por causar perda de sólidos pelo efluente final.

Figura 3 - Bactérias, protozoários e micrometazoários encontrados no sistema de lodos ativados.

Fonte - São Paulo. Secretaria de Energia, Recursos Hídricos e Saneamento - SABESP, 2005

Além da matéria orgânica carbonácea, o sistema de lodos ativados pode remover também nitrogênio e fósforo; porém, a remoção de coliformes é geralmente baixa devido ao pequeno tempo de detenção hidráulico e normalmente insuficiente para o lançamento no corpo receptor.

Segundo a SABESP (SÃO PAULO. SABESP, 2005), a escolha do sistema de tratamento é função das condições estabelecidas para a qualidade da água dos corpos receptores. Além disso, qualquer projeto de sistema deve se basear no conhecimento de diversas variáveis do esgoto a ser tratado tais como a vazão, o pH, a temperatura, o DBO etc. 
O sistema de lodos ativados possui algumas variantes, tais como as indicadas abaixo.

\section{Sistema de lodos ativados convencional}

O sistema de lodos ativados convencional é constituído por reator e decantadores primário e secundário. Esse sistema possui decantador primário para que a matéria orgânica em suspensão sedimentável seja retirada antes do tanque de aeração, gerando assim economia no consumo de energia. O tempo de detenção hidráulico é bem baixo, da ordem de 6 a 8 horas e a idade do lodo em torno de 4 a 10 dias. Como o lodo retirado ainda é jovem e possui grande quantidade de matéria orgânica em suas células, há necessidade de uma etapa de estabilização do lodo (VON SPERLING, 1997). A ETE- Ribeirão Preto e a ETE-Franca são exemplos de ETEs que utilizam esse tipo de sistema para tratar esgotos domésticos.

\section{Sistema de lodos ativados de aeração prolongada (fluxo contínuo)}

A diferença desse sistema para o sistema convencional é que a biomassa permanece mais tempo no reator (18 a 30 dias), porém, continua recebendo a mesma carga de DBO. Por isso, o reator terá que possuir maiores dimensões e, conseqüentemente, existirá menor concentração de matéria orgânica por unidade de volume e menor disponibilidade de alimento. Para sobreviver, as bactérias passam a consumir a matéria orgânica existente em suas células em seus metabolismos. Assim, o lodo já sairá estabilizado do tanque de aeração, não havendo necessidade de se ter um biodigestor. Esse sistema, também, não possui decantador primário, para evitar a necessidade de uma unidade de estabilização do lodo resultante desse.

Como a estabilização do lodo ocorre de forma aeróbia no reator, há maior consumo de energia elétrica. Porém, esse é um sistema de maior eficiência de remoção de DBO dentre aqueles que funcionam com lodos ativados (VON SPERLING, 1997). Exemplos de estação de tratamento de esgotos domésticos, que funciona segundo o sistema de lodos ativados por aeração prolongada, são a ETE-Caiçara (em Ribeirão Preto) e ETE-Luiza. 


\section{Sistema de lodos ativados de fluxo intermitente (batelada)}

Nesse sistema, há apenas uma unidade e todas as etapas de tratamento do esgoto ocorrem dentro do reator. Essas passam a ser seqüências no tempo e não mais unidades distintas. A biomassa permanece no tanque, não havendo necessidade de sistema de recirculação de lodo. Um sistema de lodos ativados de fluxo intermitente possui ciclos bem definidos de operação. São eles: enchimento, reação, sedimentação, esvaziamento e repouso. Em sistemas que recebem esgotos de forma contínua como, por exemplo, as estações que recebem esgotos domésticos há a necessidade de se ter mais de um tanque de aeração trabalhando em paralelo. Pois, um tanque que está no ciclo de decantação não pode receber esgotos e para isso deve haver um outro tanque que esteja no ciclo de enchimento. Esse sistema pode funcionar tanto como um de lodos ativados convencional como um de aeração prolongada (VON SPERLING, 1997).

\subsection{Lodo de esgoto: caracterização e destinação}

A caracterização do lodo de esgoto é uma condição básica para determinação do processo de tratamento que esse deve ser submetido para sua transformação em fertilizante e, principalmente, uma forma de adequá-lo para o atendimento às restrições impostas pela legislação. O lodo de esgoto deve atender a certas orientações sobre macro e micronutrientes, teor de metais e patógenos, sendo os nutrientes a característica menos significativa, sob o ponto de vista restritivo por se tratar dos elementos básicos para a nutrição das plantas. $\mathrm{Na}$ prática, os nutrientes simplesmente são balanceados conforme o NPK (Nitrogênio - Fósforo Potássio), requerido pelas plantas e qualidade do solo. Não se deve descartar o cuidado na quantidade máxima de aplicação para cada cultura, pois o excesso não absorvido também é prejudicial, e por decomposição biológica no solo ou na água dão lugar a amônia, nitratos, 
fosfatos e ainda comprometem o pH do solo e sua salinização (WESTPHALEN et al., 2004).

No caso do lodo de esgoto, os componentes perigosos são os metais pesados: sua absorção pelas plantas pode prejudicar a saúde dos animais e do homem por bioacumulação de modo indireto, as bactérias, vírus, protozoários e helmintos. A descarga desses componentes, bem como a dos nutrientes nitrogênio e fósforo na superfície e no lençol freático, deve ser minimizada para que se evite a degradação da qualidade das águas (SANTOS, 1996).

Na verdade, a grande concentração de metais pesados no biossólido tem sua origem em processos industriais. $\mathrm{O}$ controle da concentração dos despejos deve estar diretamente relacionado ao número de indústrias e não somente ao despejo individual. A quantidade e a qualidade do lodo produzido variam de lugar para lugar, dependendo dos processos de tratamento dos lodos, da sua secagem (um lodo seco ainda contém $50 \%$ de umidade) e, ainda, da população contribuinte e/ou dos efluentes industriais que por ventura são lançados na rede coletora, formando significante parcela dos esgotos municipais (CHAGAS, 2000).

Os biossólidos contêm matéria orgânica, macro e micronutrientes que exercem papel fundamental na produção agrícola e na manutenção da fertilidade do solo. Além disso, a matéria orgânica contida no biossólido pode aumentar o conteúdo de húmus, que melhora a capacidade de armazenamento e de infiltração da água no solo, aumentando a resistência dos agregados e reduzindo a erosão (WESTPHALEN et al., 2004).

O lodo de esgoto pode apresentar, em sua composição, elementos químicos e biológicos indesejáveis do ponto de vista ambiental, ou seja, pode conter elementos que, em contato com o homem e com a fauna e flora, podem causar doenças e contaminações diversas. Portanto, qualquer decisão sobre o destino final mais apropriado para o lodo de esgoto depende da avaliação e minimização dos riscos de contaminação do ambiente e do homem 
(CHAGAS, 2000).

Dentre os diferentes contaminantes do lodo de esgoto, os metais pesados representam um grupo de poluentes que requer tratamento especial, pois não são degradados biologicamente ou quimicamente de forma natural, principalmente em ambientes terrestres e em sedimentos aquáticos. Ao contrário, são acumulados e podem se tornar ainda mais nocivos quando reagem com alguns componentes dos solos e sedimentos. A matéria orgânica do solo exerce função nutricional importante no crescimento das plantas, como fonte de micronutrientes. As substâncias húmicas, matéria orgânica em determinado estágio de degradação, possuem grupos funcionais em sua estrutura molecular que lhes inferem excepcional reatividade para formar complexos metálicos (JORDÃO et al., 1993).

É necessário que o teor desses elementos no lodo seja constantemente monitorado. Por outro lado, o possível comportamento dos metais pesados nas áreas de aplicação deve ser estudado e monitorado na fase pós-distribuição do lodo (WESTPHALEN et al., 2004).

A disposição em aterros tem sido amplamente praticada, podendo ser em aterros exclusivos ou co-disposição com lixo urbano. Nos EUA e em vários países da Europa utilizase a secagem térmica prévia dos lodos, sendo seu uso freqüente na agricultura. Os lodos também são aproveitados na agricultura na forma de tortas desidratadas, conforme são obtidos nas ETEs. A incineração é praticada em fornos incineradores. Nos EUA, essa forma é geralmente praticada em regiões mais frias no norte do País. A disposição oceânica dos lodos vem sendo reduzida em países do primeiro mundo e substituída pelo uso na agricultura, como nos EUA e Espanha. Aproximadamente 16\% dos lodos gerados no Japão são usados na agricultura, áreas verdes e na construção. A incineração no Japão é usada extensivamente: $61 \%$ do lodo gerado é incinerado (MIGUEL et al., 2004).

A estabilização alcalina compreende uma tecnologia de melhoria da qualidade dos lodos e corresponde à adição de cal em quantidade suficiente para elevar o pH e estabilizar os 
lodos. Obtém-se um produto isento de patógenos, cuja destinação final pode ser a agricultura. Essa solução, no entanto, não reduz a quantidade de lodo, ao contrário, aumenta, pois, além do volume de lodo, soma-se o volume de cal (CHAGAS, 2000).

No Estado de São Paulo, procura-se resolver o problema da destinação final desses lodos a partir da elaboração e implementação do Plano de Ação de Longo Prazo (PALP) que consiste do equacionamento da destinação final dos lodos até o horizonte de 2015 , incluindo o estudo de tecnologias alternativas ao aterro, visando o aproveitamento dos lodos em usos consultivos (uso agrícola como fertilizantes, insumos na fabricação de materiais para construção civil e outros), e/ou redução do volume através de incineração (MIGUEL et al., 2004).

Os maiores problemas relativos à aplicação do lodo são devidos à sua aceitação pelo público, aos patógenos, aos riscos de contaminação do aqüífero freático pela sobrecarga de nutrientes, à diminuição do seu aproveitamento pelas concentrações excessivas de metais pesados e aos riscos de contaminação da cadeia alimentar por elementos tóxicos (SANTOS, 1996).

Conforme o Plano Diretor de Lodos da Região Metropolitana de São Paulo (RMSP), a disposição dos Lodos das ETEs em aterros sanitários pode ser efetuada tanto com resíduos sólidos urbanos, como em aterros exclusivos. A co-disposição com esses resíduos sólidos urbanos apresentam o inconveniente de reduzir a vida útil dos aterros; sendo que esse aspecto é potencializado em regiões metropolitanas, como é o caso de São Paulo (MIGUEL et al., 2004).

A solução vem sendo praticada desde outubro de 1994, quando foi firmado termo de cooperação técnica entre a SABESP e a Prefeitura do Município de São Paulo (PMSP). Assim, a PMSP recebe em dois de seus aterros, Bandeirantes e São João, o material gradeado, lodo desidratado e areia das ETEs Barueri e Suzano, desde que o peso das tortas não 
ultrapasse $5 \%$ do peso dos resíduos urbanos dispostos e a umidade não supere $60 \%$. Trata-se de solução de emergência e temporária, que visa equacionar o problema atual de disposição dos lodos. A solução de aterro exclusivo é a que deve ser considerada como solução mais adequada e duradoura. Entretanto, o encaminhamento dessa solução depara com condicionantes específicos da inexistência de áreas na RMSP com características requeridas que comportem a implantação de um aterro nos moldes necessários. Em vista do exposto, o estudo de aterro exclusivo para os lodos de ETEs da RMSP mereceu análise minuciosa e uma concepção geral para o seu desenvolvimento (MIGUEL et al., 2004).

Os diferentes sistemas de tratamento e seus respectivos estágios geram lodos com características e quantidades variáveis. De forma genérica, os decantadores primários produzem de 2500 a 3500 litros de lodo por milhão de litros de esgoto tratado que é removido por gravidade e contém de 3 a $7 \%$ de sólidos contendo de 60 a $80 \%$ de matéria orgânica. Os tratamentos secundários promovem o incremento da atividade microbiana aeróbia e/ou anaeróbia, de forma a converter os sólidos dissolvidos em sólidos suspensos (biomassa microbiana) e reduzir o conteúdo da matéria orgânica pela sua respiração. Posteriormente, a biomassa microbiana é precipitada junto com outras partículas, produzindo o lodo secundário (PARANÁ. COMPANHIA DE SANEAMENTO DO PARANÁ. SANEPAR, 1997).

Os processos aeróbios produzem de 15 a 20 mil litros de lodo por milhão de litros de esgoto tratado, que contém tipicamente 0,5 a $2 \%$ de sólidos, contendo de 50 a $60 \%$ de matéria orgânica. Os processos anaeróbios, em geral, produzem quantidades menores de lodo. A produção de lodo é variável em função do tipo de tratamento adotado; no Brasil, sistemas aeróbios de lodo ativado produzem $37 \mathrm{~g}$ de lodo por dia para cada habitante, enquanto que sistemas anaeróbios apenas $15 \mathrm{~g}$ de lodo/hab/dia (OUTWATER, 1994).

Estimativa teórica do potencial de produção de lodo de esgoto no Brasil, 
considerando apenas o tratamento integral do esgoto atualmente coletado (que beneficia aproximadamente $35 \%$ da população) produziria de 2,5 a $3,5 \times 10^{4} \mathrm{~m}^{3}$ de lodo primário (com 3 a $7 \%$ de sólidos $)$ e de 15 a $20 \times 10^{4} \mathrm{~m}^{3}$ de lodo secundário com $(0,5$ a $20 \%$ de sólidos $)$ (PARANÁ. SANEPAR, 1997).

No processo de produção do lodo, junto com as partículas minerais e a matéria orgânica, também precipitam (diretamente ou adsorvido a partículas maiores) elementos-traço com potencial tóxico e diferentes agentes patogênicos como ovos de helmintos, cistos de protozoários e colônias de bactérias. Os lodos são, em geral, ricos em matéria orgânica, nitrogênio, fósforo e micronutrientes, o que possibilita o seu uso na agricultura como fertilizante, desde que devidamente avaliados e equacionados os riscos potenciais, definidos pelos elementos-traço, agentes patogênicos e pelo nível de estabilização do material, que pode ocasionar problemas de odor e a conseqüente atração de vetores (ANDREOLI et al., 1998).

Em muitos países, e mesmo em alguns Estados do Brasil, a presença de metais pesados é um dos entraves mais fortes à reciclagem agrícola do lodo de esgoto. Em pequenas quantidades, alguns desses elementos são benéficos e indispensáveis para o desenvolvimento vegetal e/ou animal, no entanto em quantidades superiores podem ser tóxicas e, ao contrário dos patógenos e dos compostos orgânicos usuais no lodo, podem acumular no solo (BERTON, 2000).

Devido às poucas certezas sobre o comportamento desses elementos no meio edáfico (MATIAZZO-PREZOTTO; GLÓRIA, 2000), os níveis adicionados aos solos através dos lodos, devem ser rigorosamente controlados, particularmente sob condições de clima tropical, próprio do Brasil como um todo, caracterizado pela alta velocidade de degradação de materiais orgânicos e por não se ter disponíveis estudos suficientes sobre o comportamento dos metais aplicados através de resíduos. 


\subsection{Sistemas de esgotamento sanitário no município de Ribeirão Preto-SP}

O município de Ribeirão Preto está localizado na região nordeste do Estado de São Paulo. Atualmente, possui população de cerca de 504923 habitantes e área de $651 \mathrm{~km}^{2}$ (IBGE, 2002). Possui cerca de 1300 indústrias e todas as 135 mil residências recebem água encanada, sendo 97\% delas ligadas à rede coletora de esgoto. A região, que tem os maiores índices de desenvolvimento econômico e social de São Paulo, produz 70\% do suco de laranja exportado e $20 \%$ do açúcar consumido pelo Brasil (SERVIÇOS AMBIENTAIS DE RIBEIRÃO PRETO. AMBIENT, 2005).

O Serviço de abastecimento de água em Ribeirão Preto teve início em 1903, realizado por uma empresa privada - Empresa de Água e Esgotos de Ribeirão Preto S.a , que obteve junto ao município a concessão para explorar o serviço de águas e esgotos. Em 1955, a empresa não cumpriu o acordo, a prefeitura assumiu a execução dos serviços e passou a se chamar SAE (Serviço de Água e Esgotos). Em 1960, a Lei nº 968 criou o DAET (Departamento de Água, Esgotos e Telefonia) (AMBIENT, 2005).

Desde 1974, o DAERP (Departamento de Água e Esgotos de Ribeirão Preto) passou a administrar os serviços de água e esgotos do município (AMBIENT, 2005). Em 1995, a empresa brasileira Rek Construtora Ltda de Kurwziel conseguiu licitação estimada em R \$ 400 milhões (por 15 anos) para implantar e operar o serviço de tratamento de esgoto em Ribeirão Preto. A Rek, que realizava a coleta de lixo na cidade, era a acionista majoritária do consórcio Ambient que tinha como parceria a empresa multinacional americana CH2MHILL, onde conseguiram a licitação. Mas, com desdobramentos políticos e com problemas técnicos, políticos e operacionais, a licitação não foi efetuada, o que colaborou para que Ribeirão Preto ficasse um tempo sem tratamento de seus esgotos domiciliares. No entanto, depois realizou-se nova licitação que prosseguiu quando as empresas espanholas Obrascón Huarte Lain S.A. 
(OHL) e a Inima Servicios Europeos de Médio Ambiente compraram 75\% das ações do consórcio. Sendo assim, deu-se continuidade ao tratamento de esgoto em Ribeirão Preto (BOMBIG, 2005).

O tratamento de esgotos, em Ribeirão Preto, iniciou-se com a Estação de Tratamento de Esgotos Caiçara - ETE Caiçara (Figura 4), no ano de 2000, na qual é tratado o esgoto doméstico proveniente dos bairros situados na bacia do córrego Palmeiras (bairros da zona leste), com capacidade para tratar $14 \%$ dos esgotos da cidade. O esgoto coletado nos bairros é levado até a caixa de chegada da ETE Caiçara, através de um coletor tronco, chamado interceptor (AMBIENT, 2005).

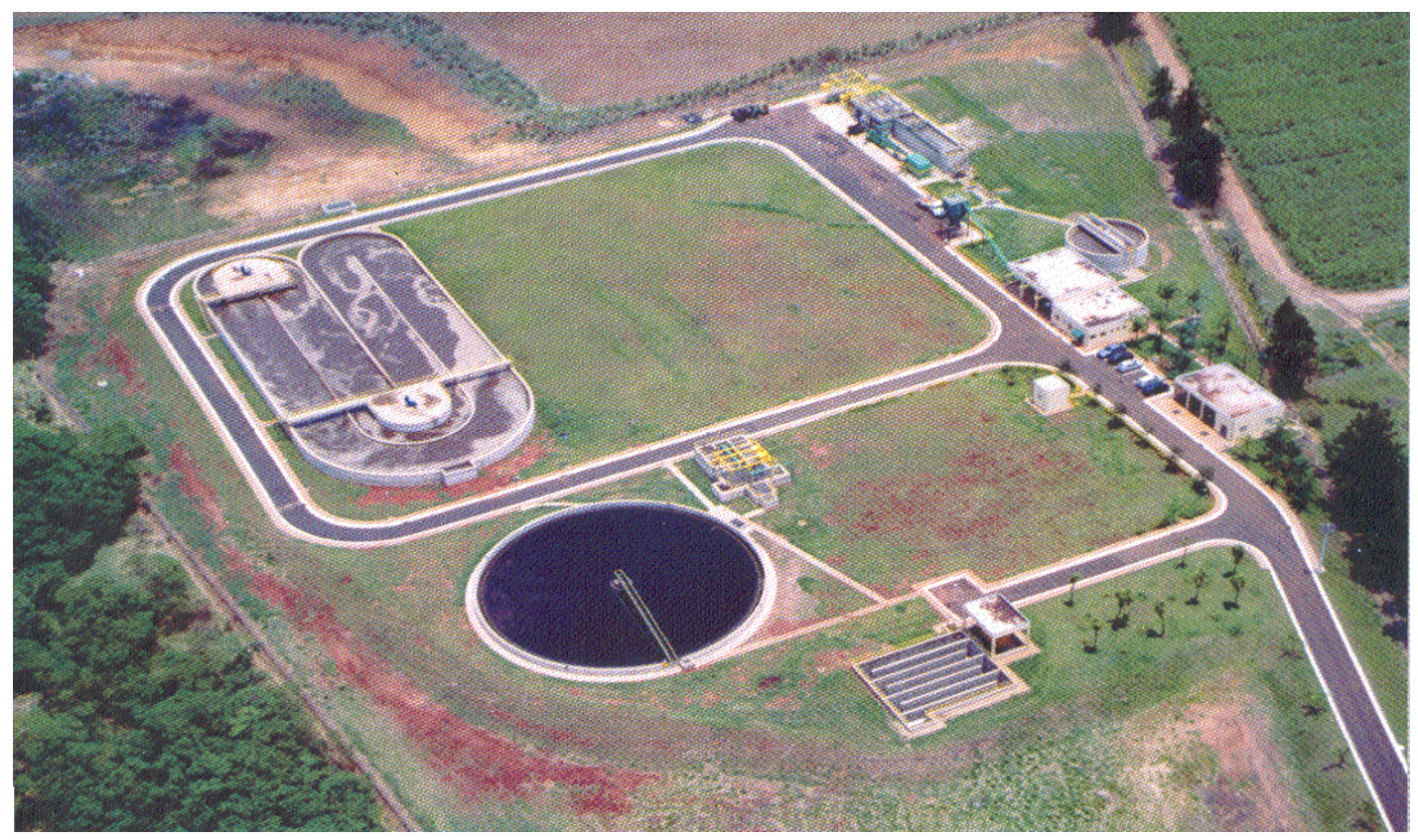

Figura 4 - Estação de tratamento de esgoto Caiçara

Na ETE Caiçara (Figura 4), a tecnologia empregada para o tratamento dos esgotos é a de lodos ativados com aeração prolongada e a capacidade nominal do sistema existente é de $526 \mathrm{~m}^{3} / \mathrm{h}$ e o volume diário médio de esgoto tratado atual é de $8.000 \mathrm{~m}^{3}$. Atualmente são atendidos 60000 habitantes. A quantidade mensal de lodo produzido é de $260 \mathrm{~m}^{3}$, sendo o 
teor médio de sólidos secos na massa de lodo de $25 \%$. O lodo produzido é destinado ao aterro sanitário e utilizado na agricultura (AMBIENT, 2005).

\section{a. Estação de tratamento de esgoto Ribeirão Preto - ETE-Ribeirão Preto}

A Estação de Tratamento de Ribeirão Preto (Figura 5), segundo a Ambient (2005), trata o esgoto doméstico proveniente dos bairros situados na bacia do Ribeirão Preto, Retiro Saudoso, Tanquinho, Laureano, Antártica, Campos e córrego de Catetos. A tecnologia utilizada é por lodos ativados convencionais, aerados por turbocompressores e difusores de membrana e sistema de digestão anaeróbica de lodos de alta carga. A ETE-Ribeirão Preto futuramente quer receber e tratar cerca de $84 \%$ do esgoto gerado em Ribeirão Preto. Início da operação em novembro de 2002. 


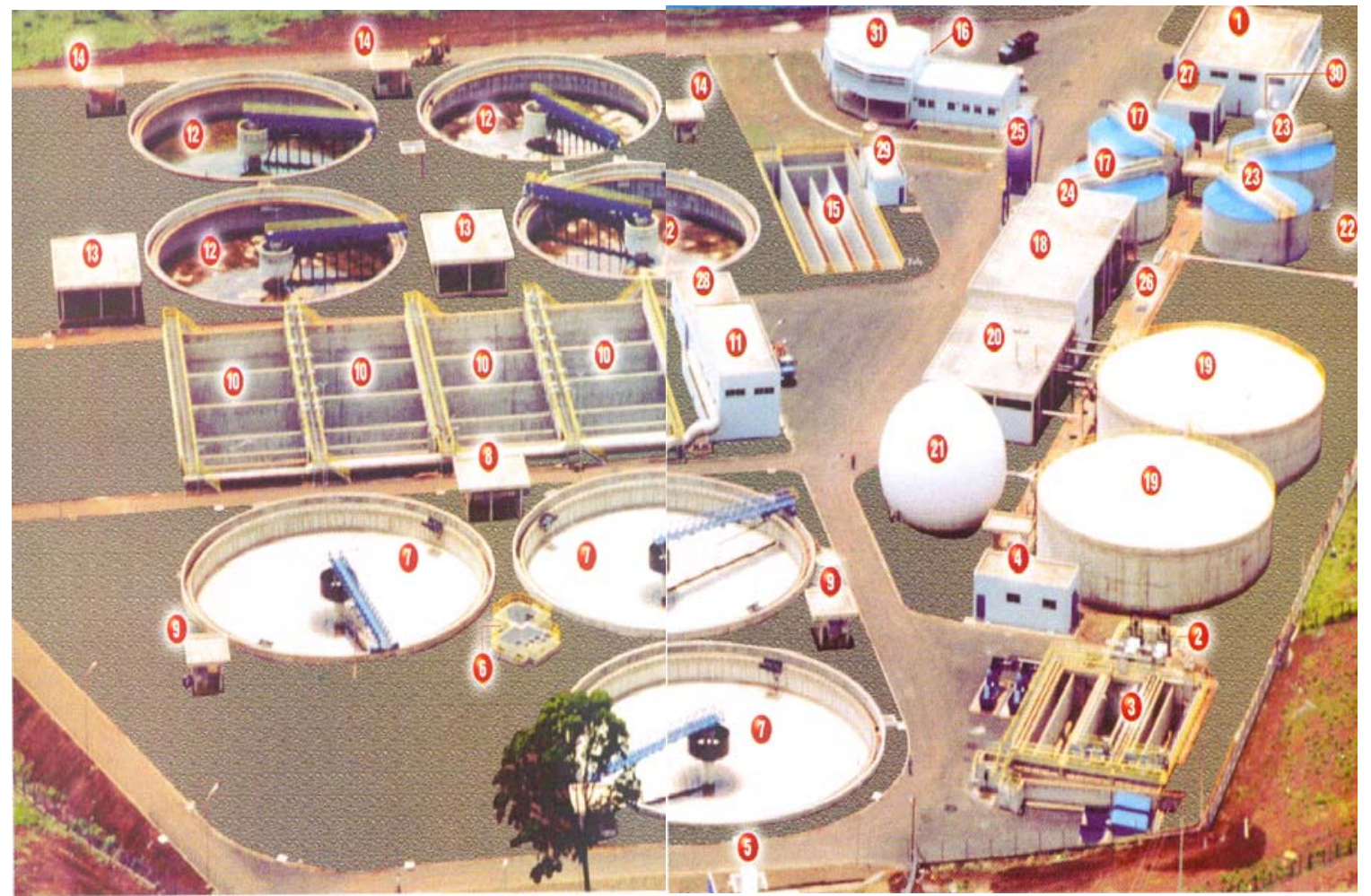

1. Chegada e bombeamento de água bruta

2. Desbaste de partículas grossas e finas

3. Desarenador e desengordurador

4. Sopradores

5. Medidor de vazão eletromagnético

6. Caixa de distribuição

7. Decantação primária

8. Bombeamento de lodos primários

9. Bombeamento de flutuantes primários

10. Reator biológico

11. Prédio turbocompressores

12. Decantação secundária

13. Bombeamento de lodos secundários

14. Bombeamento de flutuantes secundários

15. Câmara de cloração

16. Fonte de saída
17. Espessadores de gravidade

18. Espessadores por flotação

19. Digestores anaeróbicos

20. Sist. agitação e aquecimento dos digestores

21. Gasômetro de membrana

22. Tocha

23. Depósito tampão

24. Desidratação de lodos

25. Sítio de estocagem de lodos desidratados

26. Galeria de serviços

27. Centro de transformação $n^{\circ} 1$

28. Centro de transformação $n^{\circ} 2$

29. Bombeamento de água de serviços

30. Sistema de desodorização

31. Prédio de controle

Figura 5 - Etapas da estação de tratamento de esgoto por lodos ativados de Ribeirão Preto

O esgoto coletado na cidade é levado por gravidade, através de interceptores, até o Poço de Grossos da ETE (Figura 6; ponto 1 da Figura 5), onde são retirados os sólidos grosseiros sedimentados com o auxílio de um guindaste. Os resíduos sólidos são, 
posteriormente, enviados a um aterro sanitário do município de Ribeirão Preto-SP.

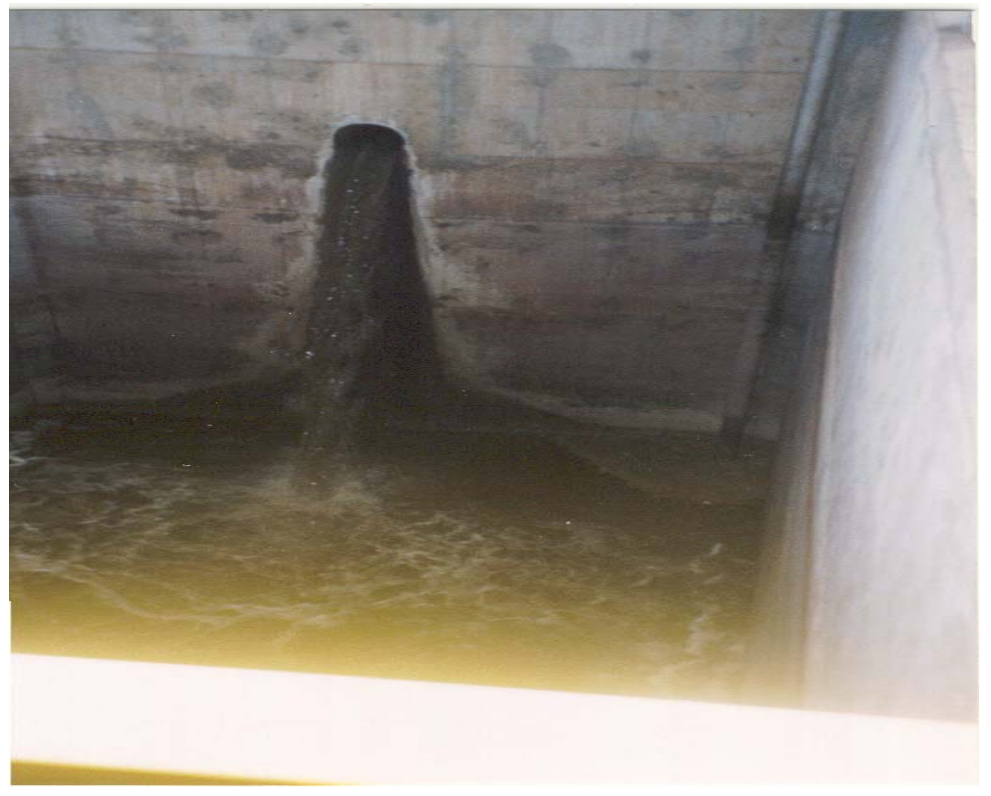

Figura 6 - Poço de grossos da ETE-Ribeirão Preto

Segundo a AMBIENT (2005), uma vez retirados os sólidos grosseiros, o esgoto segue por bombeamento para o pré-tratamento (no ponto 2 e 3 da Figura 5) que é composto das seguintes fases abaixo indicadas.

- Gradeamento intermediário e fino - remove os sólidos intermediários e finos, por uma grade automática de $3 \mathrm{~mm}$, encaminhando-os a um contêiner.

- Desarenador e desengordurador (Figura 7) - nessa fase são extraídas e separadas toda areia e gordura presentes no esgoto, através de sistema composto de uma ponte móvel/bomba vertical/separadores, sendo encaminhados a um contêiner. $\mathrm{O}$ desarenador é do tipo desengraxado aerado e é constituído de $1+1$ sopradores de 400 $\mathrm{Nm}^{3} / \mathrm{h}$ a $3,70 \mathrm{mca}$, canal longitudinal com ponte rolante, bomba de areias $50 \mathrm{~m}^{3} / \mathrm{h}$ a 1,50 mca, concentrador de gorduras, medidor de vazão eletromagnético. A ponte rolante passa pelo canal, removendo a areia e a gordura. A gordura é empurrada 
através do canal da esquerda até cair em um outro tanque onde recebe um pequeno volume de água para poder ser transportada até os tanques que a levarão para o aterro sanitário do município de Ribeirão Preto-SP. A areia sedimenta no tanque da direita, é sugada do seu fundo e transportada para outros tanques, juntamente com a gordura extraída;

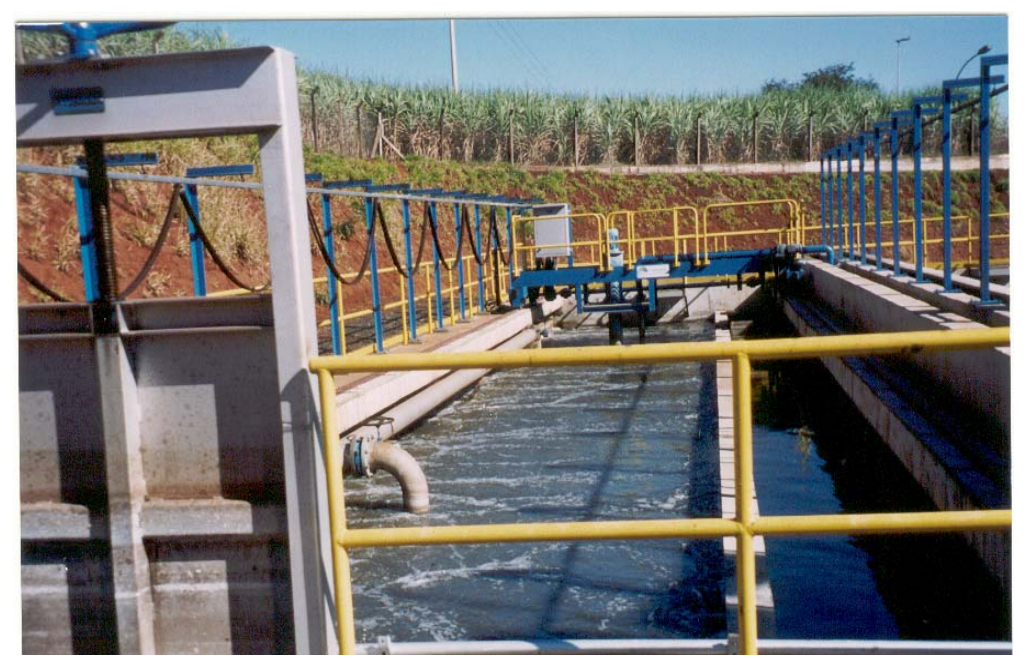

Figura 7 - Vista parcial do desarenador e desengordurador da ETERibeirão Preto

Todo resíduo retirado no pré-tratamento é transportado para disposição final no Aterro Sanitário do Município de Ribeirão Preto-SP. O esgoto, isento de sólidos, areia e gordura, segue o tratamento, em direção ao Decantador Primário (ponto 7 da Figura $5)$.

- No Decantador Primário (Figura 8) ocorre a separação de sólidos sedimentáveis e dissolvidos. Em seguida, o esgoto vai para o Reator Biológico. 


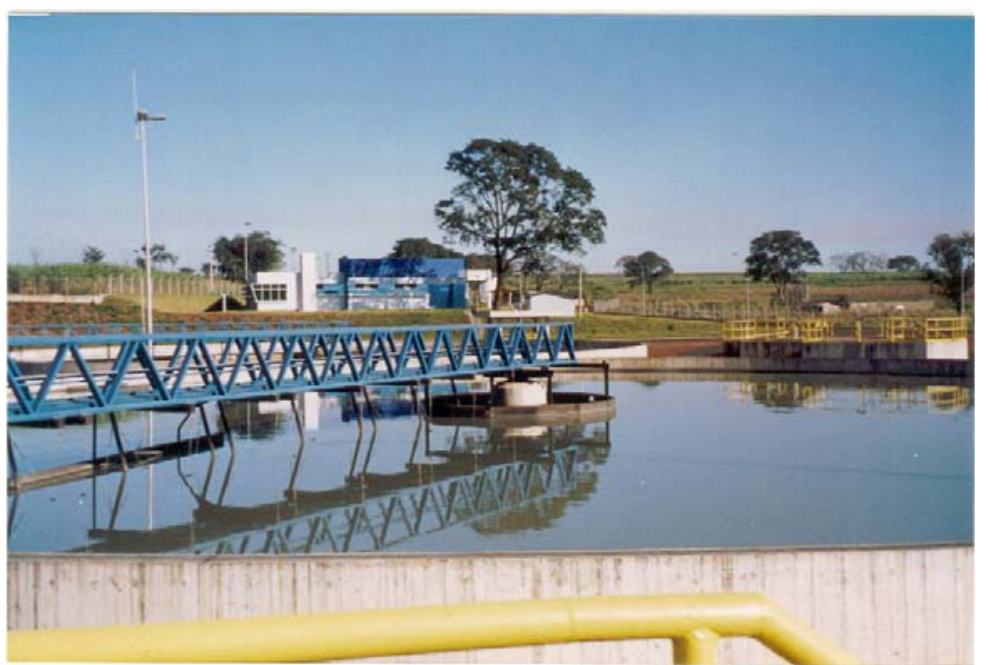

Figura 8 - Vista parcial dos decantadores primários da ETE- Ribeirão Preto

- No reator biológico (Figura 9) mostrado no (ponto 10 da Figura 5), por meio de um tratamento biológico, o esgoto é aerado para fornecer oxigênio aos microorganismos presentes, que assimilam a matéria orgânica contaminante, efetuando a limpeza do esgoto. O reator biológico é do tipo carrossel e a aeração é feita através de duas turbinas de $110 \mathrm{KW}$ e 2 agitadores submergíveis.
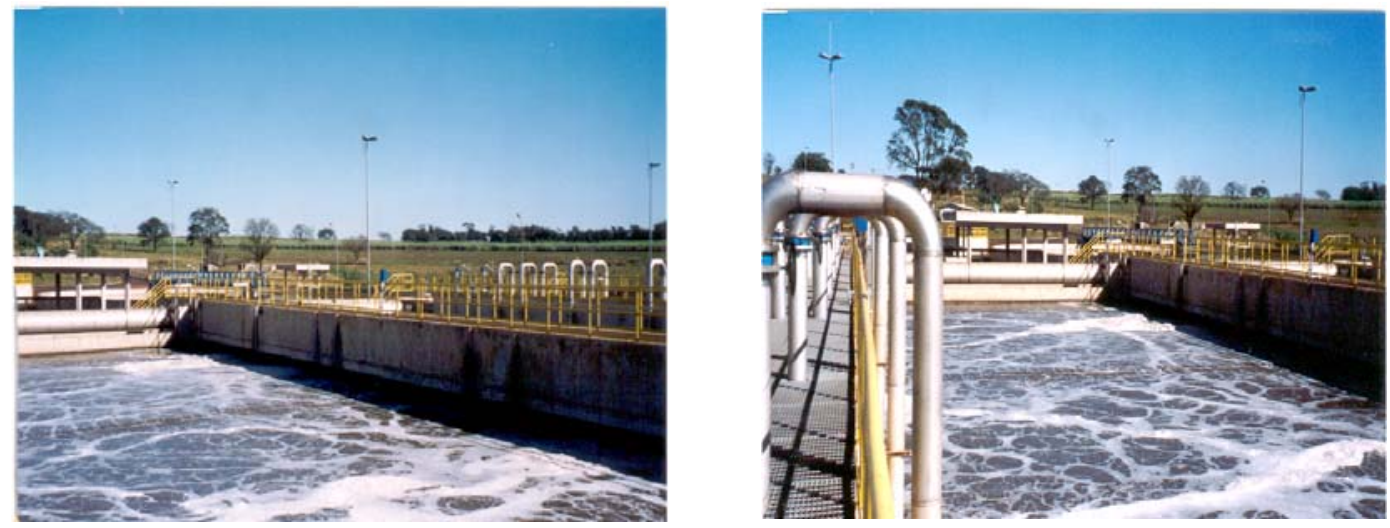

Figura 9 - Vistas parciais dos reatores biológicos 
- Saindo do reator biológico, o efluente vai para o decantador secundário (Figura 10), podendo ser visto no (ponto 12 da Figura 5), onde a parte líquida é separada do lodo restante, tanto os sólidos que sedimentam quanto aqueles que permanecem em suspensão na superfície da massa líquida são retirados, constituindo o lodo ativado, do esgoto tratado. Essa separação é realizada no decantador secundário, onde uma parcela desse lodo retorna ao reator biológico para manter o controle e o equilíbrio do processo de tratamento. A outra parcela será encaminhada aos biodigestores, juntamente com os sólidos sedimentados que foram separados no decantador primário.

- Parte dos lodos de fundo, provenientes do decantador secundário, são recirculados para o tratamento biológico. O restante é bombeado para o espessador, onde os lodos são adensados para diminuir seu volume. O espessador possui diâmetro de $12 \mathrm{~m}$ e profundidade de $4 \mathrm{~m}$.
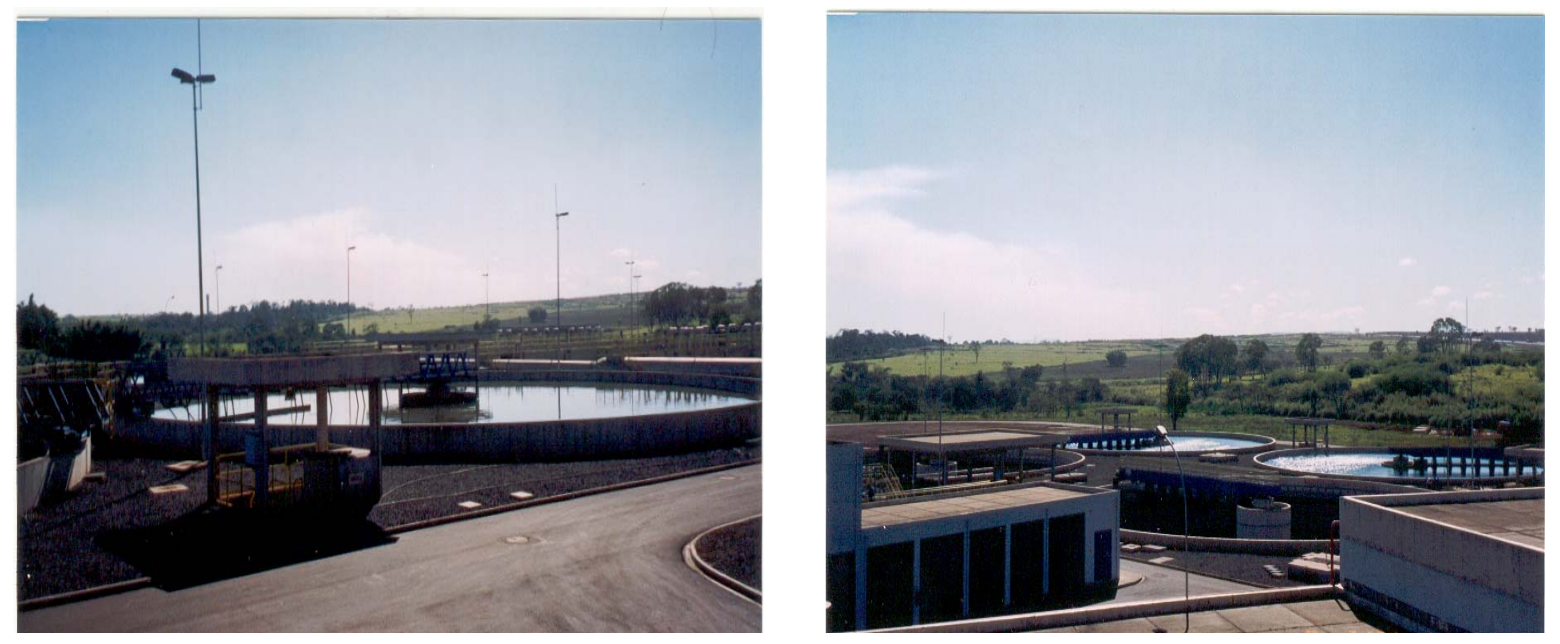

Figura 10 - Decantadores secundários da ETE-Ribeirão Preto

- Nos digestores (ponto 19 da Figura 5) é realizada a homogeneização e estabilização dos lodos através de tratamento biológico anaeróbio. Nesse processo do tratamento, o gás gerado é reutilizado como combustível de um sistema de aquecimento do próprio 
lodo. Após o tratamento, o lodo é desidratado (ponto 24 da Figura 5), dando origem a um biossólido (Figura 11), que será utilizado como adubo orgânico.

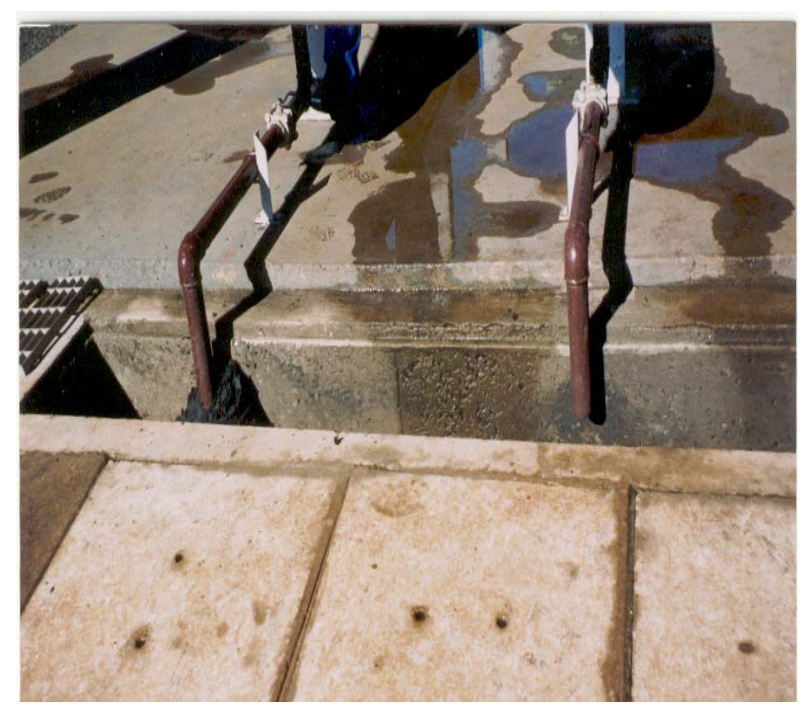

Figura 11 - Lodo desidratado da ETE-Ribeirão Preto

- O esgoto já tratado passa pela câmara de cloração (Figura 12) e (ponto 15 da Figura 5) por medida de segurança, mas só será tratado com hipoclorito de sódio se existir uma epidemia na cidade, sendo então lançado no Ribeirão Preto. O sistema utilizado para a cloração é composto por um tanque de hipoclorito de sódio (17 000 litros) e 1+1 bombas dosadoras $150 \mathrm{~L} / \mathrm{h}$ a $60 \mathrm{mca}$. 


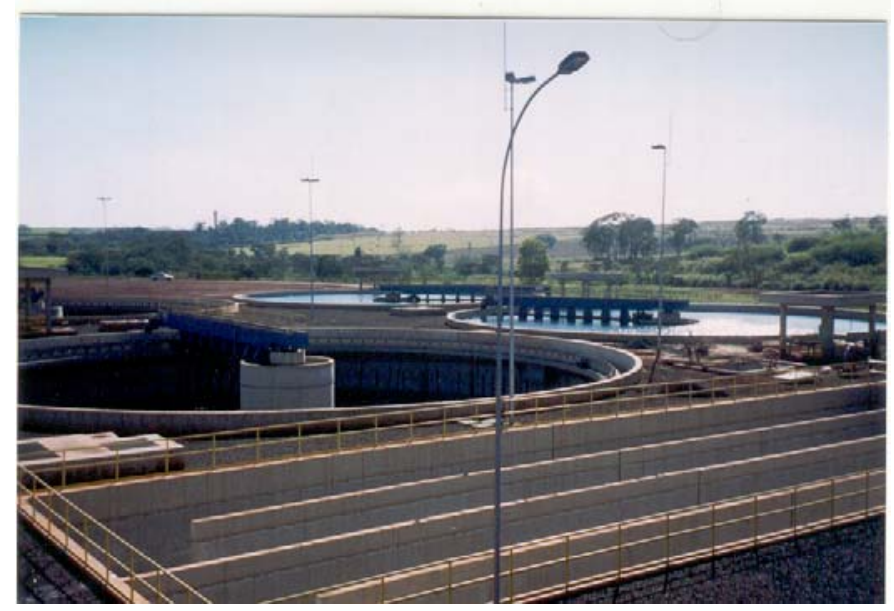

Figura 12 - Câmara de cloração da ETE-Ribeirão Preto

E por último o esgoto tratado sai pela fonte de saída (Figura 13) e (ponto 16 da

Figura 5).

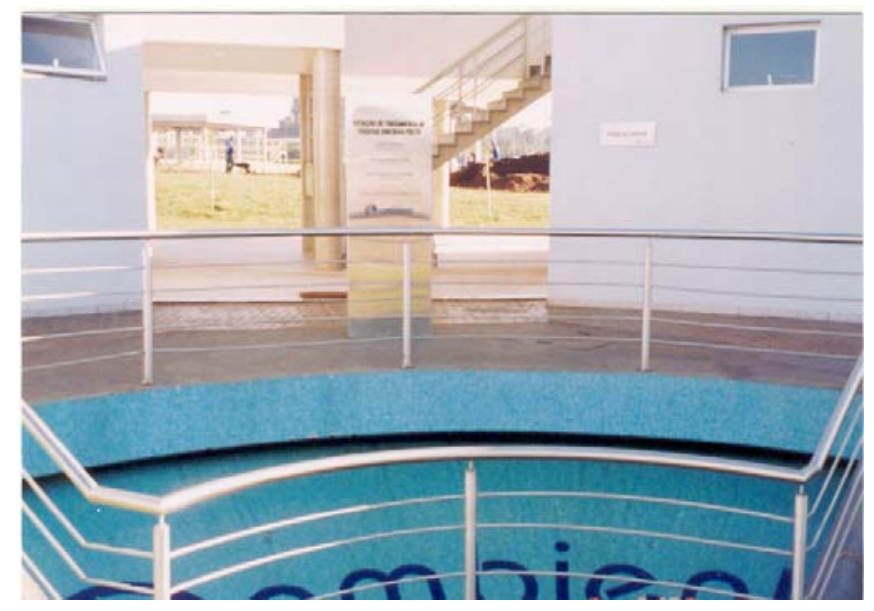

Figura 13 - Fonte de saída da ETE-Ribeirão Preto

$\mathrm{Na}$ Tabela 5, são apresentadas algumas das características de funcionamento da ETE-Ribeirão Preto. 
Tabela 5 - Algumas características de funcionamento da ETE-Ribeirão Preto, em 2005

\begin{tabular}{lc}
\hline \hline Características de Funcionamento & Capacidade \\
\hline \hline Capacidade de atendimento na 1 ${ }^{\text {a }}$ etapa & $560000 \mathrm{hab}$ \\
Vazão média & $130000 \mathrm{~m}^{3} / \mathrm{dia}$ \\
Volume de escavação e terraplanagem & $190000 \mathrm{~m}^{3}$ \\
Volume de concreto & $25000 \mathrm{~m}^{3}$ \\
Quantidade de aço & $2300000 \mathrm{~kg}$ \\
Rede de interceptores & $17000 \mathrm{~m}$ \\
\hline \hline Empregos gerados (diretos e indiretos) & 2000 \\
\hline \hline Fonte - AMBIENT, 2005.
\end{tabular}

Diante do exposto anteriormente, considera-se importante a avaliação dos níveis de metais pesados no esgoto antes e após o tratamento, assim como no lodo formado durante o tratamento, com a finalidade de compreender a capacidade de remoção de metais do sistema de tratamento de esgoto por lodos ativados, sistema adotado no Município de Ribeirão Preto para tratamento de esgotos. Assim, o presente estudo visa oferecer ferramentas que subsidiarão a tomada de decisão das autoridades encarregadas do tratamento de esgoto da Prefeitura Municipal de Ribeirão Preto. 


\section{OBJETIVOS}

\subsection{OBJETIVO GERAL}

Avaliar a capacidade de remoção de metais pesados do sistema de tratamento biológico de esgoto sanitário por lodos ativados.

\subsection{OBJETIVOS ESPECÍFICOS}

1. Avaliar os níveis de metais pesados em esgoto sanitário urbano, antes e após o seu tratamento de esgoto pelo sistema de lodos ativados, no município de Ribeirão Preto-SP.

2. Avaliar os níveis de metais pesados no lodo formado durante o tratamento de esgoto por sistema de lodos ativados, considerando sua possível utilização com fins agrícolas.

3. Apresentar as informações geradas para as autoridades públicas sanitárias, ambientais e municipais, bem como às instituições responsáveis pelo tratamento de esgotos do município de Ribeirão Preto-SP. 
3 MATERIAIS E MÉTODOS 


\section{MATERIAIS E MÉTODOS}

Trata-se de pesquisa experimental de tipo transversal, baseada em investigações que produzem "instantâneas” mensurações das variáveis de interesse da situação, observando fator e efeito no mesmo momento histórico, utilizando amostras representativas de referência precisamente delimitadas (ROUQUAYROL; ALMEIDA FILHO, 1993). Essa investigação avalia os níveis de metais pesados em esgoto bruto, tratado e no lodo, procedentes da estação de tratamento pelo sistema de lodos ativados do município de Ribeirão Preto-SP, no ano de 2004. O presente trabalho conta com o apoio e aprovação do Departamento de Água e Esgoto de Ribeirão Preto (DAERP) e, também, AMBIENT-Serviços Ambientais de Ribeirão Preto SA (ANEXO A) responsável pela estação de tratamento de esgoto no município de Ribeirão Preto.

O projeto se realizou com o apoio financeiro da Fundação de Amparo à Pesquisa do Estado de São Paulo (FAPESP), através do auxílio à pesquisa, processo no 02/11831-6 da $\operatorname{Prof}^{\mathfrak{a}} \operatorname{Dr}^{\mathrm{a}}$ Susana Inés Segura Muñoz, no Programa de Apoio a Jovem Pesquisador com o estudo intitulado: "Distribuição espacial e variação temporal de metais pesados na área de influência do aterro sanitário e antigo incinerador de resíduos sólidos de Ribeirão Preto, SP”. Assim como, da bolsa de mestrado, processo n ${ }^{0} 03 / 11589-3$ da mesma instituição.

A descrição detalhada da metodologia adotada para o trabalho é apresentada a seguir.

\subsection{Local de estudo}

O município de Ribeirão Preto apresenta certa diversificação produtiva, com estabelecimentos em praticamente todos os ramos industriais. Fazem parte do parque 
produtivo do município 1070 estabelecimentos industriais. Aproximadamente $95 \%$ das indústrias correspondem a empresas de pequeno porte. Em termos setoriais, verifica-se que os ramos que possuem maior número de estabelecimentos são indústrias do setor médico hospitalar e químico (175 estabelecimentos), a indústria de alimentos (163 estabelecimentos) e a indústria metalúrgica (159 estabelecimentos) (RIBEIRÃO PRETO. PREFEITURA MUNICIPAL. PORTAL DA CIDADE DE RIBEIRÃO PRETO. CODERP, 2005).

A localização do município, bem como a ETE-Ribeirão Preto, pode ser observada no mapa do enquadramento geográfico regional, na Figura 14 e (ANEXO B). No mapa, podese observar toda a ETE-Ribeirão Preto e sua contribuição hidrográfica para o córrego Ribeirão Preto. 

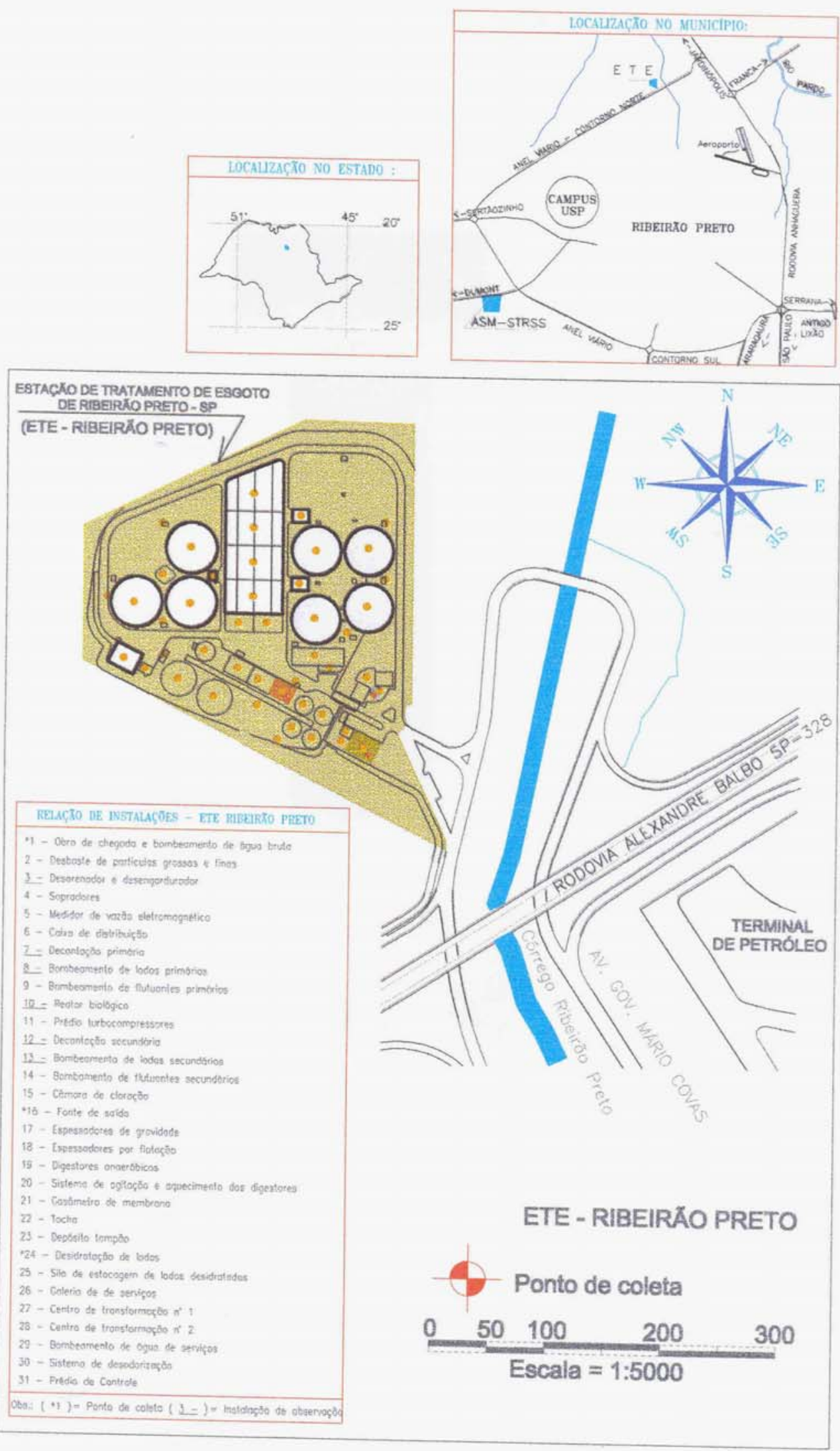

Figura 14 - Localização da ETE-Ribeirão Preto 


\subsection{Coleta de amostras}

Foram definidos como locais de coleta o poços de grossos no ponto de chegada para a amostragem do esgoto bruto, a fonte de saída para coleta de esgoto tratado e o ponto de desidratação de lodos para a amostragem de lodos.

Todos os materiais utilizados para coleta e acondicionamento das amostras foram de polietileno, previamente submergidos em solução de ácido nítrico a 30\%, por 24 horas, para eliminação de metais interferentes (VARIAN, 1988; AMERICAN PUBLIC HEALTH ASSOCIATION. APHA, 1998; VOEGBORLO; EL-METHNANI; ABEDIN, 1999) e posteriormente enxaguados com água tratada pelo sistema Milli-Q no Setor de Metais do Laboratório de Pediatria (LP) do Hospital das Clínicas da Faculdade de Medicina de Ribeirão Preto (HCFMRP)/USP.

A ETE-Ribeirão Preto forneceu o equipamento que é adaptado pela ETE para a coleta de amostras na fonte de chegada e saída, constituídos por dois baldes tipo PVC, identificados para a entrada e saída, em cuja haste é fixada uma corda.

A coleta de amostras ocorreu no intervalo do dia 28/06/2004 ao dia 06/08/2004. O total de trinta amostras foi coletado em duplicata, nesse intervalo. Cada uma dessas amostras representava uma amostra composta, produto da mistura de amostras coletadas em três momentos, com intervalos de uma hora; assim, cada dia, $50 \mathrm{ml}$ da coleta da primeira subamostra iniciava-se às 8 horas, $50 \mathrm{ml}$ da segunda subamostra era recolhida as 9 horas e, $50 \mathrm{ml}$ da terceira subamostra era coletada as 10 horas.

Todas as amostras foram preservadas com ácido nítrico concentrado até $\mathrm{pH}$ menor que 2, de acordo com CETESB (SÃO PAULO. CETESB, 1987). 
As amostras de esgoto bruto foram coletadas na Obra de Chegada e Bombeamento de água bruta, onde ocorre a chegada do esgoto por gravidade (Figura 15), em recipientes de polietileno de $250 \mathrm{ml}$.

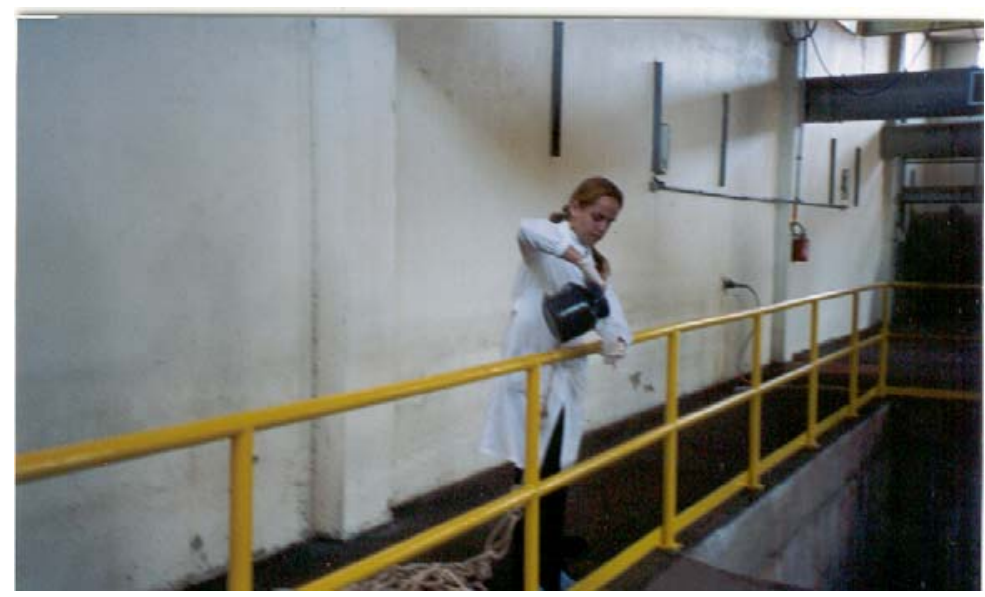

Figura 15 - Coleta de esgoto bruto no poço de grossos, na chegada da ETE-Ribeirão PretoSP, de 28/06 a 06/08 de 2004

Trinta amostras de esgoto tratado foram coletadas na fonte de saída, como é apresentado na Figura 16.
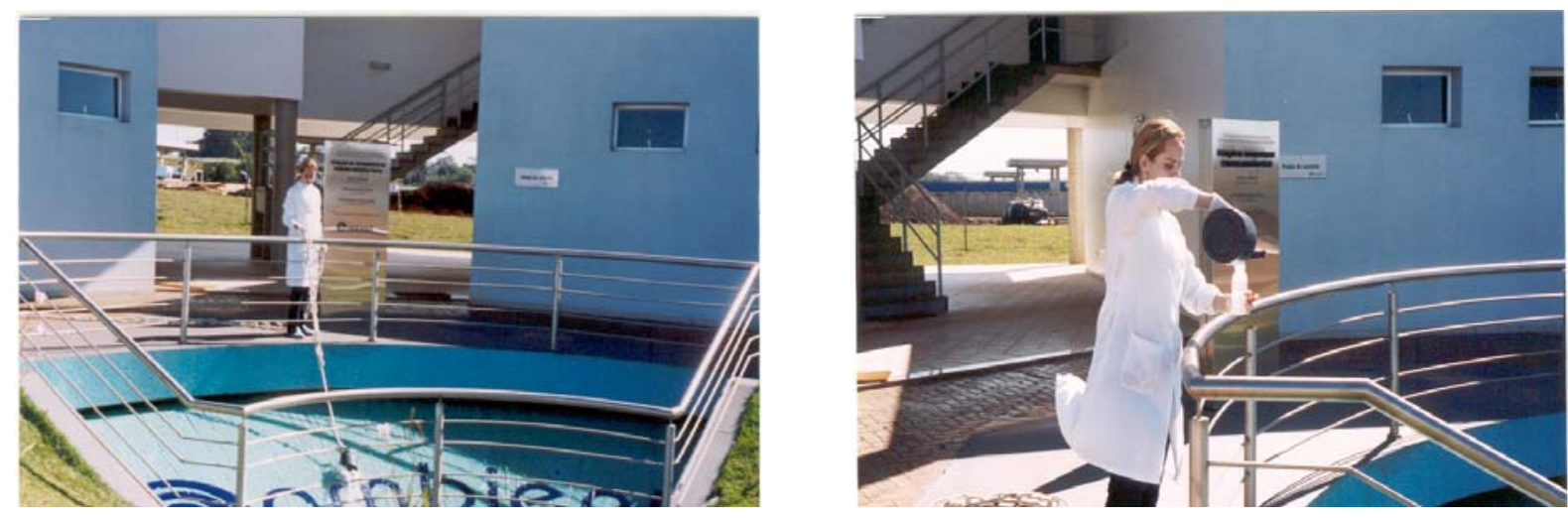

Figura 16 - Coleta de esgoto tratado, na Fonte de saída da ETE-Ribeirão Preto, de 28/06 a 06/08 de 2004 
Trinta amostras em duplicata de lodo foram coletadas após o processo de desidratação, em dias e horários alternados (Figura 17), conforme a geração desse subproduto, dependendo da vazão e do funcionamento da ETE Ribeirão.

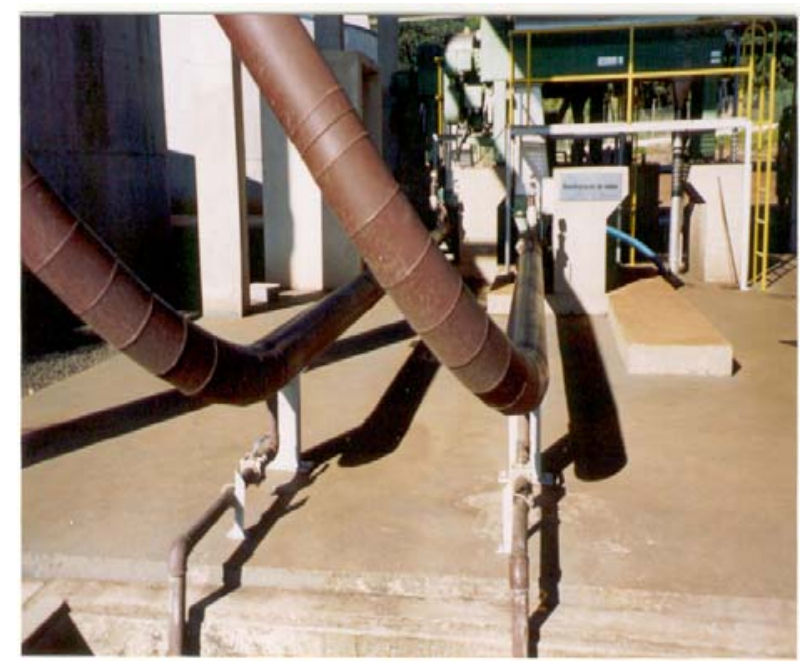

Figura 17 - Local de coleta de lodo desidratado da ETE-Ribeirão Preto-SP, de 28/06 a 06/08 de 2004

\subsection{Leitura de pH e temperatura}

As leituras dos valores de $\mathrm{pH}$ das amostras de esgoto bruto foram realizadas no laboratório de controle de qualidade da ETE-Ribeirão Preto, os resultados foram obtidos através de medidor digital marca Endress Hauser Liquisys-s, mod. CPM 253-PR 0015 de leitura direta. Para a leitura de temperatura foi utilizado medidor digital, marca Rosemount Analytical, mod.389 VP de leitura direta. 


\subsection{Preparação das amostras para dosagem de metais pesados}

Esgoto bruto e esgoto tratado - foi adicionado ácido nítrico de alta pureza (65\% Suprapur-Merk, Germany) às amostras, para fixação dos metais, a um $\mathrm{pH}<2,00$. As amostras foram mantidas a $-18^{\circ} \mathrm{C}$ até o momento da análise. Posteriormente, as amostras foram centrifugadas por 3 minutos, retirado o sobrenadante, e, em seguida, as amostras foram levadas para leitura de metais (APHA, 1998).

Lodo - as amostras de lodo foram mantidas a $-18^{\circ} \mathrm{C}$ no freezer do laboratório em recipientes de polietileno e protegidas para evitar contaminação por agentes externos. Para a preparação das amostras de lodo, foram pesados $10 \mathrm{~g}$ de lodo e adicionados $50 \mathrm{ml}$ de água tratada pelo sistema Milli-Q, e homogeneizadas manualmente. A seguir, as soluções foram liofilizadas em liofilizador da marca Labconco Freeze Dryer modelo 5, em equipamento do Laboratório de Nutrição da Faculdade de Medicina de Ribeirão Preto da Universidade de São Paulo.

As amostras liofilizadas foram encaminhadas para o Laboratório de Toxicologia e Saúde Meio Ambiental da Universidade Rovira e Virgili, Réus, Tarragona, na Espanha. Para a digestão do lodo, foram pesados $0,500 \mathrm{~g}$ de cada amostra em bombas herméticas de teflon de 200ml, adicionados $5 \mathrm{ml}$ de $\mathrm{HNO}_{3}(65 \%$ v/v, Suprapur - Merk, Germany). Foi realizada prédigestão por 8 horas à temperatura ambiente em repouso. Passado esse tempo (Figura 18), as amostras foram digeridas em temperatura de $80^{\circ} \mathrm{C}$, durante 8 horas. Após o término da digestão e resfriamento das amostras, foi filtrado e transferido quantitativamente para balões de $25 \mathrm{ml}$, completando-se o volume com água tratada pelo sistema Milli-Q (SEGURAMUÑOZ et al., 2004, 2006). 


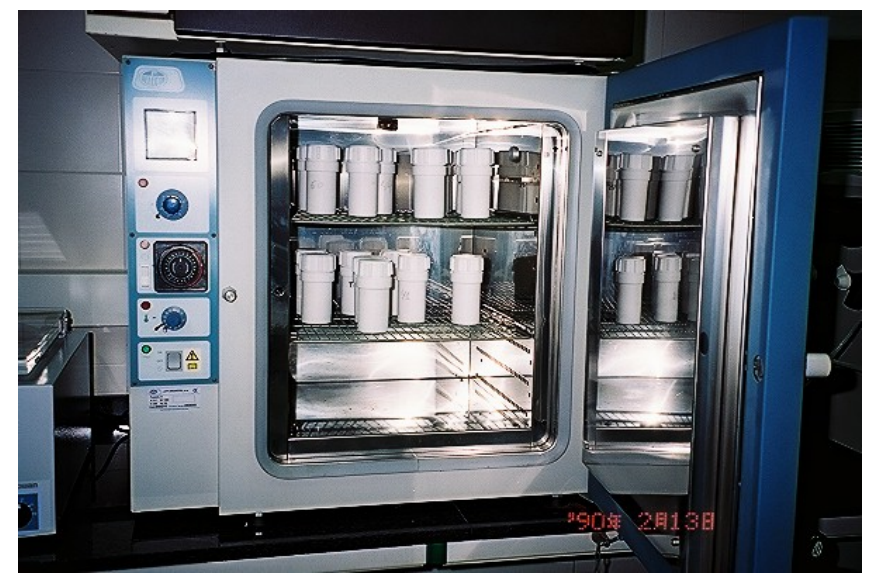

Figura 18 - Digestão das amostras de lodo em ácido nítrico a 65\%, em bombas de teflon, por 16 horas.

(Fonte - Segura-Muñoz, 2005).

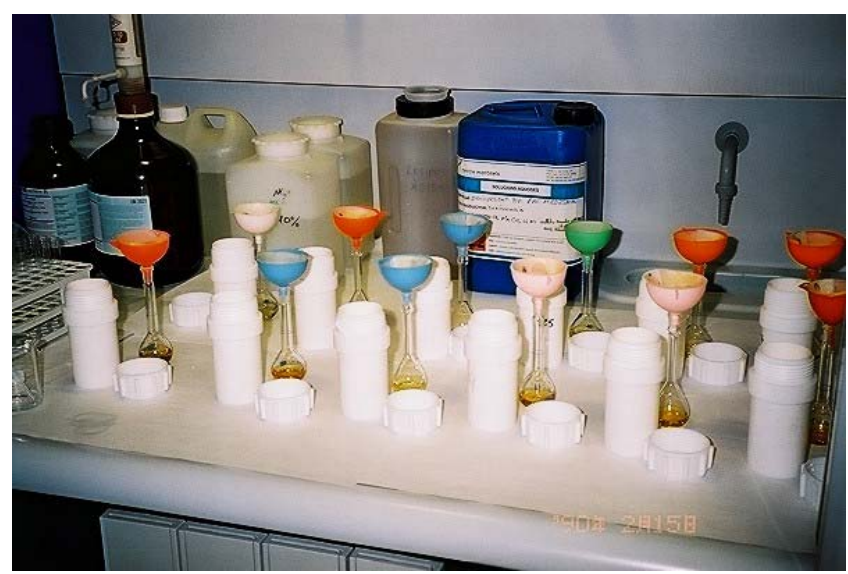

Figura 19 - Filtração e diluição das amostras uma vez digeridas, preparação das amostras para leitura de metais pesados

(Fonte - Segura-Muñoz, 2005).

\subsection{Dosagens de metais no esgoto bruto e tratado}

As dosagens de cromo, chumbo, cádmio, manganês e cobre foram realizadas por

Espectrofotometria de Absorção Atômica com Forno de Grafite (AAE-FG) num espectrofotômetro VARIAN-ZEEMAN, modelo 640-Z. A dosagem de Hg foi realizada por 
espectrofotometria de Absorção Atômica com Geração de Hidreto (AAS-HG) num espectrofotômetro VARIAN, modelo AA-200. E as dosagens de $\mathrm{Cu}$ e $\mathrm{Zn}$ foram realizadas por Espectrofotometria de Absorção Atômica de Chama (FAAS-Chama) num espectrofotômetro VARIAN, modelo AA-200 (Figura 20). Os limites de detecção das técnicas utilizadas para análise dos metais pesados no esgoto bruto e no esgoto tratado são de $0,1 \mathrm{ug} / \mathrm{L}$ para $\mathrm{Cr}, \mathrm{Pb}$, Mn e Zn; 0,01 ug/L para Cd e $\mathrm{Hg}$ e 0,5 ug/L para $\mathrm{Cu}$.

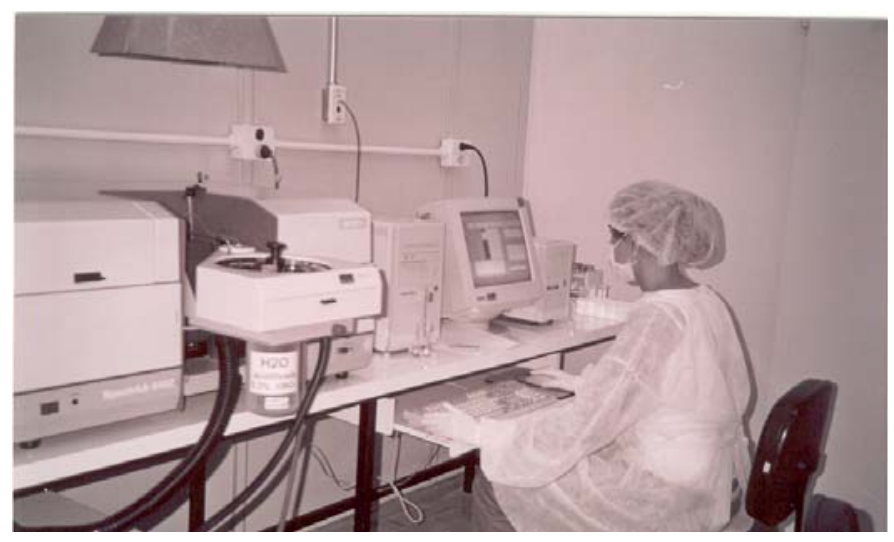

Figura 20 - Espectrofotômetro de Absorção Atômica com Forno de Grafite (EAA-FG) e com Gerador de Hidretos e Chama (EAA-VGA/ EAA-Chama), setor de metais do laboratório de pediatria do Hospital das Clínicas da FMRP/USP

\subsection{Dosagens de metais no lodo (ICP)}

A concentração de $\mathrm{As}, \mathrm{Be}, \mathrm{Cd}, \mathrm{Hg}, \mathrm{Mn}, \mathrm{Pb}, \mathrm{St}$, TI e V foram determinadas por Espectroscopia com Plasma Induzido-Espectroscopia de Massas (ICP-MS, Perkin Elmer Elan 6000), e a concentração de $\mathrm{Cr}, \mathrm{Cu}, \mathrm{Fe}$ e $\mathrm{Zn}$ por Espectroscopia com Plasma InduzidoEspectroscopia Óptico (ICP-OES); os níveis de Ni foram analisados por Espectrofometria de Absorção Atômica, acoplado a Forno de Grafite (AAS-FG, UNICAM 939/959) (SCHUHMACHER et al., 2002; SEGURA-MUÑOZ, 2004), no Laboratório de Toxicologia e 
Saúde Meio Ambiental da Universidade Rovira e Virgili, Réus, Tarragona, na Espanha. Os limites de detecção das técnicas utilizadas para análise dos metais pesados no lodo são de 0,02 $\mathrm{mg} / \mathrm{kg}$ para Ni; 0,03 mg/kg para $\mathrm{Cd}, \mathrm{Mn}, \mathrm{Pb}$ e Tl; 0,05 mg/kg para $\mathrm{Cu}, \mathrm{Fe}, \mathrm{Hg}, \mathrm{Sn}$ e Zn; 0,1 $\mathrm{mg} / \mathrm{kg}$ para As; e $0,25 \mathrm{mg} / \mathrm{kg}$ para $\mathrm{Be}, \mathrm{Cr}$ e V.

\subsection{Curva analítica}

A partir de uma solução estoque de cada metal, cuja concentração exata é de 1 000 mg/L, foi preparada uma solução-padrão para cada metal em concentrações específicas. A solução padrão permitiu o traçado automático da curva de calibração para cada metal, dentro das diferentes faixas de linearidade.

\subsection{Validação dos métodos}

Foram utilizados padrões certificantes do Instituto Quality Control Technologies Pty Ltd., Queensland, Austrália, para as amostras de esgoto bruto e tratado NW360, NW 367, NW 384 e NW 388. Para as amostras de lodo foram utilizadas como certificantes, S121 e S-129.

Com o objetivo de validar o método, utilizou-se um certificante S-129 do Instituto Quality Control Technologies Pty Ltd., Queensland, Austrália, para as amostras de lodo (Tabela 6), verificando a exatidão do método utilizado para alguns dos metais analisados.

Os resultados foram considerados de boa qualidade quando os padrões apresentaram uma margem de erro sistemático de até $20 \%$. O cálculo do erro sistemático (\%BIAS) foi realizado através da seguinte expressão, segundo Causon (1997): 
$\%$ BIAS $=[($ valor estimado - valor real $) /$ valor real $] \times 100$

A Tabela 6 apresenta os valores obtidos no Laboratório de Toxicologia e Saúde Meio Ambiental da Universidade Rovira e Virgili, Réus, Tarragona, Espanha, com a amostra certificante S-129 para as dosagens do lodo. E pode se observar que os metais $\mathrm{Mn}, \mathrm{Cr}, \mathrm{Zn}$, $\mathrm{Cu}, \mathrm{Cd}$ e $\mathrm{Pb}$ encontram-se dentro dos valores certificantes do Instituto Quality Control Technologies Pty Ltd., Queensland, Austrália.

Tabela 6 - Concentração de $\mathrm{Mn}, \mathrm{Cr}, \mathrm{Zn}, \mathrm{Cu}, \mathrm{Cd}, \mathrm{Pb}$ na amostra certificante S-129 com seus respectivos valores esperados em $\mathrm{mg} / \mathrm{Kg}$

\begin{tabular}{ccc}
\hline \hline Elemento & $\begin{array}{c}\text { Valores esperados do } \\
\text { certificante S-129 }\end{array}$ & $\begin{array}{c}\text { Valores obtidos no } \\
\text { Laboratório }\end{array}$ \\
\hline \hline$* \mathrm{Mn}$ & $31,7 \pm 4,1$ & 33,78 \\
$* * \mathrm{Cr}$ & $27,7 \pm 11,3$ & 36,55 \\
$* * \mathrm{Zn}$ & $22,9 \pm 4,3$ & 17,40 \\
$* * \mathrm{Cu}$ & $1,8 \pm 1,9$ & $<0,010$ \\
$* \mathrm{Cd}$ & 0 & 0,01 \\
$* \mathrm{~Pb}$ & $7,5 \pm 5,4$ & 6,13 \\
\hline \hline
\end{tabular}

\subsection{Análise dos resultados}

Para as análises dos níveis de metais no esgoto foram considerados os valores máximos permitidos no Decreto Estadual n8468/76 (Tabela 7), que dispõe sobre a prevenção e o controle da poluição de meio ambiente (SÃO PAULO, Decretos, 1976), e atualmente, a Resolução $\mathrm{N}^{0} .357$ de 17 de março de 2005 que dispõe sobre a classificação dos corpos de água e diretrizes ambientais para o seu enquadramento, bem como estabelece as condições e padrões de lançamento de efluentes (BRASIL. CONSELHO NACIONAL DO MEIO AMBIENTE. CONAMA, 2005).

Para a realização dos testes estatísticos foi utilizado o Programa Estatístico GraphPad 
Prism (Version 3.02 for Windows, GraphPad Software, San Diego, CA, USA), através do teste estatístico não-paramétrico Mann-Whitney. O nível de significância utilizado foi de $\alpha=$ 0,05 (ZAR, 1999).

Tabela 7 - Limitações de descarga para estações de tratamento de esgoto, estabelecidas pelo artigo 18 e 21 do CONAMA 20/86 e 357/05, para os traços metálicos

\begin{tabular}{|c|c|c|c|}
\hline Parâmetro & Unidades & $\begin{array}{l}\text { DEC. } \\
8468 / 76\end{array}$ & $\begin{array}{l}\text { CONAMA } 20 / 86 \\
\text { CONAMA357/05 }\end{array}$ \\
\hline Arsênio & $\mathrm{mg} / 1$ & 0,2 & 0,5 \\
\hline Bário & $\mathrm{mg} / \mathrm{l}$ & 5,0 & 5,0 \\
\hline Boro & $\mathrm{mg} / \mathrm{l}$ & 5,0 & 5,0 \\
\hline Cádmio & $\mathrm{mg} / \mathrm{l}$ & 0,2 & 0,2 \\
\hline Chumbo & $\mathrm{mg} / 1$ & 0,5 & 0,5 \\
\hline Cobre & $\mathrm{mg} / \mathrm{l}$ & 1,0 & 1,0 \\
\hline Cromo Hexavalente & $\mathrm{mg} / \mathrm{l}$ & 0,1 & 0,5 \\
\hline Cromo Total & $\mathrm{mg} / \mathrm{l}$ & 5,0 & -- \\
\hline Cromo Trivalente & $\mathrm{mg} / \mathrm{l}$ & --- & 2,0 \\
\hline Estanho & $\mathrm{mg} / \mathrm{l}$ & 4,0 & 4,0 \\
\hline Ferro Solúvel & $\mathrm{mg} / \mathrm{l}$ & 15,0 & 15,0 \\
\hline Manganês Solúvel & $\mathrm{mg} / \mathrm{l}$ & 1,0 & 1,0 \\
\hline Mercúrio & $\mathrm{mg} / \mathrm{l}$ & 0,01 & 0,01 \\
\hline Níquel & $\mathrm{mg} / \mathrm{l}$ & 2,0 & 2,0 \\
\hline Prata & $\mathrm{mg} / 1$ & 0,02 & 0,1 \\
\hline Selênio & $\mathrm{mg} / \mathrm{l}$ & 0,02 & 0,05 \\
\hline Zinco & $\mathrm{mg} / \mathrm{l}$ & 5,0 & 5,0 \\
\hline Temperatura & ${ }^{\circ} \mathrm{C}$ & $<40$ & $<40$ \\
\hline $\mathrm{pH}$ & & $\begin{array}{l}\text { Entre } 5,0 \\
9,0\end{array}$ & e Entre 5,0 e 9,0 \\
\hline
\end{tabular}




\section{RESULTADOS E DISCUSSÃO}

Esta investigação avaliou os níveis de metais no esgoto antes e depois do tratamento biológico por lodos ativados, assim como no lodo formado durante o tratamento de esgoto na ETE-RP no município de Ribeirão Preto.

No presente estudo foram quantificados os níveis de $\mathrm{Cu}, \mathrm{Cd}, \mathrm{Cr}, \mathrm{Hg}, \mathrm{Mn}, \mathrm{Pb}$ e Zn para o esgoto tratado e não tratado. Enquanto que, para o lodo, foram quantificados os níveis de $\mathrm{As}, \mathrm{Be}, \mathrm{Cd}, \mathrm{Cr}, \mathrm{Cu}, \mathrm{Fe}, \mathrm{Hg}, \mathrm{Mn}, \mathrm{Pb}, \mathrm{St}, \mathrm{TI}, \mathrm{V}$ e $\mathrm{Zn}$.

\subsection{Esgoto bruto e tratado}

Sabe-se que a concentração de metais nos efluentes de esgoto varia enormemente. Concentrações elevadas de diferentes metais podem representar um potencial risco ao meio ambiente e à saúde pública, como resultado de sua acumulação no meio ambiente (US. ASTDR, 1997; WHO, 1998).

Os resultados obtidos das análises de metais nas amostras de esgoto bruto e esgoto tratado coletadas na ETE-Ribeirão Preto, com seu respectivo valor médio, desvio padrão, valor mínimo e máximo, são apresentados nas Tabelas 8 e 9. 
Tabela 8 - Concentração média de metais em amostras de esgoto, coletadas no momento da entrada do efluente bruto na ETE-Ribeirão Preto, SP, em 2004

\begin{tabular}{|c|c|c|c|c|c|c|c|}
\hline \multirow{2}{*}{$\begin{array}{c}\text { Data da } \\
\text { Coleta }\end{array}$} & \multicolumn{7}{|c|}{ Concentração expressa em ug/L } \\
\hline & Cd* & Cr* & $\mathbf{C u}^{*}$ & Mn* & $\mathbf{H g}^{* * *}$ & Pb* & $\mathrm{Zn} * *$ \\
\hline $28 / 06$ & 0,20 & 6,25 & 27,13 & 257,31 & 0,13 & 25,30 & 105,50 \\
\hline $29 / 06$ & 0,21 & 2,11 & 18,91 & 49,79 & 0,18 & 13,06 & 58,30 \\
\hline $30 / 06$ & 0,10 & 2,97 & 16,51 & 48,64 & 0,16 & 17,90 & 51,10 \\
\hline $01 / 07$ & 0,15 & 6,96 & 19,03 & 53,24 & 0,05 & 13,68 & 60,25 \\
\hline $02 / 07$ & 0,09 & 3,28 & 15,32 & 54,94 & 0,13 & 17,36 & 44,95 \\
\hline 03/07 & 0,06 & 6,50 & 15,56 & 61,79 & 0,08 & 23,56 & 36,80 \\
\hline $05 / 07$ & 0,08 & 3,05 & 19,53 & 55,21 & 0,09 & 20,34 & 52,10 \\
\hline $06 / 07$ & 0,07 & 4,67 & 14,35 & 48,12 & 0,06 & 18,81 & 49,15 \\
\hline $07 / 07$ & 0,08 & 8,97 & 17,76 & 49,96 & 0,10 & 69,64 & 49,85 \\
\hline $08 / 07$ & 0,15 & 7,23 & 18,91 & 52,86 & 0,17 & 31,06 & 134,50 \\
\hline $13 / 07$ & 1,19 & 6,09 & 28,50 & 59,92 & 0,19 & 17,63 & 236,50 \\
\hline $14 / 07$ & 0,07 & 7,39 & 17,97 & 49,92 & 0,18 & 28,02 & 59,20 \\
\hline $15 / 07$ & 0,09 & 5,50 & 20,73 & 53,32 & 0,16 & 22,72 & 61,00 \\
\hline $16 / 07$ & 0,12 & 8,44 & 22,75 & 49,56 & 0,50 & 9,66 & 70,50 \\
\hline $17 / 07$ & 0,08 & 20,73 & 16,49 & 48,36 & 0,12 & 25,03 & 44,15 \\
\hline $19 / 07$ & 0,07 & 13,95 & 24,93 & 56,95 & 0,28 & 57,88 & 60,40 \\
\hline $20 / 07$ & 0,12 & 6,19 & 13,17 & 50,39 & 0,18 & 37,20 & 39,55 \\
\hline $21 / 07$ & 0,13 & 8,31 & 12,41 & 47,91 & 0,14 & 86,63 & 62,30 \\
\hline $22 / 07$ & 0,07 & 7,41 & 20,71 & 49,98 & 0,13 & 334,00 & 99,40 \\
\hline $23 / 07$ & 0,07 & 8,84 & 13,49 & 49,01 & 0,10 & 20,71 & 79,65 \\
\hline $26 / 07$ & 0,06 & 4,88 & 11,10 & 47,83 & 0,12 & 25,54 & 71,90 \\
\hline $27 / 07$ & 0,17 & 11,22 & 13,83 & 54,83 & 0,03 & 36,68 & 111,00 \\
\hline $28 / 07$ & 0,06 & 3,35 & 10,66 & 50,44 & 0,02 & 18,87 & 90,75 \\
\hline $29 / 07$ & 0,11 & 3,97 & 13,49 & 53,42 & 0,07 & 21,25 & 87,85 \\
\hline $30 / 07$ & 0,12 & 5,85 & 11,44 & 48,60 & 0,07 & 19,00 & 72,40 \\
\hline $02 / 08$ & 0,31 & 4,78 & 17,19 & 44,26 & 0,49 & 22,80 & 103,00 \\
\hline 03/08 & 0,09 & 3,53 & 12,92 & 48,88 & 0,15 & 14,11 & 68,25 \\
\hline $04 / 08$ & 0,07 & 5,63 & 12,11 & 55,64 & 0,09 & 9,67 & 102,50 \\
\hline $05 / 08$ & 0,11 & 8,53 & 16,68 & 57,88 & 0,12 & 13,19 & 87,40 \\
\hline $06 / 08$ & 0,43 & 7,39 & 25,64 & 58,63 & 0,00 & 36,66 & 149,50 \\
\hline Média & 0,15 & 6,87 & $\begin{array}{c}17,31 \\
\end{array}$ & 252,53 & $0,0,13$ & 37,42 & $\begin{array}{c}79,20 \\
\end{array}$ \\
\hline DP & 0,21 & 3,73 & 4,93 & 4,06 & 0,09 & 59,67 & 41,06 \\
\hline Mínimo & 0,06 & 2,11 & 10,66 & 47,83 & 0,00 & 9,66 & 36,80 \\
\hline Máximo & 1,19 & 20,73 & 28,50 & 61,79 & 0,50 & 334,00 & 236,50 \\
\hline $\begin{array}{l}\text { † Valor Máximo } \\
\text { para efluentes }\end{array}$ & 200 & 500 & 1000 & 1000 & 10 & 500 & 5000 \\
\hline
\end{tabular}

Amostras determinadas por EAA-FG*, EAA-Chama **, EAA-HG***.

${ }^{\dagger}$ Resolução CONAMA 357/05 (BRASIL. CONAMA, 2005). 
Tabela 9 - Concentração média de metais nas amostras de esgoto coletadas no local da saída do esgoto tratado da ETE-Ribeirão Preto, SP, em 2004

\begin{tabular}{|c|c|c|c|c|c|c|c|}
\hline Data da & & & oncentra & $\bar{c}$ expre & em ug/l & & \\
\hline & Cd* & Cr* & Cu* & "Mn* & "Hg*** & 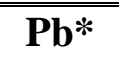 & $\overline{\mathrm{Zn} \text { Z** }}$ \\
\hline $28 / 06$ & 0,11 & 2,16 & 9,38 & 45,82 & 0,16 & 4,97 & 63,70 \\
\hline $29 / 06$ & 0,05 & 3,34 & 8,15 & 46,41 & 0,00 & 15,17 & 37,75 \\
\hline $30 / 06$ & 0,05 & 3,03 & 13,98 & 49,74 & 0,15 & 4,98 & 40,05 \\
\hline $01 / 07$ & 0,07 & 5,43 & 18,24 & 54,98 & 0,24 & 8,26 & 49,75 \\
\hline $02 / 07$ & 0,06 & 4,86 & 18,42 & 44,90 & 0,00 & 6,46 & 40,30 \\
\hline 03/07 & 0,06 & 4,42 & 13,78 & 58,39 & 0,00 & 5,51 & 34,75 \\
\hline $05 / 07$ & 0,05 & 1,68 & 6,88 & 44,29 & 0,00 & 4,22 & 28,70 \\
\hline $06 / 07$ & 0,05 & 3,62 & 8,55 & 63,35 & 0,00 & 6,29 & 38,80 \\
\hline 07/07 & 0,07 & 11,42 & 10,76 & 73,41 & 0,00 & 36,39 & 40,40 \\
\hline 08/07 & 0,06 & 11,28 & 7,86 & 52,42 & 0,00 & 43,35 & 28,45 \\
\hline $13 / 07$ & 0,05 & 5,78 & 19,07 & 50,66 & 0,00 & 50,14 & 26,95 \\
\hline $14 / 07$ & 0,08 & 8,67 & 19,78 & 43,98 & 0,00 & 55,78 & 33,20 \\
\hline $15 / 07$ & 0,05 & 5,55 & 7,58 & 48,27 & 0,00 & 27,68 & 22,80 \\
\hline $16 / 07$ & 0,04 & 5,85 & 6,69 & 47,63 & 0,00 & 11,87 & 27,05 \\
\hline $17 / 07$ & 0,05 & 13,53 & 7,20 & 42,65 & 0,00 & 64,99 & 30,85 \\
\hline $19 / 07$ & 0,05 & 9,95 & 11,83 & 35,55 & 0,00 & 76,42 & 43,50 \\
\hline $20 / 07$ & 0,05 & 6,90 & 15,11 & 42,11 & 0,00 & 58,84 & 30,70 \\
\hline $21 / 07$ & 0,05 & 6,26 & 8,35 & 38,61 & 0,00 & 33,26 & 64,60 \\
\hline $22 / 07$ & 0,06 & 6,65 & 8,26 & 54,34 & 0,00 & 11,39 & 57,45 \\
\hline $23 / 07$ & 0,05 & 4,28 & 5,78 & 50,18 & 0,00 & 10,87 & 76,25 \\
\hline $26 / 07$ & 0,04 & 2,53 & 4,30 & 46,14 & 0,11 & 16,46 & 39,00 \\
\hline $27 / 07$ & 0,09 & 4,90 & 6,01 & 42,36 & 0,08 & 12,76 & 64,05 \\
\hline $28 / 07$ & 0,05 & 5,03 & 6,53 & 38,97 & 0,03 & 17,38 & 49,90 \\
\hline $29 / 07$ & 0,06 & 5,77 & 11,31 & 42,72 & 0,07 & 17,37 & 50,40 \\
\hline $30 / 07$ & 0,04 & 5,88 & 10,95 & 45,88 & 0,12 & 14,00 & 48,30 \\
\hline $03 / 08$ & 0,06 & 5,22 & 3,77 & 40,35 & 0,10 & 7,19 & 40,75 \\
\hline $04 / 08$ & 0,04 & 4,37 & 2,13 & 36,76 & 0,15 & 9,64 & 59,85 \\
\hline $05 / 08$ & 0,04 & 3,77 & 5,03 & 41,64 & 0,04 & 16,85 & 49,45 \\
\hline $06 / 08$ & 0,05 & 4,37 & 4,42 & 41,65 & 0,07 & 5,93 & 47,85 \\
\hline Média & 0,06 & 5,74 & 9,66 & 477,04 & 0,05 & 22,57 & 43,64 \\
\hline DP & 0,02 & 2,83 & 4,86 & 8,14 & 0,07 & 20,72 & 13,44 \\
\hline Mínimo & 0,04 & 1,68 & 2,13 & 35,55 & 0,00 & 4,22 & 22,80 \\
\hline Máximo & 0,11 & 13,53 & 19,87 & 73,41 & 0,24 & 76,42 & 76,25 \\
\hline $\begin{array}{l}\text { 'Resolução } \\
\text { CONAMA }\end{array}$ & 200 & 500 & 1000 & 1000 & 10 & 500 & 5000 \\
\hline
\end{tabular}

Vale destacar que a amostra correspondente ao dia 02 de agosto, do ponto de saída do esgoto tratado da ETE-Ribeirão Preto, não consta na Tabela 9, considerando que os resultados obtidos para essa amostra apresentaram valores bem mais altos, incompatíveis, em 
relação com as demais amostras coletadas, apresentando as seguintes concentrações: Cd 0,48 ug/L; Cr 42,830 ug/L; Cu 5,17 ug/L; Mn 48,90 ug/L; Hg 0,17 ug/L; Pb 15,84 ug/L e Zn 2020 ug/L. Considera-se que esses valores foram afetados por algum material interferente ou contaminante presente especificamente nesse dia, na amostra coletada ou presente no material de coleta.

Em termos gerais, a magnitude das concentrações é significativamente maior nos esgotos não tratados do que nos esgotos tratados. Comparando os níveis de metais na entrada e saída do esgoto para $\mathrm{Cd}, \mathrm{Cu}, \mathrm{Hg}, \mathrm{Mn}, \mathrm{Pb}$ e $\mathrm{Zn}$ foram encontradas diferenças estatisticamente significantes $(\mathrm{p}<0,005)$. Os níveis de $\mathrm{Cr}$, apesar de estarem diminuídos na saída, não apresentaram diferenças estatisticamente significantes ( $p>0,005)$, quando comparados com os valores detectados na entrada. A ordem crescente dos níveis de metais da saída do esgoto é: $\mathrm{Hg}<\mathrm{Cd}<\mathrm{Cr}<\mathrm{Cu}<\mathrm{Pb}<\mathrm{Zn}<\mathrm{Mn}$.

Considerando-se a possível utilização do esgoto tratado para irrigação na agricultura, destaca-se que os níveis de todos os metais da saída da ETE-RP estão dentro dos limites permissíveis propostos para irrigação na agricultura (SÃO PAULO. CETESB, 2001).

Na Tabela 10 são apresentadas algumas recomendações internacionais de valores máximos permitidos no esgoto tratado, para $\mathrm{Cd}, \mathrm{Cr}, \mathrm{Cu}, \mathrm{Hg}, \mathrm{Mn}, \mathrm{Pb}$ e $\mathrm{Zn}$, valendo destacar que não foram encontradas outras legislações para comparação com a legislação brasileira. Pode ser observado que as recomendações para o esgoto tratado na Polônia e na Índia são bem mais rígidas que a Resolução CONAMA n ${ }^{0} 357 / 05$ do Brasil. Comparando os resultados dos níveis máximos obtidos dos metais analisados na pesquisa $(\mathrm{Cd} 0,11 \mathrm{ug} / \mathrm{L} ; \mathrm{Cr} 13,53 ; \mathrm{Cu}$ 19,87; Hg 0,24; Mn 73,41 ug/L; Pb 76,42 ug/L; Zn 76,25ug/L), verifica-se que todos estão dentro das recomendações permitidas para o esgoto tratado das referidas legislações. 
Tabela 10 -Recomendações internacionais de valores máximos permitidos de metais pesados no esgoto tratado para descarga nos rios e solos (ug/L), em diferentes países, segundo a fonte de informação

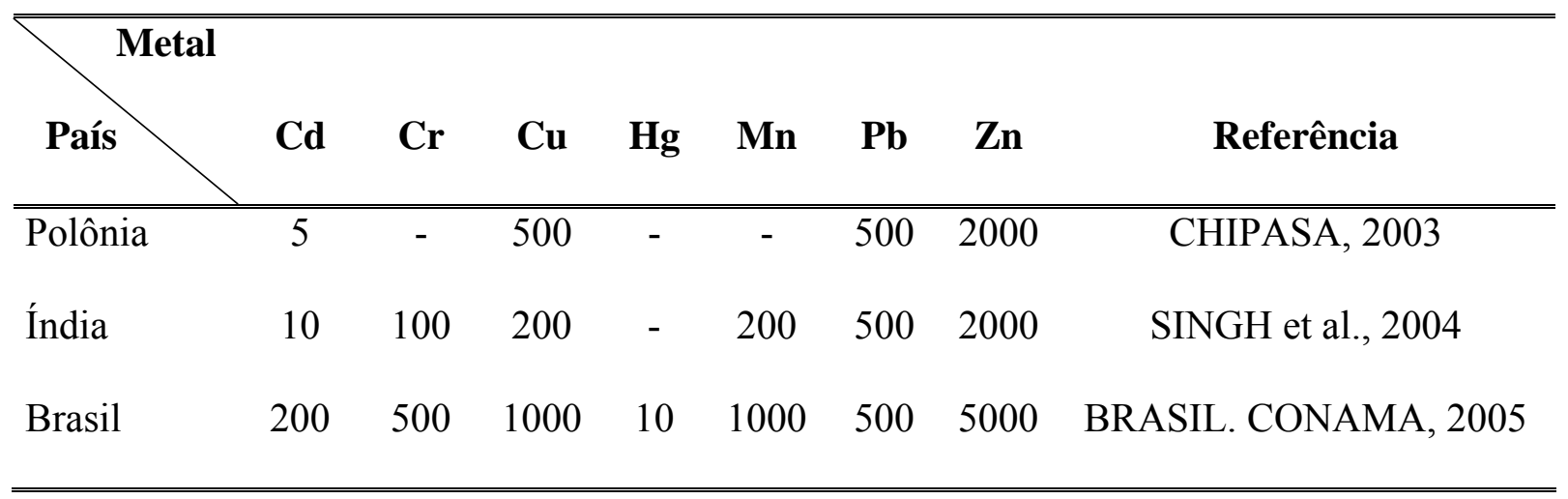

O efluente final gerado na ETE-Ribeirão Preto encontra-se, de acordo com os padrões estipulados pela Resolução CONAMA 357/05 (BRASIL. CONAMA, 2005), no referente aos níveis de metais, apresentando concentrações bem abaixo das permitidas. O efluente tratado na ETE-Ribeirão Preto é lançado no córrego Ribeirão Preto, classificado como corpo de água pertencente à classe 4 de acordo com o Decreto $n^{0} 10.755$, de 22/11/77, da CETESB, que dispõe sobre o enquadramento dos corpos de água e receptores no Estado de São Paulo (ANEXO C). De acordo com a Resolução CONAMA 357/05, que estabelece as condições e padrões de lançamento de efluentes, as águas doces de Classe 4 podem ser destinadas à navegação e à harmonia paisagística.

O Córrego Ribeirão Preto vai até a confluência com o Rio Pardo, pertencente à Classe 2, classificação para a qual se aplicam os mesmos padrões da Classe 1 (ANEXO C). Essas águas podem ser destinadas ao abastecimento humano, após tratamento convencional, à proteção das comunidades aquáticas, à recreação de contato aquático, tais como natação e outros, à irrigação de hortaliças e plantas em geral, e à aquicultura e à atividade de pesca. Conforme a Tabela 11, os níveis médios de $\mathrm{Cd}, \mathrm{Cr}, \mathrm{Cu}, \mathrm{Hg}, \mathrm{Mn}, \mathrm{Pb}$ e $\mathrm{Zn}$, analisados, estão dentro dos níveis máximos permitidos pelos padrões de qualidade de corpos de água pertencentes à Classe 4 da Resolução CONAMA 357/05 (BRASIL. CONAMA, 2005). No 
entanto, cabe destacar que o $\mathrm{Cu}$ e o $\mathrm{Pb}$ apresentaram valores máximos acima dos limites especificados pela referida Resolução.

Tabela 11 - Quadro comparativo dos padrões dos níveis de metais de corpos de água pertencentes à Classe 2 e Classe 4 da Resolução CONAMA 357/05 e os valores médios obtidos de esgoto tratado analisados na presente pesquisa, 2004

\begin{tabular}{cccc}
\hline \hline Metais & $\begin{array}{c}\text { Classe 2* } \\
\text { ug/L }\end{array}$ & $\begin{array}{c}\text { Classe } \mathbf{4}^{*} \\
\mathbf{u g} / \mathbf{L}\end{array}$ & $\begin{array}{c}\text { Média dos valores } \\
\text { obtidos no trabalho } \\
\text { ug/L }\end{array}$ \\
\hline $\mathrm{Cd}$ & 1,0 & 10,0 & 0,06 \\
$\mathrm{Cr}$ & 50,0 & 50,0 & 5,74 \\
$\mathrm{Cu}$ & 9,0 & 13,0 & 9,66 \\
$\mathrm{Mn}$ & 100,0 & 500,0 & 47,04 \\
$\mathrm{Hg}$ & 0,2 & 2,0 & 0,05 \\
$\mathrm{~Pb}$ & 10,0 & 33,0 & 22,57 \\
$\mathrm{Zn}$ & 180,0 & 5000 & 43,64 \\
\hline \hline
\end{tabular}

*Resolução CONAMA 357/05.

Deve ser considerado, também, que na ETE-Ribeirão Preto é captado o chorume do Aterro Sanitário de Ribeirão Preto (AMBIENT, 2005). O chorume é um líquido resultante da percolação da água através dos resíduos domésticos, dispostos em aterros sanitários em processo de decomposição, com altas concentrações de compostos orgânicos e inorgânicos. A composição físico-química do chorume é extremamente variável, dependendo de fatores tais como: condições pluviométricas locais, tempo de disposição e características do próprio lixo. O chorume pode conter altas concentrações de sólidos suspensos, metais pesados e compostos orgânicos, originados da degradação de substâncias que são metabolizadas como carboidratos, proteínas e gorduras (BERTAZZOLI; PELEGRINI, 2002).

O chorume apresenta características semelhantes às dos esgotos sanitários, com 
grande porcentagem de matéria orgânica biodegradável de difícil decantação, daí a aplicação de tratamentos biológicos como uma das soluções para o tratamento do chorume (SCHALCH, 1984).

Na cidade de Ribeirão Preto, o DAERP (Departamento de Água e Esgoto de Ribeirão Preto) é responsável pelo gerenciamento dos resíduos sólidos urbanos. A coleta de lixo doméstico atende $100 \%$ da população da cidade, sendo realizada em todos os bairros, inclusive favelas. Diariamente, são coletadas 480 toneladas de lixo em média, que são destinados ao aterro sanitário de Ribeirão Preto (RIBEIRÃO PRETO. PREFEITURA MUNICIPAL. DEPARTAMENTO DE ÁGUA E ESGOTO DE RIBEIRÃO PRETO. DAERP, 2005).

O chorume coletado nos tanques de captação do Aterro Sanitário de Ribeirão Preto é transportado, em caminhões-pipa, diariamente para a ETE-Ribeirão Preto. Cada caminhão tem capacidade de transportar $12 \mathrm{~m}^{3}$, sendo aceitos até quatro caminhões por dia na ETERibeirão Preto (AMBIENT, 2005).

Em estudo realizado por Celere et al. (2005), sobre níveis de metais no chorume do Aterro Sanitário de Ribeirão Preto, foram observados os seguintes valores médios nas amostras de chorume coletadas no módulo I: Cd 10 ug/L, Cr 175 ug/L, Mn 676 ug/L, Pb 2085 ug/L, Zn 8429 ug/L. No módulo II os valores foram: Cd 12 ug/L, Cr 164 ug/L, Mn 428 ug/L, $\mathrm{Pb} 2374$ ug/L, Zn 9146 ug/L. Os valores de Cu e Hg apresentaram-se abaixo dos limites de detecção, tanto nas amostras coletadas no módulo I quanto no módulo II. Pela Resolução n³57/2005 do CONAMA, os níveis de Cr, Cd, Cu, Mn e Hg encontram-se dentro dos limites máximos estabelecidos. No entanto, os valores médios de $\mathrm{Pb}$ e $\mathrm{Zn}$ apresentaram-se acima dos limites específicos pela referida Resolução.

A partir desses achados, considerava-se que a captação do chorume pudesse afetar o processo de tratamento da ETE-Ribeirão Preto, principalmente considerando os valores de 
$\mathrm{Pb}$ e $\mathrm{Zn}$. No entanto, pode ser observado que a adição do chorume no esgoto bruto não afetou as concentrações dos metais analisados na época, considera-se a possibilidade deles terem sido atenuados pela diluição no esgoto bruto. Conseqüentemente, as concentrações de metais na saída do esgoto também não foram afetadas.

Variações das concentrações dos metais nas amostras da entrada e da saída para cada dia coletado são apresentadas na Figura 21. Observações similares são relatadas por Oliver e Cosgrove (1974) que estudaram as variações das concentrações dos efluentes do esgoto. 
Cd
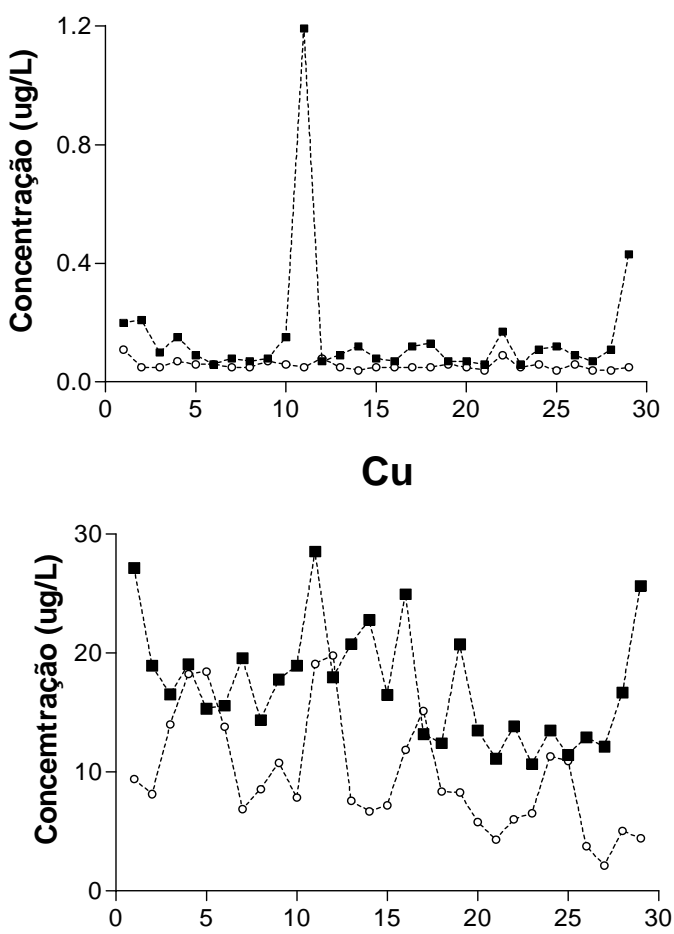

$\mathrm{Hg}$

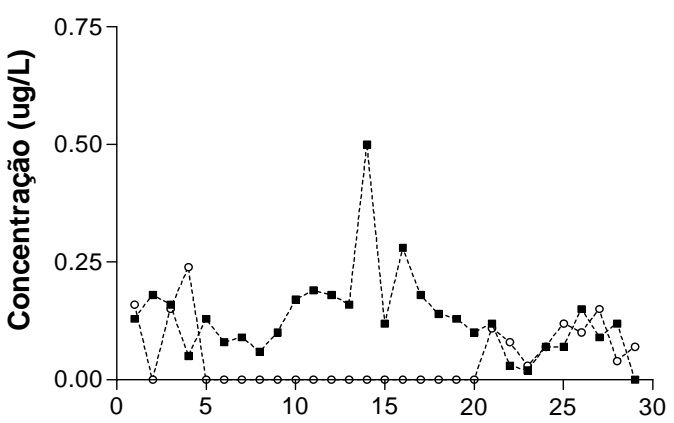

$\mathrm{Cr}$
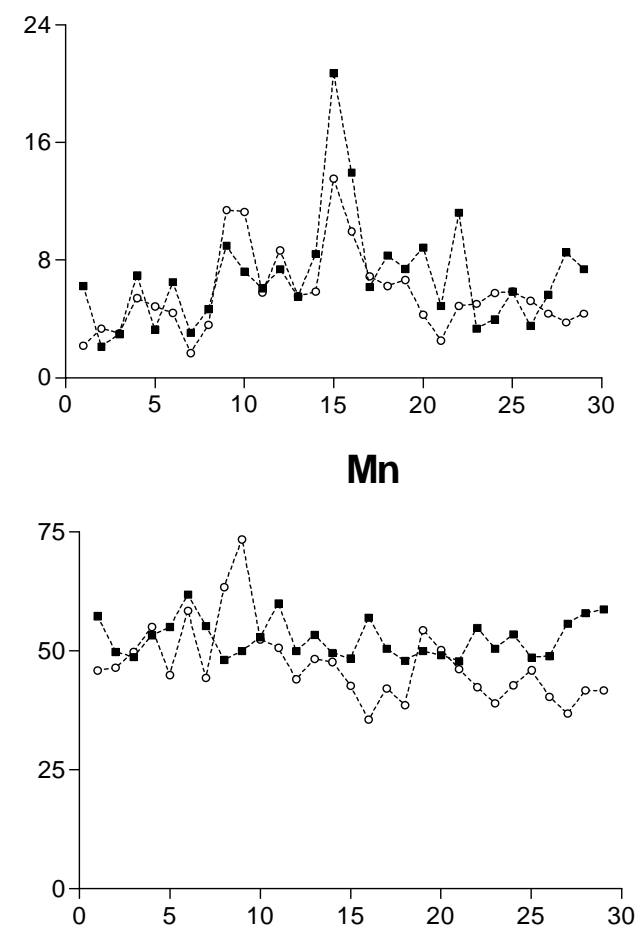

$\mathrm{Pb}$

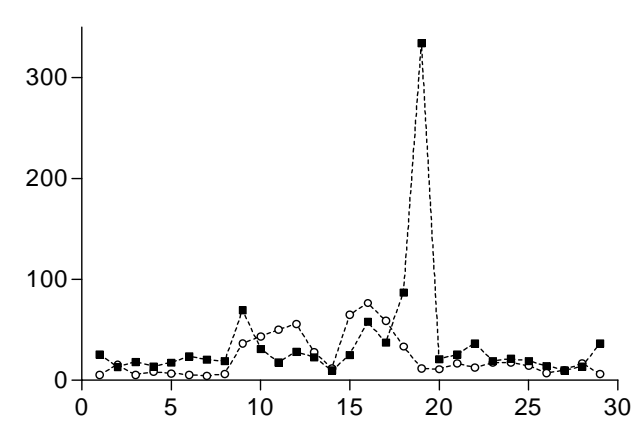

$\mathrm{Zn}$

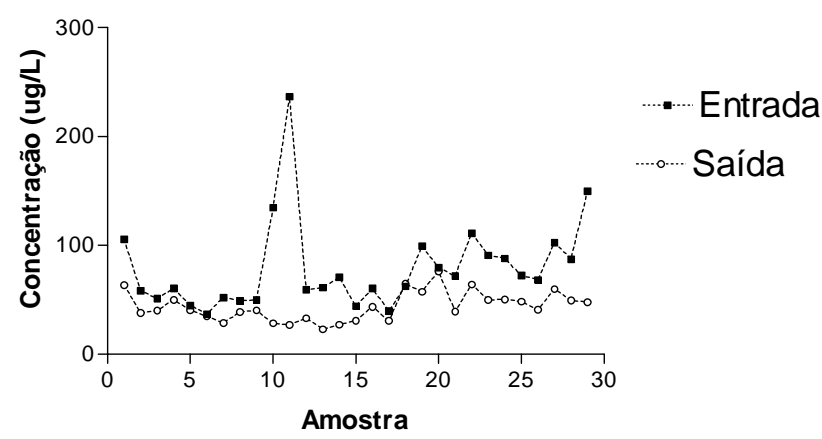

Figura 21 - Variações da concentração de metais na entrada e saída do esgoto da ETERibeirão Preto, 2004 
Analisando os gráficos da Figura 21 pode-se observar que, de maneira geral, as concentrações de metais variaram segundo o dia de coleta na entrada e na saída da ETERibeirão Preto-SP. Estudos evidenciaram que os níveis dos metais pesados no esgoto tratado são influenciados pela concentração inicial no esgoto não tratado (BROWN et al., 1973; CHENG; PATTERSON; MINEAR, 1975; NEUFELD; HERMANN, 1975; STOVELAND; LESTER, 1980; CHIPASA, 2003).

Avaliando a Figura 21, pode-se observar que as variações na concentração de metais pesados no efluente não tratado foram maiores que nas amostras do efluente tratado. As variações das concentrações de $\mathrm{Cr}, \mathrm{Cu}$ e $\mathrm{Mn}$ são mais pronunciadas que as variações dos níveis de $\mathrm{Cd}, \mathrm{Pb}, \mathrm{Hg}$ e $\mathrm{Zn}$. As concentrações de $\mathrm{Cd}$ e $\mathrm{Hg}$ nas amostras da saída foram as que permaneceram mais estáveis.

A porcentagem da remoção dos metais é apresentada na Figura 22. É necessário apontar que a remoção de metais pesados não é afetada somente pela espécie metálica e a concentração, mas, também, por outras condições como parâmetros de operação e fatores físicos, químicos e biológicos (BROWN; LESTER, 1979).

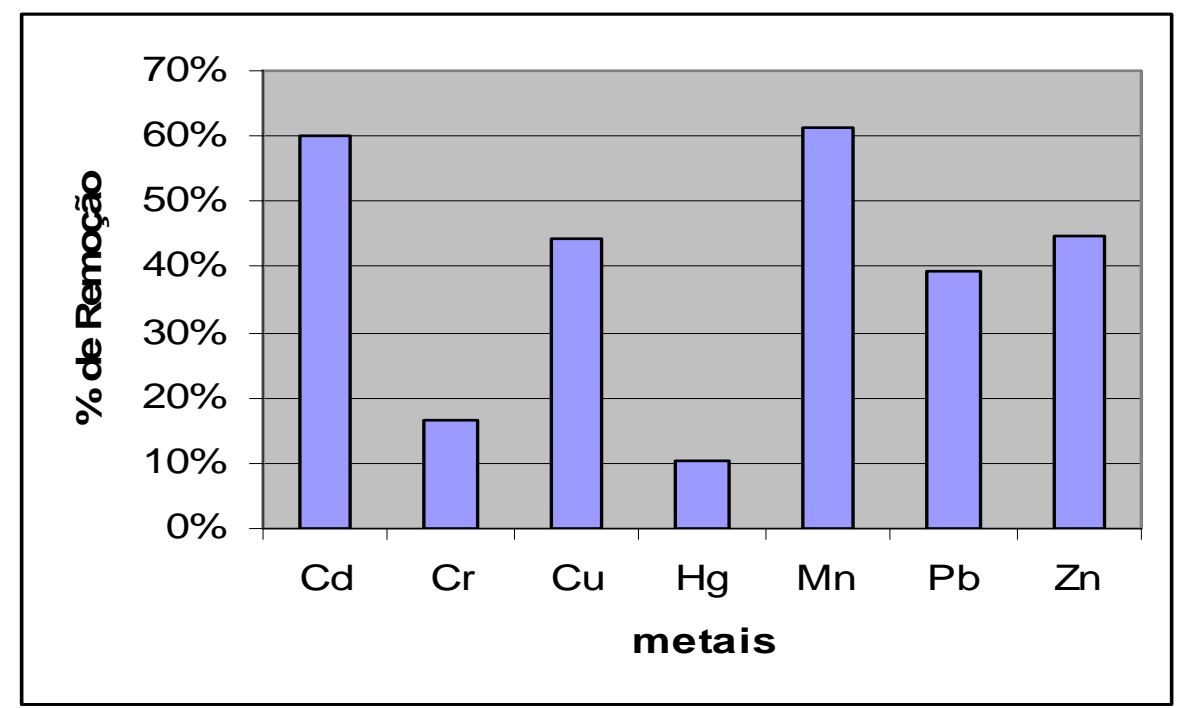

Figura 22 - Porcentagem de remoção dos níveis médios da entrada e saída da ETERibeirão Preto-SP 
Na Tabela 12 são mostrados os percentuais de remoção de metais em estações de tratamento de esgoto de acordo com estudos desenvolvidos em diferentes localidades no mundo.

Tabela 12 - Percentual da remoção de metais no esgoto não tratado e tratado de várias ETEs, segundo alguns estudos na literatura

\begin{tabular}{cccccccl}
\hline \hline Cd & Cr & Cu & Hg & Mn & Pb & Zn & Referências \\
\hline \hline 80 & 79 & 73 & - & 37 & 93 & 77 & OLIVER; COSGROVE, 1974 \\
62 & 46 & 80 & - & 39 & 88 & 63 & PETRASEK; KUGELMAN, 1983 \\
48 & 33 & 49 & - & - & 55 & 31 & PATTERSON; KODULULA, 1984 \\
88,4 & 95,8 & 76,5 & - & 67,2 & 86,1 & 92,5 & DAMASCENO, 1996
\end{tabular}

Fonte - Adaptada por Damasceno, 1996.

Sistemas biológicos de tratamento de esgotos são planejados, principalmente, para remover matéria orgânica através dos microorganismos presentes nos lodos ativados. A remoção de metais pesados por esses sistemas pode ser considerada como um efeito adicional, e tido como muito variável (OLIVER; COSGROVE, 1974; NEUFELD; HERMANN, 1975). É possível que a remoção de metais pesados ocorra tanto no tratamento primário, no qual a porção de metais adsorve as partículas, quanto no tratamento biológico secundário, no qual os metais são removidos por bioabsorção (BARTH et al., 1965; BROWN et al., 1973; OLIVER; COSGROVE, 1974).

Como pode ser observado pela comparação dos dados obtidos em outros estudos, os resultados da remoção foram muito variáveis para os diferentes metais, mas pode-se concluir que houve uma importante remoção dos mesmos.

A remoção de metais pesados nos sistemas biológicos depende da matéria orgânica dissolvida e da concentração de $\mathrm{pH}$ existente. Considera-se que a eficiência da remoção é 
maior ao aumentar-se o $\mathrm{pH}$, até os metais precipitarem-se como hidróxidos (WANG et al., 1999). O tratamento biológico de sistemas de esgotos é conduzido normalmente com pH entre 7 e 9. Neste estudo, os valores de $\mathrm{pH}$ para as amostras dos esgotos não tratados variaram de 6,34 a 7,34, sob temperaturas de 24,3 a $27,3^{\circ} \mathrm{C}$. Uma vez que a composição das águas residuárias é complexa e bastante variada, as variações observadas na redução do conteúdo de metais pesados são também atribuídas às variações de pH (BROWN et al., 1973; CHENG; PATTERSON; MINEAR, 1975; CHIPASA, 2003).

$\mathrm{Na}$ Tabela 13, são apresentados os valores médios de $\mathrm{pH}$ e temperatura, registrados nos diferentes dias em que foram realizadas as coletas de amostras no esgoto bruto.

Tabela 13 - Valores médios diários do nível do $\mathrm{pH}$ e da temperatura do esgoto bruto da ETE-Ribeirão Preto-SP, em 2004

\begin{tabular}{ccc}
\hline \hline Data da leitura & $\mathbf{p H}$ & Temperatura \\
\hline \hline $28 / 06$ & 7,34 & 25,4 \\
$29 / 06$ & 7,02 & 26,2 \\
$30 / 06$ & 7,13 & 24,9 \\
$01 / 07$ & 6,43 & 25,3 \\
$02 / 07$ & 7,23 & 25,7 \\
$03 / 07$ & 7,02 & 25,4 \\
$05 / 07$ & 6,67 & 27,3 \\
$06 / 07$ & 6,34 & 25,8 \\
$07 / 07$ & 6,43 & 25,4 \\
$08 / 07$ & 6,65 & 25,3 \\
$13 / 07$ & 7,20 & 25,7 \\
$14 / 07$ & 6,43 & 25,4 \\
$15 / 07$ & 6,45 & 26,2 \\
$16 / 07$ & 6,53 & 25,3 \\
$17 / 07$ & 6,76 & 25,5 \\
$19 / 07$ & 6,75 & 24,7 \\
$20 / 07$ & 6,78 & 24,9 \\
$21 / 07$ & 6,46 & 25,8 \\
$22 / 07$ & 6,53 & 24,5 \\
$23 / 07$ & 7,23 & 25,5 \\
$26 / 07$ & 7,02 & 25,3 \\
$27 / 07$ & 7,20 & 25,7 \\
$28 / 07$ & 7,21 & 25,4 \\
& & \\
& &
\end{tabular}




\begin{tabular}{ccc}
$29 / 07$ & 7,03 & 26,2 \\
$30 / 07$ & 7,25 & 24,9 \\
$02 / 08$ & 6,87 & 24,7 \\
$03 / 08$ & 6,98 & 25,8 \\
$04 / 08$ & 6,87 & 24,3 \\
$05 / 08$ & 7,02 & 24,7 \\
$06 / 08$ & 7,24 & 25,8 \\
\hline \hline Média $\pm \mathbf{D P}$ & $\mathbf{6 , 8 7} \pm \mathbf{0 , 3 1}$ & $\mathbf{2 5 , 4} \pm \mathbf{0 , 6 1}$ \\
\hline \hline
\end{tabular}

\subsection{Lodo}

A palavra lodo, torta ou sólidos, segundo a WEF (Water Environment Federation), é para o lodo bruto, primário ou secundário ainda não submetido a nenhum processo de estabilização biológica. Já o termo biossólido tem sido recomendado para designar o lodo tratado ou beneficiado de ETEs (TSUTIYA, 1999).

O lodo constitui o principal subproduto do tratamento das águas residuárias. A disposição sanitária ou utilização desse subproduto é um dos mais importantes problemas associados ao projeto e ao gerenciamento das Estações de Tratamento de Esgotos (CHAGAS, 2000).

A partir de 1980, a Commission of European Communities (CEC), regulamentou a padronização de estritas limitações à utilização do lodo no solo, em países da Comunidade Européia, estabelecendo as seguintes diretrizes básicas:

- o lodo não deve ser utilizado quando apresentar concentrações de poluentes, acima dos estabelecidos;

- o lodo fresco (não estabilizado) só poderá ser utilizado no solo, se for imediatamente nele injetado;

- nenhuma aplicação deverá ser feita em parques, play-grounds, ou em matas e florestas; 
- áreas gramadas não deverão ser utilizadas como pastagens, e as forragens não deverão ser colhidas para alimentação de animais por, pelo menos, seis semanas após a aplicação do lodo estabilizado;

- não deverá ser aplicado lodo em culturas que possam entrar em contato direto com esse e que sejam consumidas cruas;

- o lodo não deverá ser aplicado em solos que apresentarem valor de pH menor que 6,0, após a aplicação (VICENT; CRITCHLEY, 1984).

As amostras de lodo foram coletadas em dias alternados, de acordo com a geração desse subproduto na ETE-Ribeirão Preto, logo depois de realizada a desidratação do lodo, no período de 28/06/04 a 06/08/04.

Os resultados obtidos das análises de $\mathrm{As}, \mathrm{Be}, \mathrm{Cd}, \mathrm{Cr}, \mathrm{Cu}, \mathrm{Fe}, \mathrm{Hg}, \mathrm{Mn}, \mathrm{Ni}, \mathrm{Pb}, \mathrm{St}$, TI, V e Zn nas amostras de lodo, coletadas na ETE-Ribeirão Preto, são apresentados na Tabela 14 e Tabela 15.

A Tabela 16, apresenta os resultados estatísticos: média, desvio padrão, mediana, valor mínimo e máximo, e coeficiente de variação para os 14 metais analisados. A ordem crescente da concentração dos metais é a seguinte: $\mathrm{Tl}<\mathrm{Hg}<\mathrm{Be}<\mathrm{As}<\mathrm{Cd}<\mathrm{V}<\mathrm{Pb}<\mathrm{Sn}<\mathrm{Cr}<\mathrm{Mn}<\mathrm{Ni}<\mathrm{Cu}<\mathrm{Zn}<\mathrm{Fe}$. 
Tabela 14 - Concentração de metais nas amostras coletadas do lodo da ETE-Ribeirão Preto $(\mathrm{mg} / \mathrm{kg})$

\begin{tabular}{|c|c|c|c|c|c|c|c|}
\hline & As* & Be* $^{*}$ & Cd* & Crr** & $\overline{\mathbf{C u}} \mathbf{u}^{* *}$ & Fe** $^{* *}$ & "Hg* \\
\hline$\overline{1} 1$ & $\bar{~} 1,15$ & 0,35 & 21,30 & 187,28 & 353,08 & 1818885,60 & $0,0,28$ \\
\hline 2 & 1,03 & 0,43 & 1,18 & 173,14 & 342,07 & 18831,28 & 0,23 \\
\hline 3 & 1,13 & 0,57 & 1,15 & 179,74 & 377,12 & 20190,49 & 0,23 \\
\hline 4 & 1,22 & 0,32 & 1,28 & 194,25 & 380,26 & 21023,28 & 0,25 \\
\hline 5 & 1,11 & 0,34 & 1,31 & 194,46 & 406,01 & 21848,24 & 0,17 \\
\hline 6 & 1,33 & 0,42 & 2,14 & 209,85 & 409,96 & 21956,83 & 0,22 \\
\hline 7 & 1,17 & 0,45 & 1,27 & 198,01 & 392,40 & 21091,64 & 0,16 \\
\hline 8 & 1,10 & 0,46 & 1,25 & 186,07 & 396,40 & 21117,91 & 0,19 \\
\hline 9 & 1,17 & 0,31 & 1,69 & 190,91 & 387,72 & 20850,72 & 0,17 \\
\hline 10 & 1,19 & 0,32 & 1,22 & 186,98 & 385,95 & 21538,59 & 0,15 \\
\hline 11 & 1,04 & 0,39 & 1,20 & 178,24 & 337,44 & 18782,93 & 0,12 \\
\hline 12 & 1,29 & 0,49 & 1,29 & 203,15 & 402,45 & 22029,20 & 0,18 \\
\hline 13 & 1,08 & 0,40 & 1,23 & 180,87 & 365,41 & 19407,89 & 0,11 \\
\hline 14 & 1,03 & 0,34 & 1,34 & 181,16 & 381,18 & 19560,67 & 0,13 \\
\hline 15 & 1,02 & 0,46 & 1,22 & 177,78 & 362,06 & 18745,75 & 0,13 \\
\hline 16 & 1,06 & 0,38 & 1,14 & 162,89 & 332,89 & 17165,82 & 0,12 \\
\hline 17 & 1,23 & 0,45 & 1,28 & 187,94 & 385,99 & 22030,05 & 0,87 \\
\hline 18 & 0,98 & 0,53 & 1,15 & 175,56 & 374,61 & 20349,66 & 0,64 \\
\hline 19 & 1,20 & 0,53 & 1,39 & 212,73 & 415,85 & 21625,88 & 0,61 \\
\hline 20 & 1,23 & 0,42 & 1,47 & 207,94 & 418,12 & 21014,49 & 0,51 \\
\hline 21 & 1,21 & 0,48 & 1,36 & 224,79 & 430,29 & 22628,75 & 0,48 \\
\hline 22 & 1,20 & 0,53 & 1,53 & 215,14 & 435,09 & 21491,83 & 0,46 \\
\hline 23 & 1,17 & 0,48 & 1,36 & 205,08 & 408,15 & 20059,42 & 0,45 \\
\hline 24 & 1,11 & 0,52 & 1,33 & 223,51 & 442,65 & 22492,73 & 0,39 \\
\hline 25 & 1,19 & 0,47 & 1,42 & 218,25 & 430,27 & 21484,23 & 0,38 \\
\hline 26 & 1,15 & 0,48 & 1,40 & 212,50 & 415,80 & 19904,82 & 0,32 \\
\hline 27 & 1,08 & 0,28 & 1,17 & 200,55 & 405,27 & 19412,30 & 0,33 \\
\hline 28 & 1,16 & 0,45 & 1,26 & 208,19 & 412,78 & 20643,51 & 0,31 \\
\hline 29 & 1,05 & 0,43 & 1,10 & 184,40 & 379,30 & 20583,39 & 0,27 \\
\hline 30 & 1,06 & 0,47 & 1,71 & 189,32 & 383,70 & 19370,37 & 0,33 \\
\hline
\end{tabular}

Amostras determinadas por *(ICP-MS), $* *(\mathrm{ICP}-\mathrm{OES}) * * *$ (AAS-FG). 
Tabela 15 - Concentração de metais nas amostras coletadas do lodo da ETE-Ribeirão Preto $(\mathrm{mg} / \mathrm{kg})$

\begin{tabular}{|c|c|c|c|c|c|c|c|}
\hline & Mn* & Ni*** & Pb* & Sn* & TI* & $\overline{\mathbf{V}^{*}}$ & Zn** \\
\hline$\overline{c 1}$ & 202,51 & 226,79 & 121,40 & 135,59 & $\overline{00,00}$ & $\begin{array}{l}59,01 \\
\end{array}$ & 816,78 \\
\hline 2 & 189,08 & 263,24 & 115,18 & 173,80 & 0,00 & 54,79 & 787,21 \\
\hline 3 & 199,24 & 228,59 & 118,54 & 152,37 & 0,00 & 57,36 & 834,75 \\
\hline 4 & 215,42 & 228,98 & 130,67 & 153,74 & 0,00 & 59,97 & 856,32 \\
\hline 5 & 216,43 & 228,17 & 131,06 & 155,97 & 0,00 & 61,36 & 938,15 \\
\hline 6 & 231,71 & 239,69 & 139,91 & 129,28 & 0,00 & 65,97 & 928,64 \\
\hline 7 & 222,64 & 248,00 & 127,28 & 160,90 & 0,00 & 62,36 & 894,12 \\
\hline 8 & 208,73 & 244,81 & 124,29 & 164,12 & 0,01 & 57,31 & 910,67 \\
\hline 9 & 212,05 & 229,96 & 127,46 & 136,86 & 0,00 & 59,96 & 882,96 \\
\hline 10 & 209,56 & 230,03 & 124,83 & 175,93 & 0,00 & 59,40 & 874,25 \\
\hline 11 & 193,03 & 203,85 & 119,29 & 173,29 & 0,00 & 54,31 & 781,11 \\
\hline 12 & 223,75 & 214,89 & 135,42 & 165,41 & 0,00 & 62,82 & 903,07 \\
\hline 13 & 204,34 & 211,30 & 122,69 & 173,42 & 0,00 & 57,21 & 796,11 \\
\hline 14 & 204,34 & 207,13 & 121,60 & 166,25 & 0,00 & 55,87 & 808,15 \\
\hline 15 & 199,64 & 220,20 & 119,68 & 214,59 & 0,00 & 54,83 & 787,00 \\
\hline 16 & 179,80 & 248,26 & 110,23 & 215,47 & 0,00 & 50,48 & 727,17 \\
\hline 17 & 225,30 & 221,99 & 129,90 & 171,90 & 0,00 & 63,85 & 851,82 \\
\hline 18 & 201,74 & 218,10 & 124,08 & 156,44 & 0,00 & 57,43 & 832,22 \\
\hline 19 & 219,06 & 238,76 & 137,40 & 168,96 & 0,00 & 60,76 & 936,61 \\
\hline 20 & 215,51 & 254,76 & 138,57 & 158,16 & 0,00 & 62,00 & 887,19 \\
\hline 21 & 239,83 & 265,76 & 153,29 & 138,10 & 0,00 & 66,18 & 971,56 \\
\hline 22 & 230,60 & 266,01 & 143,11 & 144,94 & 0,00 & 62,82 & 931,03 \\
\hline 23 & 200,78 & 238,49 & 137,98 & 168,49 & 0,00 & 58,89 & 879,32 \\
\hline 24 & 219,68 & 325,80 & 156,69 & 151,70 & 0,00 & 62,60 & 954,08 \\
\hline 25 & 209,33 & 252,93 & 145,70 & 180,06 & 0,00 & 60,47 & 928,00 \\
\hline 26 & 203,08 & 291,52 & 144,81 & 196,63 & 0,00 & 59,77 & 891,92 \\
\hline 27 & 189,17 & 234,13 & 138,72 & 176,77 & 0,00 & 55,96 & 860,15 \\
\hline 28 & 198,96 & 234,79 & 148,61 & 193,80 & 0,00 & 60,21 & 873,48 \\
\hline 29 & 190,03 & 229,08 & 137,49 & 198,27 & 0,00 & 57,85 & 789,06 \\
\hline 30 & 186,87 & 237,25 & 136,63 & 132,67 & 0,00 & 55,50 & 820,09 \\
\hline
\end{tabular}

Amostras determinadas por *(ICP-MS), **(ICP-OES) *** (AAS-FG). 
Tabela 16 - Concentração de metais nas amostras de lodo coletadas na ETE-RP, 2004, expressa em $\mathrm{mg} / \mathrm{kg}$

\begin{tabular}{|c|c|c|c|c|c|c|}
\hline Metal & Média & $\begin{array}{l}\text { Desvio } \\
\text { padrão }\end{array}$ & Mediana & $\begin{array}{c}\text { Valor } \\
\text { mínimo }\end{array}$ & $\begin{array}{c}\text { Valor } \\
\text { máximo }\end{array}$ & 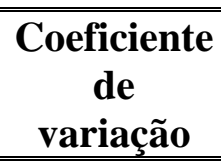 \\
\hline As & 1,14 & 0,08 & 1,15 & 0,98 & 1,33 & 7,02 \\
\hline $\mathrm{Be}$ & 0,43 & 0,08 & 0,45 & 0,28 & 0,57 & 18,60 \\
\hline $\mathrm{Cd}$ & 1,34 & 0,21 & 1,29 & 1,10 & 2,14 & 15,67 \\
\hline $\mathrm{Cr}$ & 195,02 & 16,13 & 192,58 & 162,89 & 224,79 & 8,27 \\
\hline $\mathrm{Cu}$ & 391,67 & 28,69 & 390,06 & 332,89 & 442,65 & 7,33 \\
\hline Fé & 20537,28 & 1320,06 & 20747,12 & 17165,82 & 22628,75 & 6,43 \\
\hline $\mathrm{Hg}$ & 0,31 & 0,18 & 0,26 & 0,11 & 0,87 & 58,06 \\
\hline $\mathrm{Mn}$ & 208,07 & 14,64 & 206,54 & 179,80 & 239,83 & 7,04 \\
\hline $\mathrm{Ni}$ & 239,44 & 25,20 & 234,46 & 203,85 & 325,80 & 10,52 \\
\hline $\mathrm{Pb}$ & 132,08 & 11,56 & 130,87 & 110,23 & 156,69 & 8,75 \\
\hline Sn & 166,13 & 22,34 & 165,83 & 129,28 & 215,47 & 13,45 \\
\hline $\mathrm{Tl}$ & $<0,03$ & - & - & $<0,03$ & $<0,03$ & - \\
\hline V & 59,24 & 3,59 & 59,58 & 50,48 & 66,18 & 6,06 \\
\hline $\mathrm{Zn}$ & 864,43 & 60,73 & 873,87 & 727,17 & 971,56 & 7,03 \\
\hline
\end{tabular}

A variação das concentrações de metais em amostras de lodo formado pela ETERibeirão Preto-SP, no ano de 2004, são mostrados na Figura 23. O Tl não está representado, visto que suas concentrações são menores que os limites de detecção. As variações de $\mathrm{Cd}, \mathrm{Hg}$, $\mathrm{Sn}$ e $\mathrm{Cr}$, contidas no lodo, são maiores do que as variações de $\mathrm{As}, \mathrm{Be}, \mathrm{V}, \mathrm{Pb}, \mathrm{Ni}, \mathrm{Zn}, \mathrm{Cu}, \mathrm{Mn}$ e Fe. As variações das concentrações de $\mathrm{Cd}$ e $\mathrm{Hg}$ são as maiores de todas, contrastando com $\mathrm{Mn}$ e V de acordo com o dia que as amostras foram coletadas e suas concentrações $(\mathrm{mg} / \mathrm{kg})$. 

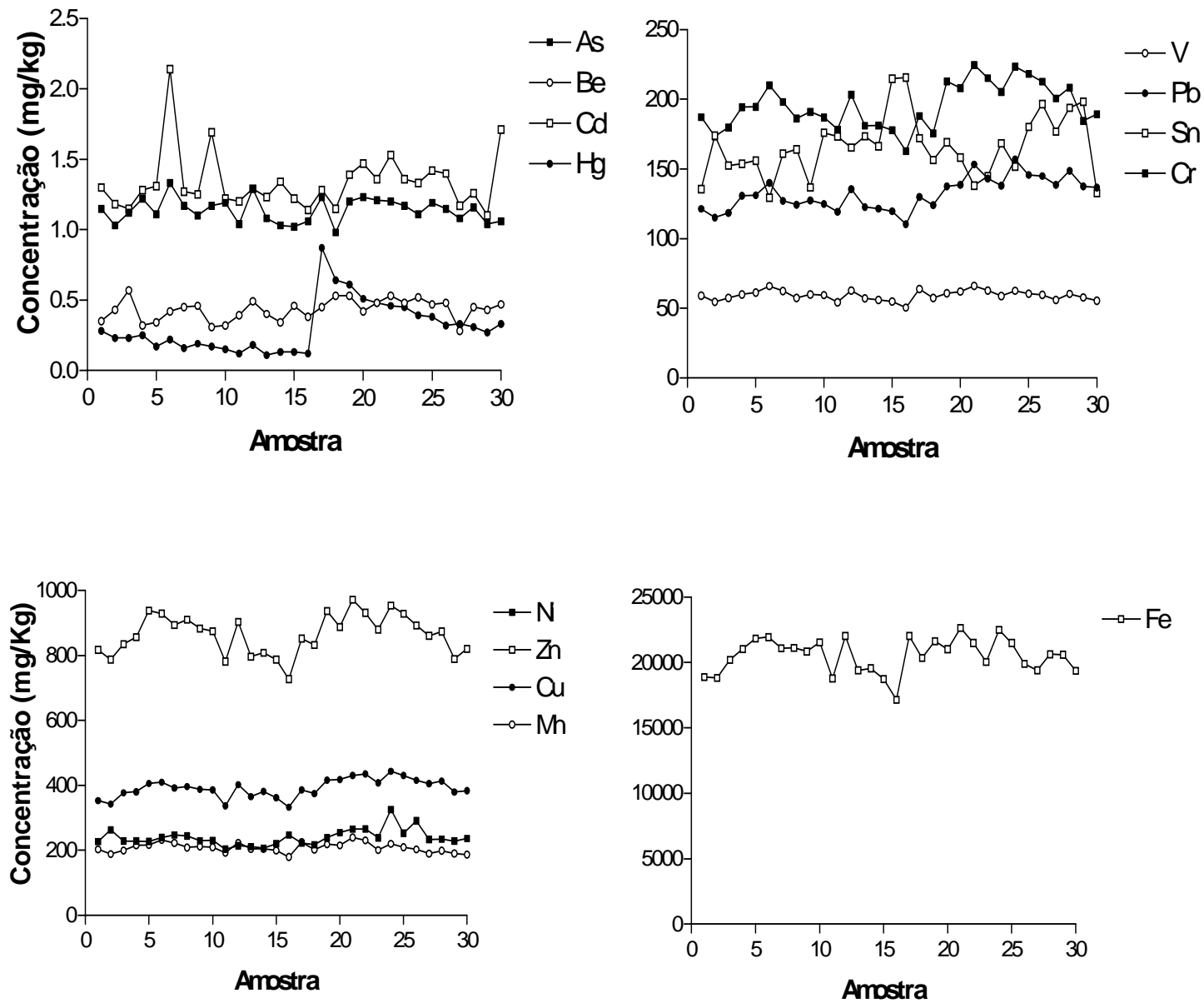

Figura 23 - Variações das concentrações de metais pesados nas amostras de lodo, coletadas de junho a agosto de 2004

Pode-se verificar que os valores de metais pesados analisados no lodo estão dentro dos níveis máximos permitidos, e previamente estabelecidos pela Companhia de Tecnologia de Saneamento Ambiental de São Paulo, para o lodo destinado à agricultura (SÃO PAULO. CETESB, 2001). Esses valores estão de acordo com as normas internacionais, como legislações européias (EUROPEAN. Council Directive 86/278/EEC), dos Estados Unidos (US EPA, 1983) e também próximos de várias legislações de outros países, apresentados na Tabela 17. 
Tabela 17 - Recomendações internacionais de valores máximos permitidos de metais pesados no lodo de esgoto para uso na agricultura $(\mathrm{mg} / \mathrm{kg})$, de acordo com suas referidas fontes

\begin{tabular}{|c|c|c|c|c|c|c|c|c|c|c|c|c|c|c|c|}
\hline Metal & $\begin{array}{l}A \\
\text { s }\end{array}$ & $\begin{array}{l}\mathbf{B} \\
\mathbf{e}\end{array}$ & $\overline{C \text { Cd }}$ & $\overline{\mathrm{Cr}}$ & $\overline{\mathbf{C u}}$ & $\overline{\mathbf{P b}}$ & $\begin{array}{l}\text { F } \\
\text { e }\end{array}$ & $\overline{\mathrm{Hg}}$ & $\overline{\mathrm{Ni}}$ & $\begin{array}{l}\text { S } \\
\text { n }\end{array}$ & $\overline{T l}$ & $\overline{\mathrm{V}}$ & $\overline{Z Z n}$ & $\overline{\text { Mn }}$ & Referências \\
\hline $\begin{array}{l}\text { Brasil } \\
\text { SP }\end{array}$ & 75 & $\overline{-1}$ & 85 & - & 4300 & 840 & - & 57 & 420 & - & - & 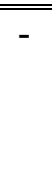 & 7500 & $\overline{-1}$ & $\begin{array}{l}\text { SÃO } \\
\text { PAULO. } \\
\text { CETESB, } \\
2001\end{array}$ \\
\hline Brasil - PR & - & - & 20 & - & 1000 & 750 & - & 16 & 300 & - & & & 2500 & - & $\begin{array}{l}\text { PARANÁ. } \\
\text { SANEPAR, } \\
1999\end{array}$ \\
\hline USA & 75 & - & 85 & 3000 & 4300 & 840 & - & 57 & 420 & - & - & - & 7500 & & $\begin{array}{lr}\text { US. } & \text { EPA, } \\
\text { CFR } & 503, \\
1994 & \end{array}$ \\
\hline CEC & - & - & 40 & 1500 & 1750 & 1200 & - & 25 & 400 & - & - & - & 4000 & - & $\begin{array}{l}\text { EUROPEAN } \\
\text { 278/ EEC, } \\
1986\end{array}$ \\
\hline Áustria & - & - & 3 & 250 & 500 & 250 & - & - & 100 & - & - & - & 1200 & - & $\begin{array}{l}\text { VOUTSA et } \\
\text { al., } 1996\end{array}$ \\
\hline Bélgica & - & - & 5 & 200 & 500 & 1000 & - & - & 100 & - & - & - & 1500 & - & $\begin{array}{l}\text { VOUTSA et } \\
\text { al., } 1996\end{array}$ \\
\hline Alemanha & - & - & 10 & 900 & 800 & 900 & - & - & 200 & - & - & - & 2500 & - & $\begin{array}{l}\text { ABDEL- } \\
\text { SHAFY; } \\
\text { HEGEMAN } \\
\text { N; } \\
\text { GULDNER, } \\
1996\end{array}$ \\
\hline França & - & - & 20 & 1000 & 1000 & 800 & - & - & 200 & - & - & - & 3000 & - & $\begin{array}{l}\text { PLANQUA } \\
\text { RT et al., } \\
1999\end{array}$ \\
\hline $\begin{array}{l}\text { Luxembur } \\
\text { go }\end{array}$ & - & - & 1.5 & 100 & 100 & 150 & - & - & 50 & - & - & - & 400 & - & $\begin{array}{l}\text { VOUTSA et } \\
\text { al., } 1996\end{array}$ \\
\hline Holanda & - & - & 1 & 50 & 75 & 100 & - & - & 30 & - & - & - & 200 & - & $\begin{array}{l}\text { CORNU et } \\
\text { al., } 2001\end{array}$ \\
\hline Espanha & - & - & 10 & 400 & 50 & 300 & - & - & 120 & - & - & - & 1100 & - & $\begin{array}{l}\text { VOUTSA et } \\
\text { al., } 1996\end{array}$ \\
\hline Itália & - & - & 10 & 600 & 600 & 500 & - & - & 200 & - & - & - & 2500 & - & $\begin{array}{l}\text { LAZZARI et } \\
\text { al., } 2000\end{array}$ \\
\hline Eslovênia & - & - & 5 & 500 & 600 & 500 & - & - & 80 & - & - & - & 2000 & - & $\begin{array}{l}\text { SCANCAR } \\
\text { et al., } 2000\end{array}$ \\
\hline Japão & 50 & - & 5 & - & - & - & - & 2 & - & - & - & - & - & - & $\begin{array}{l}\text { NOGUCHI; } \\
\text { ITO, } 1992\end{array}$ \\
\hline
\end{tabular}

Nota: Adaptado de Karvelas; Katsoyiannis; Samara (2003).

Constata-se que o lodo, gerado na ETE-RP, está em conformidade com $70 \%$ das legislações de países/localidades e bibliografias utilizadas no desenvolvimento do presente 
trabalho.

$\mathrm{Na}$ década de 70, devido às diversas práticas de destino final de lodo sem estudos adequados, pouco controle ambiental existia, então, regulamentou-se o lançamento do lodo no ambiente através de convenções internacionais (Convenção de Oslo, 1972; Convenção de Londres, 1972 e Convenção de Paris, 1974). Já, na época, confirmou-se que nem todo lodo poderia ser utilizado para aplicação na melhoria de solos agrícolas, dada a possibilidade de haver elementos poluentes no lodo, como organismos patogênicos e metais pesados, preocupando a comunidade científica. Nesse contexto, criou-se a Comunidade Européia para estudar o problema (VICENT; CRITCHLEY, 1984).

Para o lodo produzido numa ETE, as fases de adensamento (quando necessárias), estabilização e desidratação devem ser compatíveis entre si e coerentes com o destino final a ser dado ao lodo. Se o destino do lodo for o uso agrícola, o nível de patógenos, metais e seu potencial de geração de odores são de extrema importância. De acordo com a US. Environmental Protection Agency - EPA (1983), o grau de estabilização do lodo é muito importante para reciclagem agrícola, moderadamente importante para disposição em aterro sanitário e transporte em geral, e sem importância quando o destino final é incineração.

Com o objetivo de atenuar os incovenientes de odor das ETEs, bem como a presença de patógenos no lodo, são empregados processos químicos, físicos e biológicos, que utilizam vários mecanismos de atuação. $\mathrm{Na}$ estabilização biológica são utilizados os mecanismos naturais de biodegradação que transformam a parte mais putrescível do lodo. A via pode ser anaeróbia ou aeróbia. No caso da estação em estudo, é a digestão aeróbia, é a base conceitual dos sistemas do tipo aeração prolongada (MALTA, 2001).

Segundo a Empresa Brasileira de Pesquisa Agropecuária (EMBRAPA, 2000), o mecanismo da estabilização do lodo é a biodegradação de componentes orgânicos pelos organismos aeróbios. A fase final do processo é caracterizada pela respiração endógena, 
quando o substrato é totalmente consumido e os microorganismos passam a consumir o próprio plasma microbiano para obter energia para suas relações celulares. Portanto, o processo de digestão aeróbia passa pela oxidação direta da matéria orgânica biodegradável e, conseqüentemente, aumento da biomassa bacteriana e, posteriormente, pela oxidação do material microbiano celular pelos próprios microorganismos.

O desaguamento de lodo, conhecido como desidratação, é uma operação que reduz o volume do lodo em excesso por meio da redução do seu teor de água. A capacidade de desaguamento varia de acordo com o tipo de lodo, no caso dos lodos ativados, é mais fácil de ser desaguado do que um lodo primário digerido anaerobicamente. As razões para o desaguamento são: redução do custo de transporte para o local de disposição final, melhoria nas condições de manejo do lodo, aumento do poder calorífico do lodo por meio da redução de umidade com vistas à preparação para incineração e redução do volume para disposição em aterro sanitário, ou uso na agricultura (MALTA, 2001).

Nos EUA, a regulamentação para lançamento de lodo de esgotos nos solos só foi promulgada em 1993, por meio de um importante regulamento federal denominado 40 CFR (Code of Federal Regulations) que, na sua parte 503, determina os padrões norte-americanos para uso ou disposição de lodos produzidos por ETEs municipais. Quanto às limitações para metais no lodo, a legislação americana estabelece que em nenhuma hipótese é aceita a aplicação de lodo com concentrações superiores às estabelecidas. Quando prevista aplicação de lodo a granel, o gerador deverá solicitar autorização ao órgão ambiental para cada aplicação específica, tendo em vista os limites de acumulação de metais. Quando o lodo for embalado e vendido, ou doado para aplicação no solo, a exigência é que as concentrações de metais no lodo não podem exceder às concentrações indicadas (HUNT et al., 1994).

No Brasil, especificamente em São Paulo, o projeto P 4230 da CETESB, (SÃO PAULO. CETESB, 2001), foi adaptado das normas utilizadas nos Estados Unidos 
integralmente, prevendo também a necessidade de se respeitar os limites de acumulação de metais pesados por meio de controle das concentrações de metais no solo. Conta-se também, no país, com a SANEPAR que vem utilizando o biossólido na agricultura com determinação de valores máximos (PARANÁ. SANEPAR, 1999).

As concentrações de metais pesados analisados no lodo da ETE-RP e referenciados na literatura científica estão listados na Tabela 18, revelando que concentrações variáveis dos metais analisados no esgoto dependem, principalmente, do tipo de esgoto e da performance de cada planta de tratamento (ANGELIDIS; GIBBS, 1989; ABDEL-SHAFY; HEGEMANN; GULDNER, 1996; SCANCAR et al., 2000; CHIPASA, 2003).

Tabela 18 - Concentrações de valores máximos de metais pesados no lodo de esgoto de várias ETEs $(\mathrm{mg} / \mathrm{kg})$

\begin{tabular}{ccccccccl}
\hline \hline $\mathbf{C d}$ & $\mathbf{C r}$ & $\mathbf{C u}$ & $\mathbf{F e}$ & $\mathbf{P b}$ & $\mathbf{N i}$ & $\mathbf{Z n}$ & $\mathbf{M n}$ & \multicolumn{1}{c}{ Referências } \\
\hline \hline 4 & 128 & 147 & 46000 & 155 & 34 & 1878 & 308 & VOUTSA et al., 1996 \\
2.1 & - & 370 & - & 72 & 19 & 1500 & - & LAZZARI et al., 2000 \\
55.7 & 1228 & 755 & 58328 & 930 & 260 & 12064 & 3165 & BODZEK et al., 1997 \\
2.78 & 841 & 436 & 22445 & 128 & 622 & 2049 & - & SCANCAR et al., 2000 \\
1.81 & 60.5 & - & - & 35.9 & 43.5 & - & - & BARALIKIEWICZ; SIEPAK, 2001 \\
- & 100 & 315.5 & - & 54.2 & 11.9 & 679.9 & - & PEREZ et al., 2001 \\
- & - & 1403 & - & 412 & 967 & - & - & CORNU et al., 2001 \\
2 & 552 & 258 & 5098 & 326 & 41 & 1739 & 150 & ZORPAS et al., 2000 \\
- & - & 934 & - & 118 & 221 & 1574 & - & BRAGATO et al., 1998 \\
1.82 & 34 & 287 & - & 69 & - & 933 & - & MADONI; DAVOLI; \\
& & & & & & & & GUGLIELMI, 1999 \\
- & - & 167 & - & 75 & - & 254 & - & PLANQUART et al., 1999 \\
9.2 & 439 & 326 & 16794 & 223 & 36.5 & 1636 & 364 & ALONSO-ALVAREZ et al., 2002 \\
3.19 & 322 & 239 & - & 126.8 & 317 & 2451 & - & ABDEL-SHAFY; HEGEMANN; \\
& & & & & & & & GULDNER, 1996 \\
\hline \hline
\end{tabular}

Fonte - Karvelas; Katsoyiannis; Samara (2003).

A produção do lodo de esgoto aumenta substancialmente com o desenvolvimento das instalações de tratamento de esgoto, o que faz com que a disposição apropriada desse lodo seja mais premente. A alta concentração de metais pesados no lodo é um dos mais 
importantes fatores de impacto ambiental (WILKINSON; HILL; HILLMAN, 2003; CHEN et al., 2005; LIU et al., 2005). Os efluentes de estações de tratamento de esgoto municipais podem conter concentrações de metais acima dos níveis permitidos, uma vez que a presença de metais no esgoto de entrada concentra-se no lodo, a disposição de lodo carregado de metais pesados representa um risco ao meio ambiente quando utilizado para agricultura ou em aterros (LAZZARI et al., 2000; SCANCAR et al., 2000; MANTOVI; BALDONI; TODERI, 2005). Se o lodo de esgoto, depois de tratado, poderá ser usado como fertilizante ou não depende da concentração de metais pesados nele contidos.

De acordo com os padrões ou limites estabelecidos pela SÃO PAULO - CETESB (2001) para metais pesados, em lodo de esgoto, os resultados desta investigação revelam que o lodo estava dentro dos limites aceitáveis. Mas, durante a revisão bibliográfica, observa-se a necessidade de as autoridades competentes, responsáveis pela legislação do lodo para uso agrícola no país, tomarem as providências necessárias o mais rápido possível, com maior rigor na legislação para com os metais: $\mathrm{Pb}$ e $\mathrm{Ni}$. Pois o $\mathrm{Pb}$ é classificado como microcontaminante ambiental e o $\mathrm{Ni}$ como elemento essencial e simultaneamente microcontaminante. E a necessidade de incluir na legislação em vigor limites de tolerância para o Cr, sendo que esse é classificado como elemento essencial, mas simultaneamente microcontaminante (CAMPOS, 2005).

A prática de utilização do lodo de esgoto como adubo constitui potencial fonte de contaminação de solo e, conseqüentemente, incorporação de metais na cadeia alimentar, podendo persistir no solo por longos períodos. Perdas por adsorção, remoção pelas plantas cultivadas ou lixiviação são normalmente baixas. Assim, solos poluídos com metais podem constituir fonte de contaminação para plantas e animais durante um longo tempo. A ubiquidade de certos metais em decorrência de seu transporte atmosférico é um fato, porém, quando comparada à elevação das concentrações de metais de determinada região pela 
utilização de lodo de esgoto na agricultura torna-se irrelevante (CHASIN; CARDOSO, 2003).

A verificação da acumulação de metais pesados no solo e nas plantas adubadas com o biossólido também poderia ser realizada para garantir a boa qualidade, tanto do biossólido quanto do produto por ele adubado.

A Companhia de Saneamento Básico do Estado do Paraná (SANEPAR) realizou estudos da toxicidade da adição de níquel em quantidades elevadas no solo e chegaram à conclusão que, dependendo do tipo de solo, a absorção do metal pelo solo era mínima, variando entre 1 e 5\%, e, ainda, que a adição em conjunto com esterco reduz ainda mais a presença de Ni. As formas orgânicas e carbonatos de Ni podem sofrer ou não alterações em suas concentrações, dependendo do tipo de solo (PARANÁ - SANEPAR, 1999).

Ainda, no estudo, constata-se que a fração da forma disponível de Zn foi menor que $10 \%$ do metal adicionado em vários tipos de solo e que diminui com adição conjunta de esterco, mostrando a sua afinidade com a matéria orgânica do solo. Para a maioria das doses de Zn, a concentração da forma de carbonato foi ligeiramente superior à disponível nos solos e a adição de esterco aumentou essa forma de Zn.

Numerosas são as fontes de cádmio nos efluentes e lodos de esgoto, incluindo as excretas humanas, a corrosão de tubulações de cobre galvanizadas que compõem redes hidráulicas domésticas, o descarte inadequado de baterias de $\mathrm{Ni}-\mathrm{Cd}$ e a adição direta decorrente de processos industriais. Assim, o uso desse material na agricultura, como método de disposição de resíduos sólidos, deve ser avaliado diante de seu potencial tóxico (CHASIN; CARDOSO, 2003).

Outra principal fonte de contaminação na agricultura pelo lodo de esgoto é pelo zinco. Nesse tipo de matriz, o zinco encontra-se em concentrações 100 a 200 vezes superiores à de cádmio. Entretanto, acredita-se que esse fato possa servir como proteção à cadeia alimentar, uma vez que o zinco antagoniza a absorção do cádmio pela planta, causando, 
portanto, fitotoxicidade para o vegetal antes que o cádmio se acumule na planta em quantidades elevadas (BERTON, 2000).

Foram analisados zinco na bacia do Rio Sapucaí-Mirim, na região nordeste do Estado de São Paulo, onde há predominância de indústrias de couro, de borracha, calçadistas e fundição, foram detectados níveis máximos de zinco nas águas de 0,033 ug/mL. Entretanto, em algumas frações móveis de sedimentos, os níveis atingiram concentrações de até 1024 ug/g de sedimento (AVELAR; ROMA; LONGO, 1997).

Outro importante metal é o mercúrio proveniente de várias fontes e que está presente no lixo urbano. Isso pode contaminar o composto orgânico, produto da reciclagem da parte orgânica do lixo, e o chorume, líquido gerado no lixo e que é lançado em corpos receptores (rios) ou penetra no solo alcançando águas subterrâneas (TEVES, 2001). Agrava-se tal situação nos períodos de crise de energia hidrelétrica, quando, normalmente, ocorre a substituição de lâmpadas tradicionais (incandescentes) pelas fluorescentes, que consomem menos energia. Essas lâmpadas, ao se romperem, liberam de 20 a $30 \mathrm{mg}$ a forma de vapor de mercúrio. Há diversas marcas de baixa qualidade disponíveis no mercado que queimam e quebram com facilidade, significando aumento do risco de exposição (RODRIGUES; SILVA, 2001).

Não há dúvidas de que o lodo de esgoto manejado e monitorado de forma adequada é um excelente fertilizante orgânico, pois poderá enriquecer o solo e aumentar a produção agrícola, levando a inúmeros fatores positivos como: diminuição da carga orgânica e microbiológica, lançada nos corpos hídricos e no meio ambiente, reduzindo a necessidade de fertilizantes artificiais, com a conseqüente diminuição de gastos em energia, e da contaminação industrial, possibilitando maior conservação do solo pelo seu enriquecimento com matéria orgânica, o que pode proporcionar melhorias na sua estrutura e com isso minimizar a erosão; diminuição das enfermidades; gerando empregos para construção, 
operação e manutenção das ETEs e melhoria na paisagem e nas áreas de lazer, devido à retirada dos esgotos do meio ambiente (MALTA, 2001).

Este estudo revela a importância da implantação de estação de tratamento para o tratamento dos esgotos que possam causar impactos ambientais nos corpos de água que irão receber esses efluentes. Sendo assim, faz-se necessário verificar variações de $\mathrm{pH}$, temperatura, pluviosidade e presença de compostos tóxicos que podem causar variações abruptas e, com isso, interferir no desempenho da ETE, possibilitando adequações convenientes, garantindo efluentes de qualidade (SILVA et al., 2004).

Nesta pesquisa foi possível alcançar os objetivos traçados inicialmente, sendo caracterizados os níveis de $\mathrm{Cd}, \mathrm{Cr}, \mathrm{Cu}, \mathrm{Hg}, \mathrm{Mn}, \mathrm{Pb}$ e $\mathrm{Zn}$ no esgoto não tratado e tratado, assim como os níveis de $\mathrm{As}, \mathrm{Be}, \mathrm{Cd}, \mathrm{Cr}, \mathrm{Cu}, \mathrm{Fe}, \mathrm{Hg}, \mathrm{Mn}, \mathrm{Ni}, \mathrm{Pb}, \mathrm{St}, \mathrm{TI}, \mathrm{V}$ e $\mathrm{Zn}$ no lodo formado na ETE-Ribeirão Preto, implantada em 2002. Até o presente momento essa estação trata aproximadamente a metade do esgoto gerado no município, porém, as autoridades têm como objetivo tratar, futuramente, $100 \%$ do esgoto gerado em Ribeirão Preto-SP e, diante dessa perspectiva, subtende-se que é necessário continuar as pesquisas nessa área, fazendo novos monitoramentos juntamente com o crescimento da ETE-Ribeirão Preto.

Durante o desenvolvimento deste estudo foi possível aprofundar o conhecimento sobre a problemática da condição de coleta e tratamento de esgoto nas regiões brasileiras, que se apresenta deficiente, ficando evidenciado que esta temática precisa ser mais valorizada, considerando o significado social da implantação de adequados sistemas de coleta e de tratamento de esgoto para a população, não só brasileira, mas de qualquer região do mundo. 
5 CONCLUSÕES 


\section{CONCLUSÕES}

Com esta pesquisa foi possível atingir os objetivos propostos inicialmente e, assim, verificar e avaliar as concentrações de metais presentes no esgoto não tratado, tratado e no lodo da estação de tratamento de Ribeirão Preto-SP.

A partir dos resultados concluiu-se que:

- a ETE-Ribeirão Preto se caracteriza como um sistema de tratamento por lodos ativados que apresenta uma importante remoção de metais pesados nos efluentes, quando comparados com os dados apresentados na literatura, sendo essa remoção de 60,0\% para o $\mathrm{Cd} ; 16,4 \%$ para o $\mathrm{Cr} ; 44,2 \%$ para o $\mathrm{Cu}$; $\mathrm{Mn}: 10,5 \%, \mathrm{Hg}: 61,5 \%, \mathrm{~Pb}$ : $39,7 \%$ e $\mathrm{Zn}: 44,9 \%$

- as concentrações médias de metais no esgoto tratado da ETE-Ribeirão Preto encontram-se abaixo dos limites permitidos pelo CONAMA, Resolução n ${ }^{0} 357$, de 17 de março de 2005, que estabelece as condições e padrões de lançamento de efluentes. O efluente tratado na ETE-Ribeirão Preto é lançado no córrego Ribeirão Preto, pelo Decreto $\mathrm{n}^{0} 10.755$, de 22/11/77, da CETESB, e classifica o córrego Ribeirão Preto como pertencente à Classe 4. Os níveis médios de $\mathrm{Cd}, \mathrm{Cr}, \mathrm{Cu}, \mathrm{Hg}, \mathrm{Mn}, \mathrm{Pb}$ e $\mathrm{Zn}$ analisados estão dentro dos níveis máximos permitidos pelos padrões de qualidade de água Classe 4 da CETESB 10.755/77;

- as concentrações dos metais no lodo As, $\mathrm{Be}, \mathrm{Cd}, \mathrm{Cr}, \mathrm{Cu}, \mathrm{Fe}, \mathrm{Hg}, \mathrm{Mn}, \mathrm{Ni}, \mathrm{Pb}, \mathrm{St}, \mathrm{TI}, \mathrm{V}$ e Zn em mg/kg estão dentro dos níveis máximos permitidos pela legislação e/ou órgãos técnicos brasileiros e previamente estabelecidos pela Companhia de Tecnologia de Saneamento Ambiental de São Paulo, para o lodo destinado à agricultura (SÃO PAULO. CETESB, 2001). Esses valores estão, também, de acordo com as normas internacionais, como: legislações européias (EUROPEAN. Council 
Directive 86/278/EEC), norte-americanas (USEPA) e também próximos de várias legislações de outros países desenvolvidos;

- os resultados obtidos no trabalho confirmam a qualidade do lodo gerado pela ETERibeirão Preto, podendo ser utilizado na agricultura. Porém, torna-se necessário um monitoramento contínuo como medida fundamental para assegurar a qualidade dos efluentes e dos lodos.

Considerando a importância do adequado gerenciamento dos esgotos na ETERibeirão Preto como fator determinante para a saúde pública, no que se refere à presença de metais, o presente estudo traz informações para o município de Ribeirão Preto, assim como para as autoridades político-administrativas municipais. As informações também direcionam à articulação interdisciplinar e intersetorial no âmbito municipal ambiental, favorecendo uma relação com a saúde humana e, conseqüentemente, com a qualidade de vida. 
6 CONSIDERAÇÕES FINAIS 


\section{CONSIDERAÇÕES FINAIS}

A avaliação de metais em estações de tratamento permite verificar se existem riscos de contaminação no meio ambiente por esses elementos e, conseqüentemente, exposição da população, dada a importância do tratamento de esgoto para a prevenção de doenças. Considerando os fatores custo-benefício à saúde de todos, deve-se deflagrar um processo de discussão com a comunidade, órgãos públicos e de meio ambiente.

Considera-se o tratamento de esgoto uma temática nova em que há muito a ser investido, avaliado e monitorado, razão pela qual, no estudo apresentado, sugere-se os seguintes trabalhos, para dar continuidade a essa linha de pesquisa, no município de Ribeirão Preto:

- análise de metais no córrego Ribeirão Preto-SP e no rio Pardo, para quantificar se os níveis estão de acordo com as condições e padrões de lançamento de efluentes no corpo receptor, segundo as respectivas classificações desses corpos de água;

- implantar uma horta, com espécies vegetais, utilizando como adubo o lodo formado pela ETE-Riberão Preto, e analisando os níveis de metais no vegetal e no solo adubado. O lodo, após a disposição no solo, entra no ecossistema não só do solo, mas também das plantas, aqüíferos subterrâneos e animais de pequeno e grande porte que se alimentam de gramíneas, enfim, adentram a cadeia alimentar do homem, sendo perigoso do ponto de vista da Saúde Pública.

A ampliação do conhecimento no contexto do gerenciamento do esgoto no Brasil, com pesquisas como as referidas anteriormente, torna-se necessário considerando a situação atual no país. Nas regiões brasileiras, $47,8 \%$ dos municípios não têm coleta de esgoto, sendo seus principais receptores os rios e oceanos, do restante $52,2 \%$ que possuem coleta de esgoto, apenas 20,2\% têm tratamento (IBGE, 2002). 
Esse conhecimento também precisa ser aprofundado, considerando a realidade internacional. A América Latina é uma das regiões com maior concentração da população em áreas urbanas, que corresponde a mais de 360 milhões de habitantes. A cobertura média de tratamento de esgoto é de 14\% (CEPIS, 2002). Existem mais de 500.000 ha de cultivos regados com águas residuárias, em sua maior parte sem tratamento, o que implica em alto risco de enfermidades entéricas.

Sem dúvida, a Promoção da Saúde propicia a melhoria das condições de bemestar, por meio do desenvolvimento de atitudes e implementação de estratégias, que permitam à população um maior controle sobre sua saúde, fato que nos desperta grande interesse, enquanto profissionais da área de saúde pública. 
REFERÊNCIAS 


\section{REFERÊNCIAS*}

ABDEL-SHAFY, H.; HEGEMANN, W.; GULDNER, C. Fate of heavy metals via chemicalbiological upgrading of sewage sludge treatment plants. Environ. Manage. Health, v. 713, p. 28-36, 1996.

ABU-HILALAH; BRADAN, M. M. Effect of pollution sources on metal concentrations in sediment cores from the Gulf of Aqaba (Red Sea). Marine Poll. Bull., v. 21, n. 4, p. 190-197, 1990.

ALONSO-ALVAREZ, E.; CALLEJÓN, M.; JIMÉNEZ, J.; TERNERO, M. Heavy metal extractable forms in sludge from wastewater treatment plants. Chemosphere, v. 47, p.765$775,2002$.

AMERICAN PUBLIC HEALTH ASSOCIATION. APHA.. Standard methods for the examination of water and wastewater. 20. ed. Washington DC: APHA INC. 1015, 1998. $1085 \mathrm{p}$

ANDREOLI, C. V.; LARA, A. I.; FERREIRA, A. C.; BONNET, B. R. P.; PEGORINI, E. S. A gestão dos biossólidos gerados em estações de tratamento de esgoto doméstico.

Engenharia e Construção, Curitiba, n. 24, p.18-22, 1998.

ANGELIDIS, M.; GIBBS, R. J. Chemistry of metals in anaerobically treated sludges. Water Res., v. 23, p. 29-33, 1989.

ARFSTEN, D. P.; AYLWARD, L. L.; KARCH, N. J. Chromium. In: ZELIKOFF, J. T.; THOMAS, P. T. Immunotoxicology of environmental and occupational metals. London: Taylor \& Francis, 1998. p. 63-92.

ASSOCIAÇÃO NACIONAL DOS SERVIÇOS MUNICIPAIS DE SANEAMENTO. (ASSEMAE). Informativo da Associação Nacional dos Serviços Municipais de Saneamento. No117- maio/junho.Disponível em: http://www.assemae.org.br. Acesso em: 22 dez. 2005.

AVELAR, W. E. P.; ROMA, F.; LONGO, L. L. Poluição por metais pesados na bacia do rio Sapucaí-Mirim (Nordeste do Estado de São Paulo, Brasil), pela indústria de couro. Arq. Biol. Technol., v. 40, n.1, p.205-212, 1997.

*Normatizado de acordo com: ASSOCIAÇÃO BRASILEIRA DE NORMAS TÉCNICAS. NBR 6023 - Informação e documentação. Referências: elaboração. Rio de Janeiro: ABNT, ago.2002 e NBR 14724- Informação e documentação. Trabalhos acadêmicos: apresentação. Rio de Janeiro: ABNT, ago.2002. 
AZEVEDO, F. A.; NASCIMENTO, E. S.; CHASIN, A. A. M. Mercúrio. In: AZEVEDO, F. A.; CHASIN, A. A. M. Metais: gerenciamento de toxicidade. São Paulo: Atheneu, 2003. Cap.11, p. 299-352.

AZEVEDO NETTO, J. M. Cronologia do abastecimento de água (até 1970). Rev. DAE, v. 44, n.137, p.106-111, jun. 1984.

BANCO MUNDIAL. A agenda ambiental marrom - volume 1: Relatório de Política Brasil: gestão dos problemas da poluição. Brasília: BM, 1998.

BARALIKIEWICS, D.; SIEPAK, J. Slurry sampling for electrothermal atomic absorption spectrometric determination chromium, nickel, lead, and cadmium in sewage sludge. Anal. Chim. Acta, v. 437, p.11-16, 2001.

BARCELOUX, D.G. Copper. Clin. Toxicol., v. 37, n. 2, p. 217-230, 1999a.

Manganese. Clin. Toxicol., v. 37, n. 2, p.293-307, 1999b.

BARTH, E. F.; ETTINGER, M. B.; SALOTTO, B. V.; MCDERMOTT, G. N. Summary report on the effects of heavy metals on the biological treatment process. J. Water Pollut. Control Fed., v. 37, p.86-96, 1965.

BERTAZZOLI, R.; PELEGRINI, R. Descoloração e degradação de poluentes orgânicos em soluções aquosas através do processo fotoeletroquímico. Rev. Quím. Nova, v. 25, n.3, p.470476, maio 2002.

BERTON, R. S. Riscos de contaminação do agroecossistema com metais pesados. In: BETTIOL, W.; CAMARGO, O. A. (Eds.). Impacto ambiental do uso agrícola do lodo de esgoto. Jaguariúna: Embrapa, 2000. p. 259-268.

BETTIOL, W.; CAMARGO, O. A. Impacto ambiental do uso agrícola do lodo de esgoto. Embrapa: Jaguariúna, 2000. 312p.

BINDER, S.; FORNEY, D.; KAYE, W.; PASCHAL, D. Arsenic exposure in children living near a former copper smelter. Bull. Environ. Contam. Toxicol., v. 39, p. 114-121, 1987. 
BODZEK, D.; JANOSZKA, B.; DOBOSZ, C.; WARZECHA, L.; BODZEK, M. Determination of polycyclic aromatic compounds and heavy metals in sludges from biological sewage treatment plants. J. Chromatogr., v. A774, p.177-192, 1997.

BOMBIG, J. A. Suposto dono de Omega venceu licitação em Ribeirão sob Palloci. Folha Brasil, Ribeirão Preto, 01 novembro de 2005. Caderno A, p. 6.

BRAGATO, G.; LEITA, L.; FIGLIOLIA, A.; DE NOBILI, M. Effects of sewage sludge pretreatment on microbial biomass bioavailability of heavy metal. Soil Till. Res., v. 46, p.129134, 1998.

BRASIL. CONFERÊNCIA NACIONAL DE SANEAMENTO. CNS. Comissão de Desenvolvimento Urbano e Interior da Câmara Federal - Subcomissão de Saneamento. Relatório síntese da Conferência Nacional de Saneamento. Brasília (DF): CNS, 1999.

BRASIL. CONSELHO NACIONAL DO MEIO AMBIENTE. CONAMA. Resolução N²0, de 18 de junho de 1986. Classifica ção das águas doces, salobras e salinas do Território Nacional. Disponível em : www.lei.adv.br/conama.01.htm. Acesso em: 22 dez 2005.

. Resolução No. 357 de 17 de Março de 2005. Dispõe sobre a classificação dos corpos de água e diretrizes ambientais para o seu enquadramento, bem como estabelece as condições e padrões de lançamento de efluentes, e dá outras providências. Diário Oficial da União, Brasília, 2005. Disponível em:http://www.in.gov.br/. Acesso em: 18 ago. 2005.

BRASIL. Leis, Decretos. Senado Federal. PLS 266 de 05 de dezembro de 1996. Disponível em: http:// www.legis.senado.gov.br. Acesso: em 22 jul. 2002.

Mensagem no 04. Veta o Projeto de Lei 199 de 1993 que Dispõe sobre a Política Nacional de Saneamento, seus instrumentos e dá outras previdências. D.O.U. - Diário Oficial da República Federativa, Brasília, 05 jan. 1995. Seção I, p. 274.

BRASIL. Ministério das Cidades. Sistema Nacional de Informações em Saneamento. SNIS. Diagnóstico nacional dos serviços de água e esgoto. Brasília (DF): SEDU/IPEA. Disponível em: http://www.snis.gov.br. Acesso em 2002 e 2003.

BRASIL. Ministério do Planejamento e Orçamento. MPO. Secretaria de política urbana. Série modernização do setor saneamento. Diagnóstico do setor; saneamento: estudo econômico e financeiro. Brasília (DF): MPO, 1995. v. 7. 
BRASIL. Ministério da Saúde. DATASUS. Banco de dados do Sistema Único de Saúde. Informações de saúde- Indicadores de saúde. 2000. Disponível em: www.datasus.gov.br. Acesso em: 22 dez. 2005.

. Fundação Nacional de Saúde - FUNASA. Associação Nacional dos Serviços Municipais de Saneamento - ASSEMAE. Diagnóstico nacional dos serviços municipais de saneamento. $2^{\mathrm{a} e d}$. Brasília: MS., 1996.

- Ministério da Saúde. Monografias uso agropecuário e domissanitário: portarias e resoluções do Ministério da Saúde. São Paulo: ILSI, 2000. 850p.

BROWN, H. G.; HENSLEY, C. P.; MCKINNEY, G. L.; ROBINSON, J. L. Efficiency of heavy metals removal in municipal sewage treatment plants. Environ. Lett., v. 5, p.103-114, 1973.

BROWN, M. J.; LESTER, J. N. Metal removal in activated sludge: the role of bacterial extracellular polymers. Water Res., v.13, p.817-837, 1979.

BUDAVANI, S. The merck index. 12 ed. New Jersey: Merck \& CO, 1996. p. 1732-1734.

CÂMARA, V.M. Epidemiologia e ambiente. In: MEDRONHO, R.A. et al. Epidemiologia. São Paulo: Atheneu, 2003. cap. 25, p.371-384.

CAMPOS, M. J. A. Instituto de Química. UNESP - Araraquara-SP. Elementos. Disponível em: http://www.mundoquímico.hpg.ig.com.br/metais_pesados_e_seus efeitos. Acesso em: 22 ago. 2005.

CARAPELLA, S. C. Arsenic and arsenic alloys. In: KROSCHWITZ, J. I., HOWE-GRANT, M. (Ed). Kirk-othmer encyclopedia of chemical technology. New York: John Wiley, 1992. v. 3, p. 624-633.

CARVALHO, A. I. Da saúde pública às políticas saudáveis: saúde e cidadania na pós modernidade. Ci. Saúde Coletiva, Rio de Janeiro, v. 1, n. 1, p. 104-121, 1996.

CAUSON, R. Validation of chromatographic methods in biomedical analysis. Viewpoint and discussion. J. Chromatogr. B., v. 689, p. 175-180, 1997. 
CELERE, M. S.; OLIVEIRA, A. S.; TREVILATO, T. M. B.; SEGURA-MUÑOZ, S.I. Análise de metais no chorume coletado no módulo I e II do aterro sanitário de Ribeirão Preto, S.P. In: SEMINÁRIO INTERNACIONAL DE INICIAÇÃO CIENTÍFICA DA UNIVERSIDADE DE SÃO PAULO (SIICUSP), 13, Ribeirão Preto, 11 de novembro de 2005. Anais. Ribeirão Preto: USP, 2005.

CENTRO PANAMERICANO DE INGENIERÍA SANITARIA Y CIENCIAS DEL AMBIENTE. CEPIS. División de Salud y Ambiente. Sistemas Integrados de Tratamiento y Uso de Aguas Residuales en America Latina: realidad y potencial. Resumen ejecutivo. Lima, 2002. Disponível em: http://www.cepis.ops-oms.org/bvsaar/e/proyecto/proyectoeco.htm. Acesso em: 02 nov. 2005.

CHAGAS, W. F. Estudo de patógenos e metais em lodo digerido bruto e higienizado para fins agrícolas, das estações de tratamento de esgotos da Ilha do Governador e da Penha no Estado do Rio de Janeiro. 2000. 89 f. Dissertação (Mestrado em Saúde Pública) Programa da Fundação Oswaldo Cruz. Escola Nacional de Saúde Pública, Rio de Janeiro, 2000 .

CHASIN, A. A. M.; CARDOSO, L. M. N. Cádmio. In: AZEVEDO, F. A.; CHASIN, A. A. M. Metais: gerenciamento de toxicidade. São Paulo: Atheneu, 2003. Cap.10, p. 265-297.

CHEN, Y. C.; HUA, Y. M.; ZHANG, S. H.; TIAN, G. M. Transformation of heavy metal forms during sewage sludge bioleaching. J. Hazard Mater., 2005. In press.

CHENG, M. H.; PATTERSON, E. R.; MINEAR, R. A. Heavy metals uptake by activated sludge. J. Water Pollut. Control Fed., v. 47, p.362-376, 1975.

CHIPASA, K. B. Accumulation and fate of selected heavy metals in a biological wastewater treatment system. Waste Manage., v. 23, p. 135-143, 2003.

CLARK, E.G.; LEAVELL, H.R. Níveis de aplicação da medicina preventiva. In: LEAVELL, H.R.; CLARK, E.G. Medicina preventiva. São Paulo: Mcgraw-Hill do Brasil Ltda, 1977. p.11-36.

CORNU, S.; NEAL, C.; AMBROSI, J.; WHITEHEAD, P.; NEAL, M.; SIGOLO, J.; VACHIER, P. The environmental impact of heavy metals from sewage sludge in ferralsols (São Paulo, Brazil). Sci. Total Environ., v. 271, p.27-48, 2001.

COSTA, M. Carcinogenic metals. Science Progress., v. 81, n. 4, p. 329-339, 1998. 
DAMASCENO, S. Remoção de metais pesados em sistemas de tratamento de esgotos sanitários por processo de lodos ativados e por um reator compartimentado anaeróbio. 1996. 141 f. Dissertação (Hidráulica e Saneamento) - Escola de Engenharia de São Carlos, Universidade de São Paulo, São Carlos, 1996.

DENILON, R.; SILBERGELD, E. Risk of municipal solid waste incineration an environmental perspective. Risk Analysis, v. 8, n. 3, p. 343-355, 1988.

EMPRESA BRASILEIRA DE PESQUISA AGROPECUÁRIA. EMBRAPA. Centro Nacional de Pesquisa de Solos. Manual de métodos de análise de solo. 2.ed. Rio de Janeiro: EMBRAPA, 2000. 212 p.

EUROPEAN. Council Directive 86/278 EEC on the protection of the environment, and in particular of the soil, whem sewage sludge is used in agriculture, O.J. No.L181, 04/07/1986, p.6

GANONG, W. F. Fisilogia médica. 14. ed. Rio de Janeiro: Prentice Hall do Brasil, 1993. p. 342-343.

GOYER, R. A. Toxic effects of metals. In: AMDUR, M. O.; DOUL,L.; KLAASSEN, C. D. (Eds). Casarett and doull's toxicology: the basic science of poisons. $4^{\text {th. }}$ ed. New York: McGraw-Hill, 1996. p. 691-736.

GRISOTTO, L. E. G.; PHILIPPI JR., A. A questão dos recursos hídricos. In: ROMÉRO, M. A.; PHILIPPI JR., A.; BRUNA, G. C. Panorama ambiental da metrópole de São Paulo. São Paulo: Signus, 2004. p. 16-19.

GROSSI, M. G. L. Avaliação da qualidade dos produtos obtidos de usinas de compostagem brasileiras de lixo doméstico através de determinação de metais pesados e substâncias orgânicas tóxicas. 1993. Tese (Doutorado em Química) - Instituto de Química da USP, Universidade de São Paulo. São Paulo, 1993.

HARADA, M.; NAKANISHI, J.; KONUMA, S.; OHNO, K.; KIMURA, T.; YAMAGUCHI, H.; TSURUTA, K.; KIZAKI, T.; OOKAWARA, T.; OHNO, H. The present mercury contents of scalp hair and clinical symptons in inhabitants of the Minamata area. Environ. Res., v. 77, n. 2, p. 160-164, 1999.

HAZARD MANAGEMENT. HAZARDTEXT. Iron. In: TOMES CPS TM SYSTEM. Toxicology, occupational medicine and environmental series. Englewood: Micromedex, 2000. CD-ROM. 
HAZARDOUS SUBSTANCES DATA BANK. HSDB. Copper. In: TOMES CPS TM SYSTEM. Toxicology, occupational medicine and environmental series. Englewood: Micromedex, 2000. CD-ROM.

. Mercury. In: In: TOMES CPS ${ }^{\mathrm{TM}}$ SYSTEM. Toxicology, occupational medicine and environmental series. Englewood: Micromedex, 2000. CD-ROM.

HILLMAN, R. S. Hematopoeitic agents: growth factors, minerals and vitamins. In: HARDMAN, J. G.; LIMBIRD, L. E. (Eds.) Goodman and Gilman's the pharmacological basis of therapeutics. $9^{\text {th }}$.ed. New York: McGraw Hill, 1995. p.1317-1325.

HUBERMAN, L. História da riqueza do homem. 10 ed. Rio de Janeiro: Zahar, 1974.

HUNT, K.; BROWN, D.; GADDIS, L.; RATZKI, T. When your back is against the ceiling: Springfield Ohio works towards compliance with the 40 CFR 503 regulations. In: The management of water and wastewater solids for the $21^{\text {st }}$ century: a global perspective, jun. 1994. Washington (D.C.): Water Environment Federation, 1994. p. 14-39.

INSTITUTO BRASILEIRO DE GEOGRAFIA E ESTATÍSTICA. IBGE. Pesquisa Nacional de Saneamento Básico. PNSB. Disponível em: http//www.ibge.gov.br Acesso em: 01 nov. 2002.

INSTITUTO PARA A DEMOCRATIZAÇÃO DE INFORMAÇÕES SOBRE SANEAMENTO BÁSICO E MEIO AMBIENTE. WEB-RESOL. Glossário. Disponível em: http://www.resol.com.br. Acesso em: 05 dez. 2005.

INTERNATIONAL LABOUR ORGANIZATION. ILO. Encyclopedia of occupational health and safety. Metals: chemical properties and toxicity. $4^{\text {th }}$ ed. Geneve: ILO, 1997. v. 3, p. 63.1-63.8, 1997.

IREGREN, A. Manganese neurotoxicity in industrial exposure. Proof of effects, critical exposure level and sensitive test. Neurotoxicology, v. 20, n. 2-3, p. 315-323, 1999.

JACOBI, P. Habitat e saúde na periferia. Rev. São Paulo em Perspectiva, São Paulo, v. 4, n. 3/4, p. 121-130, 1990.

JORDÃO, E. P.; PESSOA, C. A. Tratamento de esgotos domésticos. Rio de Janeiro: Associação Brasileira de Emgenharia Sanitária - ABES, 1995. 681p. 
JORDÃO, P. C.; COSTA, E. D.; BRUNE, W.; GOULART, A. T. Química Nova, v.16, n .6, 1993.

JORGE, W. E. A política nacional de saneamento pós-64. 1987. Tese (Doutorado) Faculdade de Arquitetura e Urbanismo, Universidade de São Paulo, São Paulo, 1987.

KARVELAS, M.; KATSOYIANNIS, A.; SAMARA, C. Occurrence and fate of heavy metals in the wastewater treatment process. Chemosphere, v. 53, p.1201-1210, 2003.

KELLEY, C. Cadmium therapeutic agents. Curr. Pharm. Des., v. 5, n. 4, p. 229-240, 1999.

KREISS, I. Cadmium contamination of the countryside, a case study on health effects. Toxicol. Ind. Health, v. 6, n. 5, p.181-188, 1990.

KROSCHWITZ, J. I. (Ed.). Kirk-othmer encyclopedia of chemical technology. New York: John Wiley, 1995. v. 14.

LAI, J. C.; MINSKI, M. J.; CHAN, A. W.; LEUNG, T. K.; LIM, L. Manganese mineral interactions in brain. Neuro Toxicol., v. 20, n. 2-3, p. 433-444, 1999.

LAKATOS, E.M.; BRUTSCHER, S.M. O conceito saúde-doença analisado através dos tempos e a prática previdenciária no Brasil. Saúde em Debate, Rio de Janeiro, v.24, n.54, p.75-89, jan/abr 2000.

LAZZARI, L.; SPERNI; L., BERTIN, P.; PAVONI, B. Correlation between inorganic (heavy metals) and organic (PCBs and PAHs) micropollutant concentrations during sewage sludge composting processes. Chemosphere, v. 41, p. 427-435, 2000.

LIU, W.H., ZHAO, J.Z., OUYANG, Z.Y., SODERLUND, L., LIU, G.H. Impacts of sewage irrigation on heavy metal distribution and contamination in Beijing, China. Environ. Int., v.31, p.805-812, 2005.

MADONI, P.; DAVOLI, D.; GUGLIELMI, L. Response of SOUR and AUR to heavy metal contamination in activated sludge. Water Res., v. 33, n. 10, p. 2459-2464, 1999.

MAGOSSI, L.; BONACELLA, P. Poluição das águas. São Paulo: Moderna, 1991. 
MALTA, T. S. Aplicação de lodos de estações de tratamento de esgotos na agricultura: Estudo do caso do Município de Rio das Ostras-RJ. 2001. 67 f. Dissertação (Mestrado em Engenharia Sanitária e Saúde Pública) - Fundação Oswaldo Cruz, Escola Nacional de Saúde Pública, Rio de Janeiro, 2001.

MANTOVI, P.; BALDONI, G.; TODERI. G. Reuse of liquid, dewatered, and composted sewage sludge on agricultural land: effects of long-term application on soil and crop. Water Res., v. 39, p. 289-296, 2005.

MARTINS, I. Manganês. In: AZEVEDO, F. A.; CHASIN, A. A. M. Metais: gerenciamento de toxicidade. São Paulo: Atheneu, 2003. Cap.3, p. 67-97.

MATSCHULLAT, J. Arsenic in the geosphere: a review. Sci.Total Environ., v. 249, p. 297$312,2000$.

MATTIAZO-PREZOTTO, E.; GLÓRIA, N. A. Uso de resíduos na agricultura. Piracicaba: ESALQ, 2000. mimeo.

MENDES, R. Aspectos históricos da patologia do trabalho. In: Patologia do trabalho. Rio de Janeiro: Atheneu, 1995.

MERCK, 2002. Disponível em: http://www.merck.com.br/quimica/pie/cd_fr.htm Acesso: 10 ago. 2002.

METCALF, L.; EDDY, H. P. Trataimento y depuración de las águas residuales. Tradução de Wastewater Engineering: collection, treatment and disposal. Barcelona (Espanha): Labor, 1977. p. 837 .

MIGUEL, A. R.; BEVIlACQUA, N.; GUERRA, P. A. D. V.; BAPTISTELli, S. C. Tratamento de águas residuárias domésticas. In: ROMÉRO, M. A.; PHILIPPI JR., A.; BRUNA, G. C. Panorama ambiental da metrópole de São Paulo. São Paulo: Signus, 2004. p. 77-87, 96-103.

MORAES, D. S. L.; JORDÃO, B. Q. Degradação de recursos e seus efeitos sobre a saúde humana. Rev. Saúde Pública, v..36, n. 3, p.370-374, 2002.

MOTTA, S. Saneamento. In: Rouquayrol, M.Z. Epidemiologia \& Saúde. 4.ed. Rio de Janeiro: MEDS, 1993, Cap.12, p.343-364. 
MUSHAK, P. Metabolism and system toxicity of nickel. In: NRIAGU, J. O. Nickel in the environment. New York: Wiley, 1980. p. 499-523.

NEUFELD, R. D.; HERMANN, E. R. Heavy metal removal by acclimated sludge. Water Pollut. Control Fed., v. 47, p. 310-329, 1975.

NOGUCHI, H.; ITO, H. Long-term experiment of applying sludge fertilizer to agricultural land. J. Inst. Water Environ. Manag., v. 6, n. 5, p. 576-582, 1992.

NRIAGU, J.O. Global cycle properties of nickel. In: NRIAGU JO, ed. Nickel in the environment. New York: John Wiley and Sons, p.1-26. 1980. Apud: WORLD HEALTH ORGANIZATION - Nickel. Geneva, p.383. [Environmental Health Criteria $n^{\circ}{ }^{\circ} 108$ ], 1991.

OGERA, R.C.; PHILIPPI JR., A. Estudo comparativo da gestão municipal estadual de serviços de água e esgoto. In: ROMÉRO, M. A.; PHILIPPI JR., A.; BRUNA, G. C. Panorama ambiental da metrópole de São Paulo. São Paulo: Signus, 2004. p. 545-552.

OLIVEIRA, J. P. Níquel. In: AZEVEDO, F. A.; CHASIN, A. A. M. Metais: gerenciamento de toxicidade. São Paulo: Atheneu, 2003. Cap. 5, p.127-142.

OLIVER, B. G.; COSGROVE, E. G. The efficiency of heavy metal removal by a conventional activated sludge treatment plant. Water Res., v. 8, p.869-874, 1974.

ORGANIZAÇÃO DAS NAÇÕES UNIDAS. ONU. Água doce 2003. Disponível em: http://www.wateryear2003.org. Acesso em: 24 jan. 2003.

ORGANIZATION FOR ECONOMIC COOPERATION AND DEVELOPMENT. OECD. Risks reduction monograph $\mathbf{n}^{\mathbf{0}}$ 5: Cadmium. Paris, France: OECD Environment Directorate, 1994.

OUTWATER, A. B. Reuse of sludge and minon wastwater residuals. S.L.: Lewis Publishers, 1994. 179p.

PAL, P.; SAMII, A.; CALNE, D. Magnese neurotoxicity: a review of clinical features, imaging and pathology. Neurotoxicology, v. 20, n. 2-3, p. 227-238, 1999.

PARANÁ. Companhia de Saneamento do Paraná. SANEPAR. Manual técnico para utilização do lodo de esgoto no Paraná. ANDREOLI, C.V.; FERNANDES, F. SANEPAR, Curitiba, 1997. 96 p. 
- Companhia de Saneamento do Paraná. Valores limites de concentração de metais pesados em lodo de esgoto para reciclagem agrícola aplicação no solo do Paraná, 1999. Disponível em: http://www.sanepar.com.br . Disponível em: 03 nov. 2005.

PARMEGGIANI, L. (Ed.). Encyclopedia of occupational health and safety. 3ed. Geneva: International Labour Office, 1983. v. 2, p. 1200-1209.

PATTERSON, J. W.; KODULULA, P. S. Metals distributions in activated sludge systems. J. Water Pollut. Control Fed., v. 56, n. 5, p. 432-441, 1984.

PEDrozO, M. F. M. Cobre. In: AZEVEDO, F. A.; CHASIN, A. A. M. Metais: gerenciamento de toxicidade. São Paulo: Atheneu, 2003. Cap.6, p.143-185.

PEIRANO, M. M. F. Remoção de metais pesados no tratamento biológico: sistema biológico tipo lodos ativados. Rev. Gerenciamento Ambiental, São Paulo, ano 5, n. 24, p. 51-53, março/abril 2002.

PEREZ, B.; FERNADEZ, A.; FERNADEZ, E.; FALQUE, E. Use of microwave single extractions for metal fractionation in sewage sludge. Anal. Chim. Acta, Espanha, v.431, p.209-218, 2001.

PETERS, K.; GAMMELGAARD, B.; MENNÉ, T. Nickel concentrations in fingernails as a measure of occupational exposure to nickel Contact Dermatitis. Copenhagen, v. 25, p. 237241, 1991.

PETRASEK, A. C.; KUGELMAN JR., I. J. Metals removals in conventional wastewater treatment plants. J. Water Pollut. Control Fed., v. 55, n. 9, p. 1183-1190, 1983.

PLANQUART, P.; BONIN, G.; PRONE, A.; MASSIANI, C. Distribution, movement, and plant availability of trace metals in soils amended with sewage sludge composts: application to low loadings. Sci. Total Environ., v. 241, p. 161-179, 1999.

RIBEIRÃO PRETO. Prefeitura Municipal. Departamento de Água e Esgoto de Ribeirão Preto. DAERP. Disponível em: www.daerp.ribeirãopreto.sp.gov.br. Acesso em: 05 abr. 2005.

RIBEIRÃO PRETO. Prefeitura Municipal. CODERP. Portal da cidade de Ribeirão Preto. Disponível em: http://www.coderp.com.br . Acesso em: 1 nov. 2005. 
ROCHA, M. M.; SARTI, H. L. C.; LIMA, L. F.; JUNIOR, O.C. A urbanização e a poluição dos recursos hídricos. O Mundo da Saúde, v. 28 , n. 4, p. 388-394, 2004.

RODRIGUES, K.; SILVA, L. W. Lâmpadas do apagão têm risco ambiental. Folha de S. Paulo, São Paulo, 19 de jun. 2001. Cotidiano, p..5.

ROUQUAYROL, M. Z.; ALMEIDA FILHO, N. Epidemiologia \& saúde. 5 ed. Rio de Janeiro: MEDSI, 1993. p. 538.

SAKUMA, A. M.; DE CAPITANI, E. M.; TIGLEA, P. Arsênio. In: AZEVEDO, F. A.; CHASIN, A. A. M. Metais: gerenciamento de toxicidade. São Paulo: Atheneu, 2003. Cap. 8, p.203-238.

SANTOS, H. F. Uso agrícola do lodo das estações de tratamento de esgotos sanitários (ETEs): subsídios para elaboração de uma norma brasileira. Dissertação (Mestrado) - Setor de Tecnologia em Saneamento Ambiental, Universidade Mackenzie, São Paulo, 1996.

SÃO PAULO. Decreto Estadual N. 8468. Aprova o regulamento da Lei n. 997, de 31 de maio de 1976, que dispõe sobre a prevenção e o controle da poluição do meio ambiente. Diário Oficial da União. 8 de set. de 1976.

Companhia de Tecnologia de Saneamento Ambiental. CETESB. Guia de coleta e preservação de amostras de água. São Paulo: CETESB, 1987.

. Norma CETESB P.4230. Ciência e Tecnologia à Serviço do Meio Ambiente. Aplicação de lodos de sistemas de tratamento biológico em áreas agrícolas. Critérios para projetos e operação: manual técnico. São Paulo: CETESB, 2001.

SÃO PAULO. Secretaria de Estado da Saúde. CBVA. Curso básico de vigilância ambiental em saúde. São Paulo: SES, março de 2001. p. 47.

SÃO PAULO. Secretaria de Energia, Recursos Hídricos e Saneamento. SABESP. Tratamento de Esgoto por Lodos Ativados. Disponível em: http://www.sabesp.com.br/sabesp-ensina/intermediário/lodos_Ativados/default.htm. Acesso em: 10 mar. 2005. 
SÃO PAULO. SECRETARIA DO MEIO AMBIENTE. CIÊNCIA E TECNOLOGIA À SERVIÇO DO MEIO AMBIENTE. CETESB. Tecnologias para tratamento de esgotos sanitários, $1988 . \quad$ SISTTRAT. $\quad$ Disponível em: http://www.flipper.ind.br/32\%20\%20TECNOLOGIAS\%20\%20PARA\%200\%20TRATAME TNO\%20DE\%20ESGOTO.htm. Acesso em: 02 mar. 2005.

SAWYER, C. N.; McCARTY, P. L. Chemistry for environmental engineering. Singapura: Mcgraw Hill, 1978. 532 p.

SCANCAR, J.; MILACIC, R.; STRAZAR, M.; BURICA, O. Total metal concentrations and partitioning of $\mathrm{Cd}, \mathrm{Cu}, \mathrm{Fe}, \mathrm{Ni}$ and $\mathrm{Zn}$ in sewage sludge. Sci. Total Environ., v. 250, p. 9-19, 2000 .

SCHALCH, V. Remoção de metais pesados em sistemas de tratamento de esgoto sanitário por processo de lodo ativado e por um reator compartimentado. 1984. $103 \mathrm{f}$. Dissertação (Mestrado em Hidráulica e Saneamento) - Escola de Engenharia de São Carlos, Universidade de São Paulo, São Carlos, 1984.

SCHUHMACHER, M.; AGRAMUNT, M. C.; BOCIO, A.; DOMINGO, J. L.; DE KOK, H. Annual variation in the levels of metals and PCDD/PCDFs in soil and herbage samples collected near a cement plant. Environ Int., v. 29, p. 415-421, 2002.

SEGURA-MUÑOZ, S.I. Distribuição especial e variação temporal de metais pesados na área de influência do aterro sanitário e antigo incinerador de resíduos sólidos de Ribeirão Preto, SP. 132 f. Relatório Científico Final apresentado à Fundação de Amparo e Auxílio à Pesquisa de São Paulo (FAPESP) no programa de apoio a Jovem Pesquisador, realizado junto ao Departamento de Enfermagem Materno-Infantil e Saúde Pública. Processo FAPESP No: 02/11831-6. 2005.

SEGURA-MUÑOZ, S. I.; BÓCIO, A.; TREVILATO, T. M. B., TAKAYANAGUI, A. M. M.; DOMINGO, J. L. Metal concentrations in soil in the vicinity of a municipal solid waste landfill with a deactivated medical waste incineration plant, Ribeirão Preto, Brazil. Bull Environ. Contam. Toxicol., v. 73, p. 575-582, 2004.

SEGURA-MUÑOZ, S. I.; OLIVEIRA, A. S.; NIKAIDO, M.; TREVILATO, T. M. B.; BOCIO, A.; TAKAYANAGUI, A. M. M.; DOMINGO, J. L. Metal levels in sugar cane (Saccharum spp.) samples from an area under the influence of a municipal landfill and a medical waste treatment system in Brazil. Environ. Int., v. 1, n. 32, p. 52-57, 2006.

SERRA, V.; GROSSI, M.; PIMENTEL, V. Lixão, aterro Controlado e aterro sanitário. Depto. de Química e Bioquímica. UNESP. Botucatu. SP, Brasil. Disponível em: http:// www.laser.com.br/IBB/lixo/aterro/html . Acesso em: 22 out. 1998. 
SERVIÇOS AMBIENTAIS DE RIBEIRÃO PRETO - AMBIENT. Estação de tratamento de esgoto de Ribeirão Preto. Ribeirão Preto, 2005. Disponível em: http://www.ambientbr.com.br. Acesso em: 10 mar. 2005.

SHARMA, V. K.; RHUDY, K. B.; CARGILL, J. C., TACKER, M. E.; VAZQUES, F. G. Cases and solutions: metals and grain size distribution in soil of the middle Rio Grande basin, Texas, USA. Environ. Geology, v. 6, n. 39, p. 698-704, 2000.

SILVA, C. S. Cromo. In: AZEVEDO, F. A.; CHASIN, A. A. M. Metais: gerenciamento de toxicidade. São Paulo: Atheneu, 2003. Cap.2, p.35-65.

SILVA, F. C. Saneamento do ambiente saúde e ambiente. Disponível em: http://www.saudepublica.web.pt/5\%20Saúde\%Ambiental/Ambiente/saneamento_ambiente.ht m. Acesso em: 22 set. 2005.

SILVA, S. V.; PEREIRA, R. A.; PIVELI, R. P.; CRISCUOLO, H. J. Monitoramento da características dos esgotos como instrumento de otimização do processo de lodos ativados e suas implicações. Rev. Bras. Ciências Ambientais, São Paulo, p. 46-59, dez. 2004.

SINGH, K. P.; MOHAN, D.; SINHA, S.; DALWANI, R. Impact assessment of treated/untreated wastewater toxicants discharged by sewage treatment plants on health, a agricultural, and environmental quality in the wastewater disposal area. Chemosphere, India, v. 55, p. 227-255, Oct. 2004.

SNOW, E. T.; COSTA, M. Nickel toxicity and carcinogenesis. In: ROM, W. N. ; RENZETTI JR., A. D. A. D.; LEE, S.; ARCHER, V. E. (Eds.). Environmental and occupational medicine. 2. ed. p. 807-813, 1992.

STAESSEN, J.; ROELS, H.; EMELIANOV, D.; KUZNETSOVA, T.; THIJS, L.; VANGRONS VELD, J.; FAGARD, R. Environmental exposure to cadmium, forearm bone density, and risk of fractures: prospective population study. Public Health and Environmental Exposure to Cadmium (PheeCad) Study Group. Lancet, v. 3, n.353 (9159), p.1140-1144, 1999.

STOEWSAND, G.; ANDERSON, J., BACHE, C.; LISK D. Cadmium deposition and hepatic microsomal activity in mice fed Swiss chard grown on municipal incinerator refuse ash. Sci. Total Environ., v. 94, n. 3, p. 253-259, 1990.

STOVELAND, S.; LESTER, J. N. A study of the factors which influence metal removal in the activated sludge process. Sci. Total Environ., v. 16, p. 37-54, 1980. 
SUNDERMAN JR., F. W.; DINGLE, B.; HOPFER, S. M.; SWIFT, T. Acute nickel toxicity in electroplanting workers who accidently ingested a solution of nickel sulfate and nickel chloride. Am. J. Ind. Med., New York, v. 14, p. 257-266, 1988.

SUNDERMAN JR., F. W.; HOPFER, S. M.; KNIGHT, J. A.; MCcULLY, K. S.; CECUTTI, G. A.; THORNHILI, P. G.; CONWAY, C. M.; PATERNO, S. R.; COSTA, M. Physicochemical characteristics and biological effects of nickel oxides. Carcinogenesis, Oxford, v. 8, p. 305-313, 1987.

SUNDERMAN JR., F. W.; HOPFER, S. M.; SWEENEY, K. R.; MARCUS, A. H.; MOST, B. M.; CREASON, J. Nickel absorption and kinetics in human volunteers. Proc. Natl. Acad. Sci. USA, Washington, v. 191, p. 5-11, 1989.

TAMAKI, S.; FRANKENBERGER JR., W. T. Environmental biochemistry of arsenic. Rev. Environ. Contam. Toxicol., v. 124, p. 79-110, 1992.

TEVES, M. L. U. Lixo urbano contaminação por resíduos de tintas e vernizes. São Paulo: Fundacentro, 2001.

TSUTIYA, M. T. Tecnologias emergentes para disposição final de biossólidos de ETEs. In: CONGRESSO BRASILEIRO DE ENGENHARIA SANITÁRIA E AMBIENTAL, 20, Salvador, maio de 1999. Anais. Rio de Janeiro: ABES, 1999. I-141, p. 61.

UNIVERSIDADE FEDERAL DO RIO DE JANEIRO. Instituto de Física. UFRJ-IF. Disponível em: www.if.ufrj.br/teaching/elem. Acesso: 22 set. 2005.

UNIVERSIDADE DE SÃO PAULO. Centro de Divulgação Científica e Cultural de São Carlos. CDCC. Elementos. Disponível em: http://www.cdcc.sc.usp.br/elementos. Acesso em: 22 set. 2005

US. Agency for Toxic Substances and Disease Registry. ATSDR. Toxicological profile for zinc. Atlanta: ATSDR, 1994. 243p.

Toxicological profile for cadmium. Atlanta: ATSDR, 1997. 347p.

. Toxicological profile for lead. Atlanta: ATSDR, 1999. 587p. 
Toxicologycal profile for arsenic. Atlanta, USA: Agency for Toxic Substances and Disease Registry; U.S. Department of Health and Human Services, 2000.

. Toxicologycal profile for manganese. Atlanta: Agency for Toxic Substances and Disease Registry; U.S. Department of Health and Human Services, 2000.

Toxicological profile for chromium. Syracuse: U.S. Department of Health \& Human Services, 2000.

US. Environmental Protection Agency - EPA. Land application of municipal sludge. Washington: EPA, 1983. 320p.

Land application of sewage sludge. A guide for land applies on the requirement of the Federal standards for the use or disposal of sewage sludge. 40 CFR 503, 1994.

VARIAN. Analytical methods for grafite tube atomizers. Victória, Australia: Varian Australia Pty, 1988.

VIAENE, M.; ROELS, H.; LEENDERS, J.; GOORF, M.; SWERTS, L.; LISON, D.; MASSCHELEIN, R. Cadmium: A possible etiological factor in peripheral polyneuropathy. NeuroToxicol., v. 20, n. 1, p. 7-16, 1999.

VICENT, A. J.; CRITCHLEY, R. F. A review of sewage sludge treatment and disposal in Europe. In: BRUCE, A. (Ed). Sewage sludge stabilization and desinfection. Chichester U.K.: 1984. p. 550-580.

VIEL, R. Estudo do funcionamento da Estação de Tratamento de Esgotos do Campus da Fundação Owaldo Cruz. 1994. 54 f. Dissertação (Mestrado em Saúde Pública) - Faculdade Osvaldo Cruz, Fiocruz, Rio de Janeiro, 1994.

VOEGBORLO, R. B., EL-METHNANI, A. M., ABEDIN, M. Z. Mercury, cadmium and lead content of canned tuna fish. Food Chemistry, v. 67, p. 341-345, 1999.

VON SPERLING, M. Princípios do tratamento biológico de águas residuárias: lodos ativados. Minas Gerais: ABES, 1997.

VOUTSA, D.; ZAXARIADIS, G.; GAANTIDIS, N.; SAMARA, C.; KOUIMTZIS, T. H. Evaluation of municipal and industrial wastewater sludges for agricultural purposes. Fresenius Environ. Bull., v. 5, p. 1-6, 1996. 
WANG, J.; HUANG, C. P.; HERBER, E. A.; POESPONEGORU, I.; POESPONEGORU, H.; TAKIYAMA, L. R. Effects of disolved organic matter and $\mathrm{pH}$ on heavy metal uptake by sludge particulates exemplified by copper (II) and nickel (II): three-variable model. Water Environ. Res., v. 71, p. 139-147, 1999.

WESTPHALEN, C.; NETO, J. C.; CARLI, J. A.; ZIRPOLI, M. R. O. Aplicação do lodo de esgoto na agricultura. In: ROMÉRO, M. A.; PHILIPPI JR., A.; BRUNA, G. C. Panorama ambiental da metrópole de São Paulo. São Paulo: Signus, 2004. p. 117-121, 124-127.

WORLD HEALTH ORGANIZATION. WHO. Manganese. Environmental Health Criteria, 17. International Programme on Chemical Safety. Geneva, 1981. Disponível em: http://www.inchem.org/documents/ehc. Acesso em: 20 dez. 2005.

.Chromium. Environmental Health Criteria, 61. International Programme on Chemical Safety. Geneva, 1988. Disponível em: http://www.inchem.org/documents/ehc. Acesso em: 20 dez. 2005.

Lead-environmental aspects. Environmental Health Criteria, 85. International Programme on Chemical Safety. Geneva, 1989. Disponível em: http://www.inchem.org/documents/ehc. Acesso em: 20 dez. 2005.

Inorganic mercury. Environmental Health Criteria 118. International Programme on Chemical Safety. Geneva, 1991. Disponível em: http://www.inchem.org/documents/ehc. Acesso em: 20 dez. 2005.

. Nickel. Environmental Health Criteria, 108. International Programme on Chemical Safety. Geneva, 1991. Disponível em: http://www.inchem.org/documents/ehc. Acesso em: 20 dez. 2005.

Cadmium. Environmental Health Criteria, 134. International Programme on Chemical Safety. Geneva, 1992. Disponível em: http://www.inchem.org/documents/ehc. Acesso em: 20 dez. 2005.

.Copper. Environmental Health Criteria, 200. International Programme on Chemical Safety. Geneva, 1998. Disponível em: http://www.inchem.org/documents/ehc. Acesso em: 20 dez. 2005.

Arsenic and arsenic compounds. Environmental Health Criteria, 224. International Programme on Chemical Safety. Geneva, 2001. Disponível em: http://www.inchem.org/documents/ehc. Acesso em: 20 dez. 2005. 
WILKINSON, J. M.; HILL, J.; HILLMAN, J. P._The accumulation of potentially toxic elements in edible body tissues of lambs grazing after a single application of sewage sludge. Water Res., v. 37, p. 128-138, 2003.

ZAR, J.H. Biostatistical Analysis. 4. ed. Prentice Hall, Upper Saddle River, New Jersey, USA, 1999. $580 \mathrm{p}$.

ZORPAS, A. A.; KAPETIANOS, E.; ZORPAS, G.A.; KARLIS, P.; VLYSSIDES A.; HARALOMBOUS, I.; LOIZIDOU, M. Compost produced from organic fraction of municipal solid waste primary stabilized sewage sludge and natural zeolite. J. Hazard. Mater., v. 7, p. 149-159, 2000. 